Stanisław Bylina

\title{
Religiousness in the Late Middle Ages
}

Christianity and Traditional Culture in Central and Eastern Europe in the Fourteenth and Fifteenth Centuries

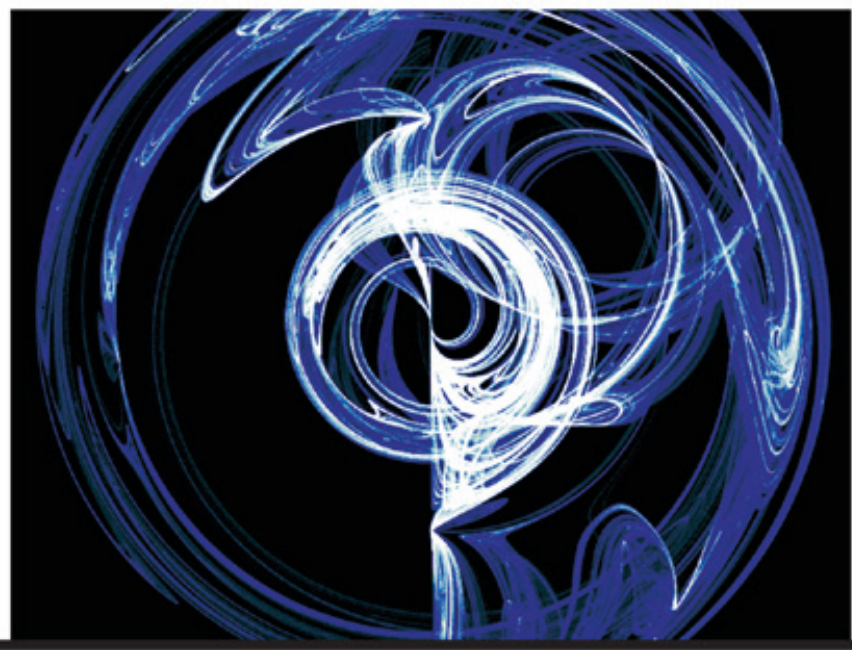


Stanisław Bylina

\section{Religiousness in the Late Middle Ages}

This book is devoted to the religiosity of the medieval Christian masses in Central and Eastern Europe and its relationship with the traditional cultures of that time. Addressing such topics as the common instruction of the three prayers and the Decalogue, "Christian" magic in everyday life, the Marian devotion, and various images of heaven and eternal damnation, the author never loses sight of his main topic: the complex and powerful interaction between medieval folklore and Christianity.

\section{The Author}

Stanislaw Bylina (1936-2017) was Professor of Medieval Studies at the Institute of History of the Polish Academy of Sciences in Warsaw. In 1991 he became that Institute's director. He specialized in medieval Poland, the history of Christianity, and Polish and European culture. 
Religiousness in the Late Middle Ages 


\section{POLISH STUDIES \\ TRANSDISCIPLINARY PERSPECTIVES}

Edited by Krzysztof Zajas / Jarosław Fazan

VOLUME 25 
Stanisław Bylina

\section{Religiousness in the Late Middle Ages}

Christianity and Traditional Culture in Central and Eastern Europe in the Fourteenth and Fifteenth Centuries

Translated by Alex Shannon

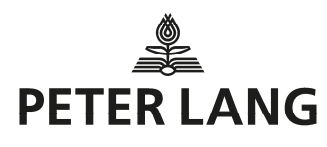




\section{Bibliographic Information published by the Deutsche Nationalbibliothek}

The Deutsche Nationalbibliothek lists this publication in the Deutsche Nationalbibliografie; detailed bibliographic data is available in the internet at http://dnb.d-nb.de.

The Publication is funded by Ministry of Science and Higher Education of the Republic of Poland as a part of the National Programme for the Development of the Humanities. This publication reflects the views only of the authors, and the Ministry cannot be held responsible for any use which may be made of the information contained therein.

Translated by Alex Shannon

Proofread by Chris James

Cover image: Courtesy of Benjamin Ben Chaim

Printed by CPI books GmbH, Leck

ISSN 2191-3293

ISBN 978-3-631-67435-2 (Print)

E-ISBN 978-3-653-06870-2 (E-PDF)

E-ISBN 978-3-631-70844-6 (EPUB)

E-ISBN 978-3-631-70845-3 (MOBI)

DOI $10.3726 / \mathrm{b} 15821$

\section{PETER LANG}
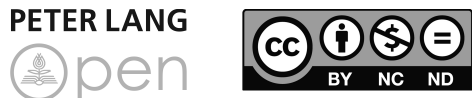

Open Access: This work is licensed under a Creative Commons Attribution Non Commercial No Derivatives 4.0 unported license. To view a copy of this license, visit https://creativecommons.org/licenses/by-nc-nd/4.0/

(c) Stanisław Bylina, 2019

Peter Lang - Berlin · Bern · Bruxelles · New York ·

Oxford $\cdot$ Warszawa $\cdot$ Wien

This publication has been peer reviewed. www.peterlang.com 


\section{Preface}

Historians of medieval Christianity often cite the amusing etymology of a word that emerged from the clerical environment, namely laicus, which in Latin means a layman. According to its etymology, laicus comes from lapis (stone), "for the layman is sluggish and knowledge of letters is strange to him". Even if, in the two centuries before the Reformation, these fanciful origins of the expression had been forgotten, and even though illiteracy, while still widespread, had no doubt gone down, priests still wrung their hands over the religious ignorance of the people under their care. As an on-going and centuries-long process, Christianisation was never an easy undertaking, especially for individuals who saw the need to break away from the routine of parish teaching. One difficult task was to teach all laymen to recite two or three of the basic prayers and a couple of simple texts from the catechism, but a much more challenging mission was to penetrate the faithful's inner beliefs and attitudes.

At the turn of the fifteenth century, Stanisław of Skarbimierz (Stanislaus de Scarbimiria, d. 1431), a Polish theologian, preacher and pastoral theoretician from Krakow, mentioned in his sermons countless examples of what were, in his view, reprehensible religious beliefs, attitudes and practices, often clearly magical in nature, which were shared by laymen, especially simple laymen. Turning to representatives of various estates and professions, including farmers, gardeners, shepherds, fishermen, hunters and innkeepers, he called on them to reject errors (errores) and superstitions as contrary to the proper devotion to God Almighty. These sermons contained material that is extremely interesting and useful to the historian of medieval religiousness. Their value is not diminished by the fact that Stanisław of Skarbimierz was not the original author in this regard. In Western Christianity, similar issues were a matter of debate among theologians participating in the Church's intense pastoral efforts in the fourteenth and fifteenth centuries to cleanse the Christian faith of everything they regarded as foreign content. Did they believe they were succeeding in their mission? Answers to that question depended on the individual's views on the condition of Christianity at that time, which were often pessimistic. Many theologians were convinced that everything around them-the negligence and transgressions of the clergy, and an overall reluctance on the part of laymen to learn and improve-were symptoms of the deep and broad fall of the contemporary Church and contemporary Christianity. Others were not so gloomy in their views of the situation. The Cracovian theologian, convinced of the need to correct the Christian from 
within, did not hide his doubts and feelings of helplessness. He claimed that folk religiousness contained an infinite number of errors, so many in fact that a single university master, indeed all of the world's scholars, would not be able to describe them.

Stanisław of Skarbimierz was aware of the resistance that "errors and superstitions" put up against religious instruction in churches. Along with other representatives of the scholarly clergy, he was a witness to the late stage of the confrontation between the widely adopted and confessed Christian faith and the still living world of tradition and magic that had been handed down from generation to generation; that is, with the heritage of the ancient, pre-Christian past. Today, we have no doubt that that heritage did not signify the continuing worship of ancient gods, who left behind only the slightest trace in the collective memory, but rather the persistence of archaic concepts of the sacred, man's relationship to nature and to the supernatural world, and thus the persistence of traditional sensitivities and a traditional religious imagination. Most recent studies of the history of Christianity in Central and Eastern Europe describe the complicated nature of this confrontation, which was often antagonistic, but which also manifested itself in a symbiosis of the two religious systems and world views.

This confrontation is an important aspect of my reflections in this work because this book is devoted to the religiousness of the Christian masses and its connections with traditional culture. However, while attempting to keep these connections firmly within the field of view, we cannot turn them into the only object of observation; after all, the matters under examination here must also be viewed against the backdrop of collective religiousness practiced in the broader Western Church. We can thus not ignore the wider and essential currents of devotion or the universal manifestations of religious life.

We must ask the question: what religiousness (and which of its levels) will be under discussion here? Historians addressing these and related issues, which have excited a great deal of interest over the last few decades, usually attempt to answer this question in one definite direction or another. Terminological clarifications are often subjective in nature and are, generally speaking, rarely precise; in this area of investigation, in which different aspects and levels of culture intersect, precise definitions seldom encapsulate an entire phenomenon and thus infrequently work. In the reflections below, as in works by other authors, the terms "folk religion" (referring to a wide range of matters) and "folk devotion" (usually when the topic at hand is religious feelings and their manifestations) are often used. I will distinguish them, when justified, from religiousness and from "mass" piety. These concepts often overlap with one another. Generally speaking, when talking about "mass" religion, we emphasise only how it differs 
from elite religion (religious elites, intellectuals, etc.). The term "mass" religion thus refers to the religion of the Christian masses, though it does not get to the heart of these phenomena or their inspiration. The term folk religion, on the other hand, allows us to include phenomena which involve what might be called a substratum of archaic beliefs, which reveal themselves if only in traditional attitudes, often with motivations involving magic. These beliefs were often present in faith and practices that were formally Christian in that they were connected to Christian devotion, etc. Here, we encounter ceremonies and rituals practiced in everyday life, usually beyond the church walls, and which developed without inspiration or encouragement from church officials. That having been said, it must immediately be added that, if the Church rarely approved of these ceremonies and rituals, it did not always combat them. Here, we are not even talking about the fact that rural priests and vicars, often untrained, sometimes shared the "superstitions" of their parishioners. As mentioned above, it was difficult, even during confession, for individuals standing guard for the purity of the faith and lay devotion, including theologians and clergy of various stripes, to penetrate the faithful's internal attitudes. The fact is that a person could reject the words of a Christian prayer in his or her internal religious needs, but he or she could also recite that prayer out of fear of punishment from angry gods or as magical protection against some threat.

In principle, we do not identify "folk religion", which defines a certain level of religious culture, with peasant religion, though the term does refer above all to peasants in the countryside, particularly in Central and Eastern Europe, which was weakly urbanised and whose population was overwhelmingly engaged in farming of one kind or another. This was a human collective that was no doubt most consistent in preserving ancient traditions. But it is also true that, at the end of the Middle Ages, there was little-in terms of internal attitudes-that distinguished these country folk from the residents of towns, which were also largely agricultural in nature, and of the areas around those towns, who themselves were recent arrivals from the countryside. In addition, it was also the case that traditional attitudes, which found their expression in various kinds of rituals and gestures, were shared by representatives of educated segments of society, as evidenced by, among other things, theological tracts from the fourteenth and fifteenth centuries.

This book deals with matters of religious culture which, to a large degree, many countries in medieval Europe shared. However, I have limited the territorial framework of the book to the central and eastern region of our continent, and, strictly speaking, to countries which belonged to Roman Christianity and which were closely connected to Western Europe. We will thus observe 
phenomena of interest in the lands of Poland, Bohemia, Silesia, Hungary and the Teutonic States adjacent to the Baltic. I do not attempt here to make even the most concise representation of the political, military and diplomatic situations in which these countries found themselves in the fourteenth and fifteenth centuries, although I should mention that, during the fourteenth century, Silesia lost its connection to Poland and became a Bohemian fiefdom, and that in the next century the Teutonic State broke apart, a large part of which, in the second half of the fifteenth century, was joined with the Polish Crown. Church divisions on these lands transpired to be more persistent than political divisions: the large Metropolitan Archdiocese of Gniezno continued to administer territories beyond the Kingdom of Poland, including Silesia and Pomerania, which were however within the borders of the Teutonic State and Brandenburg.

Historical scholarship from recent decades, within which the works of Jerzy Kłoczowski must be considered most prominent, points to common developmental tendencies among the countries of Central and Eastern Europe in the fourteenth and fifteenth centuries, though each country moved at its own pace and rhythm. These tendencies, present in many areas of life, expressed themselves in a common growth-with Bohemia playing a leading role until the beginning of the fifteenth century-in church structures and institutions (parish networks, churches, monasteries and cloisters, schools of various kinds, lay/religious corporations), and in the development of various aspects of religious life and religious culture. In many of these areas, and more generally in terms of the overall level of civilization it achieved, Bohemia was the undoubted leader in the region, particularly during the rule of the last two Luxembourgian kings, Charles IV King of Bohemia (1346-1378) and Emperor (from 1355), and his son Wenceslaus IV (1378-1419). In the second half of the fourteenth century, Prague, the wonderful capital of the Kingdom of Bohemia, was not only the largest city in Central and Eastern Europe (with its 35-40,000 residents, it easily surpassed Gdansk, Wrocław, Krakow and Torun), but it was also the region's greatest and liveliest centre of church life. The Hussite Revolution in Bohemia, which began in 1419, and the lengthy wars with foreign Catholic intervention, caused great destruction and severely interrupted Bohemia's development. As a radical movement to reform Christianity, tied in significant ways to national and social issues as well, Hussitism carried out such an immense revolution in the field of religious devotion, in how the faithful participated in that devotion, in the quality of religious life, and in the collective religious mentality and imagination, that-for the historian examining the matters under discussion here-it becomes impossible to talk about events that took place in "heretical" Bohemia and, at the same time, events in other countries. This is particularly true when it 
involves religiousness in the 1420s and 1430s as a result of Taboritism, the most radical current within the Hussite movement. I attempt to describe this peculiar kind of religiousness in another publication. Such an approach does not seem expedient in the context of the Utraquists, whose name is associated with communion under both kinds (sub utraque speciae) for laymen, which was a central part of their program. Particularly in the second half of the fifteenth century, despite prominent distinctions and real differences, which were not merely liturgical, the Utraquists resembled the Catholics.

When discussing Central and Eastern Europe as a whole, it is worth noting that this territory, despite shared developmental symptoms in the fourteenth and fifteenth centuries, remained on the periphery of Western Christianity. This peripheral quality refers not only to the geographical location of these countries, which applies to Scandinavia to an even greater degree, but also to their civilizational delay relative to countries in the West. This can be referred to as "younger Europe," or "younger Christianity," which was introduced into Bohemia, Poland and Hungary only in the tenth and eleventh centuries. The consequences and manifestations of this delay, beyond causes related to population density, included weak church structures in large areas of Central and Eastern Europe. The contrasts in this regard are conspicuous; they are probably greater here than in the West in this same time period, although it is also the case that significant disproportions also characterised the levels of Christianisation in the countries of "old Christianity". In the first chapter of this book, the main topic is significant reflections on the conditions and possibilities of the faithful's participation in religious devotion as carried out in churches. Christianity's delay must have also been tied to the vitality of local traditional folk cultures carried over from pre-Christian times. Another consequence of this delay, one which still seemed to be current in the fourteenth and fifteenth centuries, was the aversion that the national Churches felt towards these cultures, at least the reserve with which they treated them, as remnants of ancient paganism.

In the two centuries before the Reformation, despite their peripheral character, the countries of Central and Eastern Europe were active participants in the life of the Roman Catholic Church and the overall process of Christianisation. With varying degrees of delay, different trends in religious life and devotion, along with new forms of ceremony, penetrated Central and Eastern Europeoften directly from Germany or through intermediaries. Therefore, not surprisingly, we are able to detect many shared phenomena and many similarities in the sphere of collective religiousness. The common Indo-European heritage was a source of a durable universalism in traditional culture, although it did not characterise every country. Given this situation, the latest scholarship in the 
field of historical anthropology and ethnography attests to the vitality of various autonomous versions of these cultures. Through an examination of Bohemian and Polish sources on the traditional culture of the Slavic world, I will attempt to rediscover this autonomy, which was limited and faded through time. Often, reference will have to be made to evidence of folklore as recorded by ethnographers from the nineteenth and twentieth centuries, which provides historians with a wealth of useful material, although it requires considered selection.

This book is not a systematic treatment of the topic suggested by its title, although I have endeavoured to cover all of the basic ground. There are large gaps in this work arising from either a shortage of source material (medievalists whose focus is the history of Central and Eastern Europe have significantly fewer possibilities in this regard than those whose focus is the West), or from the current state of scholarship. While moving through the text, the reader will have an opportunity to understand the great significance that medieval sermons have on our ability to retrace age-old beliefs, ceremonies, and customs. However, many hand-written collections of Bohemian, Silesian, Polish and Hungarian sermons (particularly parish sermons intended for popular audiences) have not yet been thoroughly researched from the perspective of the topics contained in this book. Entire teams of scholars would be required to cover these gaps.

In my reflections on late Middle Age folk religiousness in our part of the continent, I refer relatively often to the Bohemian and Polish realities, a decision made in large part due to the state of scholarship in this regard and to my interests. But here, too, there remain many unrecorded aspects of the history of mass religiousness. Many issues, sometimes of primary significance, are still waiting to be researched.

This work was written a dozen or so years ago, and its content reflects the state of scholarship at that time, especially in light of the fact that it is based more on secondary works than on primary sources. A "modernisation" of the footnotes (most often of those referring to original source material, and less often of those referring to secondary works) would not be the proper procedure here. I have thus added a section under the title "bibliographic information" that focuses above all on works published in recent years; I leave it to the reader to assess, in light of these works, what can be seen more clearly or presented in a different way. A few relatively old works not cited in the footnotes are also included there. 


\section{Contents}

1 The Catechesis of the Population ..................................................... 13

To Church on Sunday .............................................................................. 15

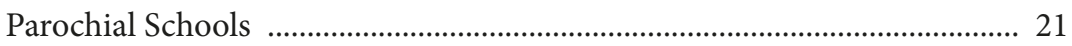

Whom Did Preachers Teach? ........................................................................... 23

The Common Catechesis: Three Prayers and the Decalogue ....................... 25

The Image in Service of the Word .................................................................. 30

Instructional Imbalance ............................................................................. 31

2 Attitudes to the Sacred .......................................................................... 35

The Duties of Good Christians ................................................................ 35

Prayer and Hymns in Church ......................................................................... 38

Prayers of Petition, Prayers of Thanksgiving ................................................. 40

The Repetition of Prayers ................................................................................... 44

The Prayerful Gesture .................................................................................. 46

To See and Be Close ............................................................................ 47

Penetration by the Secular ............................................................................ 52

Blasphemers, Sceptics and Non-Believers ...................................................... 54

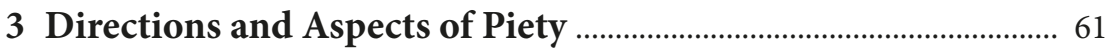

The Path to Christ ................................................................................................. 61

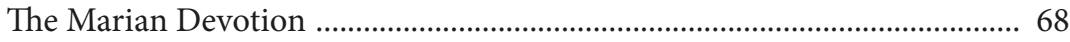

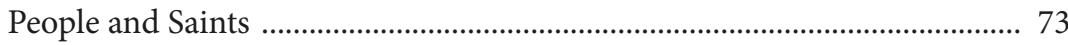

4 Folklore under the Influence of Christianity ……………….......... 83

The Church and Folk Tradition .................................................................... 83

Beyond the Influence of Christianity .......................................................... 87 
The Content of Annual Rites ........................................................................ 88

"Christian" Magic in Everyday Life .................................................................. 91

Magical Words and Texts ................................................................................... 95

Divination ....................................................................................... 100

5 Christianity under the Influence of Folklore ............................... 103

The Natural Environment: Older and Newer Beliefs ................................... 104

The Folklorisation of the Saints: Evidence from Syllabic Verse

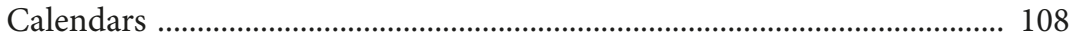

The Sacred among People ...................................................................................... 111

The People's Messiahs ..................................................................................... 113

6 The Living and the Dead ................................................................... 117

Fear of Death ............................................................................................. 117

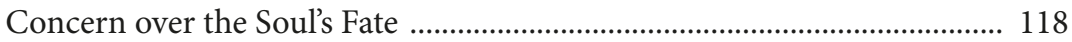

Traditional and Christian Beliefs ................................................................ 123

Categories of the Dead ............................................................................... 128

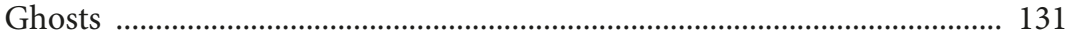

7 Imagination and the Afterlife ........................................................ 135

Imagining Heaven - Paradise ......................................................................... 136

Visions of Eternal Damnation ........................................................................ 142

"The Third Place" ………………………………………………………..... 150

Final Comments ................................................................................ 159

Bibliographic Information .............................................................. 165

Index 


\section{The Catechesis of the Population}

Let us retreat for a brief moment to the era that preceded the Late Middle Ages. In so doing, we might notice that some historians who have researched the Christianisation of Central and Eastern European societies as a continuous process, unfolding over centuries, estimate that pagan belief systems expired in the twelfth century, at the latest. The eminent Polish medievalist Henryk Łowmiański has asserted that the period in which the seeds of Christianity were first planted in the Slavic lands-a period that closed by the late twelfth century-was marked by: "the full Christianisation, in principle, of wealthy and powerful members of society, of knights, and of medieval burghers", and that Christianity, "surely penetrated deep into the ranks of the peasantry" as well. ${ }^{1}$ These assertions are worthy of a certain scepticism, and the body of contravening evidence contains decisions made at Polish synods in the twelfth century regarding obligatory attendance at Sunday and holiday masses, decisions which by no means applied to the entire adult population, but rather only to the representatives of small settlements. Quite clearly, synod decision makers were aware of conditions that prevented the broader population from participating in religious worship, conditions which were, it would seem, not significantly better in other parts of Central and Eastern Europe. Of course, the very notion of "full Christianisation", a rather unfortunate term used to describe what in fact was a never-ending process, can and should be the subject of debate.

I raise the issue of how we might evaluate the state of Christianisation in Central and Eastern Europe in the High Middle Ages because it provides a starting point for observations in later centuries, through to the end of the Middle Ages, when, as is often argued, the "processes of Christianisation everywhere ran deeper and broader, in the sense that they reached the widest extent of the rural population."2 Doubtlessly this is a statement that contains some serious arguments, but it is also one that emphasises the extent to which the Christian religion, in this period, succeeded in taking root in local soils over the extent to which it failed.

At the same time, there is no shortage of scholars who express scepticism in this regard, who highlight the conspicuous superficiality of the Christianisation

1 H. Łowmiański, Religia Słowian i jej upadek (w. VI-XII) (Warsaw 1979).

2 J. Kłoczowski, "L'Essor de l'Europe du Centre-Est," in Les XIVe et XVe siècles, crises et genèses (Paris 1996), $503 \mathrm{ff}$. 
of societies in this region at the end of the Middle Ages, and who also turn their attention to Bohemia, in broad civilizational terms, before the Hussite Revolution. According to the famous Czech historian Františk Šmahel, Christianisation in the fourteenth century, during the rule of Charles IV of the Luxembourg dynasty, encompassed Bohemian lands in their entirety, though it was met almost everywhere in Bohemia (outside of the social and religious elites, of course) by religious knowledge that was, generally speaking, crude and faint, and by resistance from within traditional agrarian culture. ${ }^{3}$ At this point, it would be appropriate to point out that other areas of Central and Eastern European, areas that remained behind the Bohemians, were also marked by this condition.

We are thus faced with a variety of opinions on these matters, as is often the case when global judgments are made that attempt to explain very different and particular situations. Of course, it is essential that we take into consideration disparities between individual countries and regions, and the lands that belong to them, in various levels of advancement. When estimating the level of Christianisation in a broader population, we must always keep in mind differences in the level of religious knowledge and awareness among, on the one hand, residents of cities (large cities in particular) and, on the other hand, residents of towns and villages. If, as some believe, these differences were great, and if it is true that villagers were consistently poorly prepared in elementary catechesis, then we would need to formulate generalisations about Christianisation in a way that is very complex.

At the same time, we should not forget that even in Western Europe, where countries and provinces were marked by a high level of Christianisation among the broader population, there existed regions populated by common people with very low levels of religious knowledge. One scholar, who examined the results of the missionary activities of Wincenty Ferrar (d. 1419), the famous, charismatic Dominican missionary, pointed out that in one town in Brittany, it was only as a result of Ferrar's work that the local faithful "learned Pater noster, Credo, to make the sign of the cross, and to use the name of God." 4 What we have here is not an example of an exceptionally backward settlement, because the missionary was himself convinced that one could demand of the common person, beyond

3 F. Šmahel, "Stärker als der Glaube. Magie, Aberglaube und Zauber in der Epoche des Hussitismus," Bohemia 32, No. 2 (1991), 316 ff; see also J. Macek, "Víra a náboženství v jagellonském věku," Studia Comeniana et Historica 19 (1989), 6 ff.

4 P. T. Dobrowolski, Wincenty Ferrer, kaznodzieja ludowy póznego średniowiecza (Warsaw 1996), p. 135. 
the above-mentioned skills, only a basic knowledge of the Decalogue: "This is the knowledge of people who live from their labour." German lands, closer to Central and Eastern Europe, were characterised at the end of the Middle Ages by a relatively high level of religious knowledge in the middle lower social strata, although-as is often the case-highly optimistic judgments are in need of certain adjustments.

\section{To Church on Sunday}

This basic problem is tied to the extent to which it was possible for all residents living in the various parts of Central and Eastern Europe to participate in Church instruction. Although the opinion which says that, in the Late Middle Ages, "the faithful existed only as parishioners," is somewhat an exaggeration, there is no doubt that the parish church everywhere was still the fundamental centre of the priesthood, of the duties involved in religious practice, and of the main forms of the faithful's religious life. In the great majority of the rural settlements that found themselves beyond the reach of the pastoral activities of (most importantly) the Franciscans and the Dominicans, these churches were the only hubs of religious teaching. Let us recall that people's obligation to attend Sunday mass in their own parish had been imposed much earlier, which no doubt served to integrate the residents of a particular area around their church. The pastoral provisions of the Fourth Council of the Lateran (1215), which ordered, among other things, that people must go to Easter confession in their own parish, and which, in the face of barriers and resistance of various kinds, were implemented in Central and Eastern Europe only after long delays, nonetheless tightened the bonds between parishioners and their church.

Many factors helped determine the character of these bonds, among the most significant of which was, quite obviously, parish size. In the case of a parish made up of many different settlements, which was typical for much of Central and Eastern Europe, the great distance from home to church often hindered residents from participating systematically in Sunday or holiday masses. It would be difficult to offer a global judgment that could encompass the situation in all of Central and Eastern Europe, but for many inhabitants of these lands, it was certainly more difficult to gain access to the parish church than it was for people living in the countries of Western Europe. In any case, nowhere was it like the situation in the northern regions of Scandinavia (Sweden and Finland), where people

5 J. Toussaert, Le sentiment religieux en Flandre à la fin du Moyen Age (Paris 1963), p. 61. 
lived a great distance from the nearest church and managed to attend mass only a couple of times a year, on the most important Church holidays, during which they spent two nights in specially prepared hospices.

If we accept that small parishes created the best conditions for permanent contact with the church for the faithful, although we must also take into consideration the condition of roads and, more generally, topographical and climatic conditions, along with many other factors, there is no doubt in this regard that the inhabitants of Bohemian lands enjoyed a privileged position, given that in the fourteenth century, the size of the average parish in Bohemia did not exceed about twenty square kilometres, which was not much larger than comparable parishes in the well-developed lands of Western Europe. However, we can apply the resulting conclusions about the (generally speaking) good conditions for the Christianisation of Bohemia only to the period before the Hussite revolution, which caused long-term damage to traditional church structures and, more importantly, led to the extermination or the dispersion of priests. Later, in the second half of the fifteenth century, parish structures in both Churches-the Catholic and Utraquist-were rebuilt slowly and with great difficulty. The situation was better in Moravia, where the Hussite movement was relatively weak and old churches survived.

At the turn of the fifteenth century, parishes not much larger than those in Bohemia existed in the Wrocław ${ }^{6}$ diocese in Silesia; such parishes proliferated in that area over the course of the fifteenth century. The situation in Poland and Hungary was worse than in Bohemia, Moravia and Silesia. In Poland, parishes often differed greatly in size, especially comparing the small parishes which surrounded Krakow and the larger parishes in the central and eastern parts of the country. Of course, we must take into consideration the fact that some parishes included territory that was wilderness or was sparsely (if at all) populated. Nevertheless, the average large parish in the Archdiocese of Gniezno or the Diocese of Krakow (around $60 \mathrm{~km}^{2}$ ) suggests that we need to examine the alleged ease with which the faithful had access to their church, particularly in unfavourable winter conditions or during spring floods, when it was difficult to travel by road.

6 Translator's note: Many of the towns and cities mentioned by Professor Bylina are places that have changed names over the centuries, depending on, for example, whether they were governed by Poles or Germans. Wrocław/Breslau and Kwidzyn/Marienwerder are two such examples. As Professor Bylina consistently used Polish names in his original text, I have done the same in this translation. 
The disproportions in parish size are conspicuous in two Hungarian archbishoprics: Esztergom and Kalocsa. In the Teutonic State, the favourable situation in the densely populated Bishopric of Pomesania, with its seat in Kwidzyn, where the average parish consisted of two to three settlements, differed greatly from the neglected regions of the Diocese of Samland, in which a parish could contain several dozen (or more) settlements, and in which the distance to a church would often be great.

In principle, the density of a parish network was tied to the population density of a particular area, or its level of urbanisation. In reality, many different factors played a role in this regard. Of course, one extremely important condition involved how much initiative wealthy and powerful church founders took and how well that church and its parish priests could be maintained. Generally speaking, while new parishes on Polish territories emerged in villages that belonged to wealthy noblemen, they did so with difficulty on lands dominated by petty and poor noblemen (for example in Mazovia) and in areas that were sparsely populated, where tithes paid by residents could not satisfy the material conditions necessary for churches and priests. The following is an accurate statement made by an expert in this field:

The characteristic feature of the average Polish parish, which is evident even today, is its large area, which consisted of several, a dozen, or sometimes even (in older times) a couple of dozen settlements/small villages. Single village parishes, which were typical, for example in France, and which formed a clear ideal that was gradually realised in the Church in the West, appeared along the Oder and Vistula rivers more often in the large and economically powerful villages of German colonisation; the colonists moving into the area naturally wanted to have their own church, and its construction was integrated into their economic plan for the territory. ${ }^{7}$

Undoubtedly, this statement, which refers in particular to the intensively colonised Silesia, assists us in understanding the reality of parishes in this territory. The parish reality was decidedly better in the Teutonic State, what with its German immigrant agricultural population, than was the case on indigenous Prussian lands. We might add that the German inhabitants of tenement villages bore the burden that came with the establishment and functioning of a parish (the Teutonic Order provided for the churches on its territory). Of course, a great deal depended on local conditions and the history of a given area. In that part of Hungary that experienced the ravages of the Mongol invasions, large parishes remained prevalent for a long time. However, in the north of the country, the colonising process

7 J. Kłoczowski, Dzieje chrześcijaństwa polskiego, vol. 1 (Paris 1987), p. 82. 
favoured the development of a parish network. In this way, Saxon colonists in Spiš consistently implemented the principle of "one village-one parish."

The comments above on the size and scope of parishes can be useful, indeed essential, in evaluating the Church's mission above all in rural societies. This is because, when we discuss pastoral services provided in cities, including in towns, although we can point to inadequacies and examples of neglect here and there, we do not see cases in which no churches existed at all. In large and mediumsized cities-of course on a scale commensurate with the region of Europe under discussion here-the number of parish churches varies but is always significant. In Wrocław, there were ten parishes; in Krakow and its immediate surroundings, there were eleven parishes; and in the largest urban centre of Central and Eastern Europe, namely Prague, there were forty-four parishes. There is no doubt that such a large number of parish churches in the cities ensured that all residents enjoyed the opportunity to participate in religious services.

This so-called parish coercion, which tied the faithful to their own church and which applied in practice mainly to urban dwellers, could not overshadow the role played by Franciscans and Dominicans in the religious life of townspeople. Members of these orders began to settle in Central and Eastern Europe as early as the third decade of the thirteenth century; that is, not long after they did so in the West. Both mendicant orders, regardless of their powerful ties with the courts of magnates and princes, exhibited great pastoral ambition among the local population, which of course involved not only the art of preaching, which they had, generally speaking, mastered better than members of the parish clergy, but also on the initiatives they took to organise new forms of devotion, to propagate new cults, etc. In the hands of the mendicant brothers, such skills served to attract the faithful to their churches, a fact that is all the more worth mentioning given that, in the two hundred years between the beginning of the fourteenth century and the end of the fifteenth century, the number of Franciscan and Dominican monasteries in Poland and Hungary grew dramatically; in Poland, the number of monastic houses nearly tripled, and in Hungary they doubled. However, the mendicant orders generally avoided establishing their houses in the kind of small towns (oppida) that were very typical of the kind of urbanisation taking place in both countries in the Late Middle Ages. In those settlements that "were no longer villages but not yet cities," one Hungarian historian claimed that Dominican monasteries were absent and Franciscan monasteries were rare. ${ }^{8}$

8 E. Fügedi, "La transformation des villes et les ordres mendiants en Hongrie," Annales. Économies, Sociétés, Civilisations 25, No. 4 (1970), p. 985. 
In Bohemia, even after intensive expansion by both orders in the thirteenth century, the growth in the number of monasteries continued into the next century, until the Hussite Revolution put a dramatic end to their ambitions. Those monasteries that later managed to rebuild struggled to survive.

In the second half of the fifteenth century, Franciscan Observants played a very important role in the Christianisation of the inhabitants of towns and cities, and an essential role in areas around towns and cities; unlike their unreformed brothers, who kept their houses inter muros, these Franciscans were eager to settle beyond the city walls. While Polish Observants, known in Poland as Bernardines, devoted themselves to missionary work in and around towns and cities, members of that community in Hungary also penetrated the peasant and noble environments. With the Turkish threat, which was strongly felt in Hungary in the second half of the fifteenth century, Franciscan Observants connected piety and devotion with an element of patriotism seasoned with hostility toward the pagans.

Let us return to parish life. Urban parish churches were normally able to attract sufficient clergy; indeed, in the case of large cities, we can see an excess of clergy, particularly when it involved the lower clergy, whose main work involved mass intentions. ${ }^{9}$ During the rule of the last two Luxembourgians, Prague distinguished itself in this regard, and the large churches in Wrocław and Krakow had at their disposal a large pastoral operation. Rural parishes found themselves in different circumstances. An excellent source for this topic (and for many other issues in the field of church life), namely the protocols of the visitations of the Prague archdeaconry from 1379 to $1382,{ }^{10}$ gives us a reasonably detailed picture of each of the visited parishes. From the testimony given by local clergy and selected parishioners in front of the archdeacon, a high-ranking church official, we learn, among other things, that in no small number of cases the parish priest was often absent, which created a disadvantageous situation particularly when parish priests, carrying out various functions outside their own parish, had no substitute, or when an unfamiliar priest would sporadically visit from a distant village to carry out pastoral duties. However, taken as a whole, the well-known,

9 Translator's note: The Polish word intencja (which is accurately and meaningfully translated as "intention") refers to prayer or a mass that is directed at a particular purpose or is offered in the name of a person or persons (living or dead).

10 Protocollum visitationis archidiaconatus Pragensis, annis 1379-1382 per Paulum de Janowicz, archidiaconum Pragensem factae, first edition, eds. Ivan Hlaváček and Zdeňka Hledíková (Prague 1973). 
late-Middle-Ages phenomenon of the absent cleric was, in pre-Hussite Bohemia, not as harmful as it was in certain lands in the West. In addition, the fifteenthcentury protocols of visitations to the Diocese of Geneva ${ }^{11}$ paint a picture of undoubtedly serious religious neglect of the faithful by the clergy. The situation in Poland appears to have been generally satisfactory, although the number of priests in any particular parish-obviously we are not talking about towns and cities here-was usually one or two, and in many areas a single priest was the rule. Rare instances of a vacancy at a parish church were usually the result of insufficient pay.

With the possible exception of Bohemia before the revolution, there were neglected regions in every country of Central and Eastern Europe, in which people were deprived of the opportunity to have systematic contact with a parish church. A more precise examination of these regions, beyond assertions that can be made based on the density of parish networks, is made difficult by, among other things, a lack of sources that compare with the above-mentioned Bohemian visitation protocols. Resolutions approved by the diocesan synods, to which we usually refer when we discuss these and similar issues, very rarely mention the matter of the faithful's participation in the Sunday mass. Neither those few instances when the matter was raised by the synods, nor visitation questionnaires (that is, forms containing a set of questions asked by the bishop or his delegate during a parish visit) indicate concern on the part of church authorities about the existing situation. But regarding rural parishes, we cannot conclude from the silence in these sources that participation in obligatory church practices was prevalent among the broader population. We can, however, accept the notion that higher church authorities were aware of local conditions and did not expect universal or systematic participation in the Sunday mass in places where the barriers between home and church were too great. That having been said, the matter of the significant size of certain parishes emerged repeatedly. In Prussia as late as the fourteenth century, the rules tying priests in the Diocese of Samland to their churches were relaxed in cases where they lived far from those churches. Around a century later, in the Diocese of Płock, efforts were made to solve the problem of priests having to travel long distances to parishes which had requested that the sacraments be performed for the sick. Finally, in evaluating the faithful's participation in divine worship, statements made by witnesses during a hearing before a church court in Włocławek, in the case of a peasant

11 L. Binz, Vie religieuse et réforme ecclésiastique dans le diocèse de Genève pendant le Grand Schisme et la crise conciliaire (1378-1450), vol. 1 (Geneva 1973), $391 \mathrm{ff}$. 
suspected of heresy, are telling. According to individuals who submitted testimony on the village resident's behalf, he went to confession, took communion, and attended church services "to the extent of his ability" (pro posse suo). ${ }^{12}$ This expression reveals a truth about parish life that was certainly not exceptional, either in the Diocese of Włocławek or in the Kujawy region.

\section{Parochial Schools}

Before we take up the subject of the catechesis and evangelising of the faithful in parish churches, let us devote some time to instruction provided in parochial schools. Throughout all of western Christianity, these schools' task was to implement the resolutions of the above-mentioned Fourth Council of the Lateran. In the territories under examination here, the priests responsible for the functioning of schools often focused on preparing groups of peasants to assist in the church liturgy, and particularly on developing choral singing skills to add splendour to the religious service. In the collective opinion, school instruction was synonymous with singing. The parochial school program included the basic elements of the catechism (including prayer texts), which was the case everywhere in western Christianity, although not everywhere was equal emphasis placed on this area of instruction. Let us take as an example the content of instruction in France at the beginning of the sixteenth century, according to which children who did not know the basic prayers had to attend school until they finally learned them. ${ }^{13}$

But if we reflect on the role of the parish church and its place in the instruction of the catechism, we must also remember that, in the villages and small towns of Poland and Bohemia, school instruction, despite its mass presence in both countries, could only reach a very small percentage of youth. Many factors were involved here, among which is one described above, namely the great distances between certain settlements and churches in multi-village parishes.

Another, highly significant factor involved the fact that school instruction was simply of little use in the collective life of peasant villages and small towns. Doubtlessly many peasant parents dreamed of a career in the church for their sons, a preliminary condition for which was passage through a parochial school. Often, such dreams (Jan Hus mentions them in reference to the Bohemian countryside) were in fact part of the clerical path taken by a village peasant. These

12 Acta capitulorum nec non indicorum ecclesiasticorum selecta, ed. B. Ulanowski, vol. 3, part 1, No. 633(Krakow 1908).

13 H. Martin, Le métier de prédicateur en France septentrionale à la fin du Moyen Age, 1350-1520 (Paris 1988), p. 361, footnote 26. 
dreams did sometimes come true, and a significant number of peasant sons among university students at the time, including at the university in Krakow in the fifteenth century, would seem to indicate that a clerical path was entirely realistic. That having been said, such a path was trodden only by a very small percentage of the rural youth.

Concerned about the level of instruction in parochial schools, in which a part of the future clergy received their first training, Polish diocesan authorities in the fifteenth century established suitable requirements and opposed excessive numbers of pupils. We might also note that providing pupils with a defined body of knowledge and skills was only one of the schools' goals, and it was not necessarily regarded as the most important. Polish synodal statutes from the fifteenth century state that boys could be accepted into schools for the study of "customs and writing," and as far as the teacher was concerned, "he teaches parish sons customs, virtues, and knowledge." ${ }^{14}$ School programs thus emphasised the inculcation of morality and Christian attitudes over other skills.

The scant information we have about instruction given at rural parochial schools in Poland in the Late Middle Ages indicates that, alongside reading and writing, the singing of church hymns, and the basics of the liturgical calendar, schools also taught pupils to say three basic prayers (the Lord's Prayer, the Hail Mary, and the Apostles' Creed), the Decalogue, and other catechetical formulae. This program does not appear to have been very different from those implemented in other countries in Central and Eastern Europe, but it was thinner, less detailed, and no doubt easier to command than the program that was required in urban parish churches. An incomparably smaller role was played by the study of Latin, whose basis a small number of older pupils would begin to learn in preparation for further education and eventual entry into the clerical estate. In the parochial schools of the Teutonic State, the catechism was taught in German, but also in the Prussian and Polish languages. In the area of catechismal knowledge, pupils at rural schools essentially learned little more than what was-or, at least, was supposed to be-inculcated into the minds of adults at church, though it is perhaps true that the "young boys" (parvuli pueri) referred to in the above-mentioned fifteenth-century source remembered these lessons more easily and with greater permanency.

14 See, for example, "Ordinationes sub regimine Petri de Bnin, episcopi, anno 1487 editae," in Statuta synodalia dioecesis Wladislaviensis et Pomeraniae, ed. Z. Chodyński (Warsaw 1980), p. 25. 


\section{Whom Did Preachers Teach?}

According to a principle accepted throughout the entire Church, it was the Bishop, at diocese level, who imposed teaching duties within the parish on the parish priest. Essentially, a distinction was drawn between, on the one hand, teaching resources and information that fell under the category of exhortatio and, on the other hand, sermons strictly defined, which were understood above all as a kind of lecture on (or, perhaps, clarification of) the Gospel or any other Bible reading that the faithful might hear on any given Sunday or Church holiday. Preaching, the delivery of sermons intended for the people, developed intensely in the countries under discussion over the last two centuries of the Middle Ages, though the rhythm of its development varied from place to place. In Poland, only in the second half of the fourteenth century did preaching become a common phenomenon at churches in large cities. Previously, when bishops ordered priests to deliver a sermon, they did so on conditional terms: "If there are capable priests, then let them lecture on the Gospel." There was a sense that the church lacked adequately trained priests who could get permission to "explain the Gospel in the people's language." The situation was somewhat better in Bohemia, although in both countries preaching developed intensively only as a result of the establishment of universities, in particular in Prague in 1348 and in Krakow, in which case the date it was formally established, 1364, is not as important as the date of its resumption, 1400. Before that, Dominicans and Franciscans in both countries had supported the poorly prepared diocesan clerics by delivering sermons in the cathedrals and other churches in large cities. The preaching done by mendicant monks enjoyed great success, then and later, among the local population, because these sermons were well prepared, lively and attractive; they were interwoven with exempla (illustrative anecdotes) that inspired the listeners' feelings and imaginations. Over time, they were turned into sermon collections ("postils") for use on Sundays and church holidays, having been most often drawn from the most popular collections put together in the West.

In the late pre-Hussite era in Bohemia, preaching to the people flourished particularly in the kingdom's capital. Countless sermons were delivered every Sunday and on every church holiday, and popular sermons spoke the Word of God on weekdays. A good example in this regard was given by the first Archbishop of Prague, Arnošt of Pardubice (d. 1364), a worthy and wise dignitary of the Church, and one who was not afraid to deliver his sermons in the Czech language. In Prague, reformist sermons had an enormous influence on the faithful; three representative, and yet outstanding, examples in this context were Konrad von Waldhausen (d. 1369), who delivered hugely popular penitential 
sermons in German; Jan Milíč z Kroměříže (d. 1374), a Czech mystic, missionary, and an advocate of the renewal of Christianity through a return to its sources, namely the Holy Scripture and the sacraments; and finally, at the beginning of the fifteenth century, master of the University of Prague, Jan Hus (d. 1415), a passionate critic of the prevailing state of Christianity, and especially of the clergy's ethical misbehaviour. An entire generation of preachers came of age in Prague in the reformist spirit, a great part of which influenced the later Hussite movement as ideologues and exponents. An important role was played in this movement by the Bethlehem Chapel, which was established in Prague at the end of the fourteenth century, and in which reform-minded priests delivered sermons for the people. At the forefront was Jan Hus, who gradually gained a reputation as a good and bold preacher. Such sermons helped reconcile ideological influence over the faithful with goal of a basic religious education, which is a subject to which I will return later.

Somewhat later than in Prague, and in certain cases much later, preaching developed in cities in other Central and Eastern European countries. In the fifteenth century in Krakow, which was significantly smaller than Prague, eighteen sermons were given in Polish every Sunday, and six in German. We see a veritable flood of sermons in Wrocław. A shrewd observer of the prevailing reality, Peter Eschenloer, wrote on this subject in 1460 not without a certain critical irony:

It seems to me that there is no other city in the world in which there would be as many sermons every day as there are in Wrocław-morning and evening, and as many preachers who say more interesting and unusual things that they [the faithful] gladly listen to. ${ }^{15}$

An abundance of sermons was also observed in the smaller cities of Silesia, for example in Legnica; sometimes bishops ordered their number to be limited so that the Word of God would not be overexposed. In Hungary, in the second half of the fifteenth century, a particular role was assigned to Franciscan Observants as preachers and as authors of widely used collections of Sunday and holiday sermons and sermons dedicated to saints. The extensive collection of Latin sermons by Pelbartus of Temesvár and Osvaldo de Lasko from the end of the fifteenth century served as patterns for delivering Hungarian sermons in Pest, in other cities, and deeper in the provinces.

The presence of preachers in villages and towns varied greatly, depending on place and date. In pre-Hussite Bohemia, protocols of the archdeaconry's

15 A. O. Meyer, Studien zur Vorgeschichte der Reformation. Aus schlesischen Quellen (Munich 1903), p. 83. 
visitations provide a record of relatively few transgressions in this area. Occasionally, complaints that the Word of God had not been proclaimed for the people emerged against an ethnic and lingual backdrop; the German population did not always have its preachers and confessors. The situation was much more complicated, especially in the first half of the fourteenth century, on the Prussian lands of the Teutonic State, where priests who understood only German were instructing people - and even hearing confession! — through a translator. Later, a priest arrived who could speak the Prussian language, and who also came from the indigenous people, though preaching in the local language even in the fifteenth century was still not widespread. In Poland, the annalist Jan Długosz was enthusiastic about the prevalence of preaching in the country after the resumption of activity at the University of Krakow, when Polish sermons began, in his words, "to resound not just in the cities, but also throughout the villages of the entire Kingdom." ${ }^{16}$ However, we must treat Długosz's statement regarding rural parishes as a sign of an improved situation particularly in the diocese with which he was most acquainted, namely the Diocese of Krakow. After all, the fact is that graduates of the University of Krakow, who were generally speaking the members of the clergy best prepared to deliver sermons, ventured into the rural parishes only in exceptional cases. Among the reasons that preaching was a rarity in rural churches was the fact that so few sermons had been collected in the national language. Rural priests had to purchase Latin postils (the bishop obliged them to do so), but the problem remained of how to make use of them in the preparation of sermons in the mother tongue. Confronted by this language problem, the rural cleric either performed a task that was very difficult for him (Polish and Czech evidence on this matter can be found in manuscript codices that originate from rural parishes) or he gave up the idea of delivering a sermon and had to be satisfied with a more simple form of instruction. Jan Hus was aware of these problems; he wrote some of his collected sermons in Czech with insufficiently prepared rural priests in mind.

\section{The Common Catechesis: Three Prayers and the Decalogue}

Let us look at the form of religious education of the faithful that either accompanied the sermon or replaced it. What is involved here is a program of general and rudimentary catechesis intended for laymen that church authorities in every

16 Regarding Teutonic Prussia, see Ch. Krollmann, "Eine merkwürdige samländische Urkunde," Altpreussischen Forschungen 11 (1934): pp. 36-37. Regarding Poland, see Joannis Dlugossii Liber beneficiorum dioecesis Cracoviensis, vol. 1 (Krakow 1863), p. 261. 
country treated as one of the priest's most important duties. We read about this program most clearly in decisions handed down by bishops, in resolutions passed by synods, and, from around the middle of the thirteenth century, in church legislation of particular dioceses. Let us begin with orders from a legate of the Holy See, James (archdeacon of Liège), issued at the synod of Wrocław in 1248, which called on priests of every parish to say out loud, in the parish language (in vulgari), the Lord's Prayer and the Apostles' Creed, or to say the Lord's Prayer in Latin and the Apostles' Creed in the parish language, ${ }^{17}$ the reason being, as the legate argued, that there were, in a certain diocese, people a hundred years old who had no idea what they believed. We do not know the exact basis for this opinion, and we do not know to which parish in the Diocese of Wrockaw the legate was referring. But it is significant that, with his order, Archdeacon James introduced into Silesia the kind of minimal program of parish catechesis that had already been implemented in Western Europe. Polish sources allow us to carefully trace modifications of this program; at the end of the thirteenth century, the Archbishop of Gniezno, Jakub Świnka, decided that, on every Sunday of the church calendar during High Mass, after the Creed, the priest was supposed to recite and clarify, using Polish, the Lord's Prayer, the Hail Mary and the Apostles' Creed, and also to recite along with the faithful the text of the Confiteor Kaję się Bogu (Korzę się przed Bogiem). This group of prayers and lessons was supposed to have a place-let us highlight this term-loco sermonis ${ }^{18}$; that is, instead of the sermon.

A similar program of instruction using prayer texts can be found in Bohemia and the Teutonic State in the fourteenth century. Synods in the Diocese of Prague limited such prayers to the Lord's Prayer and the Apostles' Creed, and priests were supposed to recite them, together with the faithful, every Sunday before the sermon. Even before the middle of the fourteenth century (in 1343, to be precise), priests and vicars received a strict order that the texts of basic prayers were to be carefully repeated with the faithful using the language of the people, Czech and German ${ }^{19}$, the goal being to avoid inexact understanding and outright errors. The implementation of this order calling for instruction in the basic

17 Jacobi Archidiaconi Leodiensis, Legati Apostolici Constitutiones in concilio Wratislaviensi anno 1248 editae, in Starodawne prawa polskiego pomniki, A. Z. Helcel, vol. 1 (Warsaw 1856), p. 357.

18 Constitutiones Jacobi Archiepiscopi Gneznensis, in ibid., p. 384.

19 R. Zeleny, Councils and Synods of Prague and their Statues (1343-1361) (Rome 1972), p. 21 (reprint from Appolinaris 45 [1972]). 
prayers and for sermons to be delivered by priests was to be inspected during the bishops' visitations.

Supported by a relative wealth of sources pertaining to this issue, mainly Polish, we can claim that, by the beginning of the fifteenth century, a minimal program of catechesis for the faithful had been established. In principle, the program involved instruction in the three basic prayers, to which was added an element of great importance: the study of the Decalogue. Occasionally, the enumeration of the seven deadly sins was included, along with the seven virtues and the seven acts of mercy. There was occasional mention of the text of Confiteor, which had been taught as early as the thirteenth century. All the way through the late pre-reformation era, this program, established by higher authorities, did not change, at least not greatly, as evidenced by synodal resolutions from throughout the fifteenth century, and by instructions for priests and those conducting parish visitations at the turn of the sixteenth century. Among all of these texts, the one that is most significant to us contains instructions handed down by the bishop of the Diocese of Przemyśl regarding how the faithful were to listen carefully to the priest's teachings. The Latin word used here, praedicatio, did not refer to the sermon itself, but rather to the form of catechesis under discussion here.

Instruction in the Lord's Prayer, the Hail Mary, and the Apostles' Creed was based on their recitation, out loud, by the priest himself or by him along with the faithful, the goal being, of course, that the people would memorise the prayers. Reliable sources in both Polish and Czech mention clearly the recitation of two or three prayers in the parish language. However, in the case of dioceses whose population was ethnically mixed, the term in vulgari could mean more than one language. A statute issued by Wacław, Bishop of Wrocław (1406), ordered priests to teach and clarify for the people the three prayers in the languages used in the area: German and Polish. ${ }^{20}$ Saying the prayers in both languages, which was ordered once again in statutes from 1446, makes it possible that the people would have had an inexact understanding of the prayers' correct versions. Beyond Silesia and the Diocese of Wrocław, church officials in the borderlands of the Kingdom of Poland and the Teutonic State also emphasised the need to teach the faithful in one of their own languages (Polish or German).

In the Teutonic State, instruction in the Lord's Prayer and the Apostles' Creed was obligatory in every parish. However, it often happened that the Prussians found themselves simply repeating the prayer, along with the priest, word for word in German, which they did not understand. In the middle of the fifteenth

20 J. Sawicki, Concilia Poloniae, vol. 10 (Warsaw 1963), pp. 362-363. 
century, one Teutonic priest staying temporarily in the Baltic Sea town of Ragnit gained praise from the locals for the fact that he was able to provide instruction in both German and Prussian: tam in theutonico, quam prutenico. ${ }^{21}$

To some extent, confession offered the parish priest the possibility to oversee the faithful and their knowledge of the basic prayers. According to the principle in synodal resolutions as early as the thirteenth century and mentioned later by bishops, the confessor, convinced that his penitent is a simple person who betrays his ignorance, was to instruct that penitent in the text of the Lord's Prayer and the Apostles' Creed. Obviously direct and individual contact between the priest and parishioners might well have had a powerful impact on their religious education. But is it realistic to think that, in a situation in which the faithful were participating in confession as a collective event, particularly during Easter confession, a priest would be able to put thought into a detailed examination of any particular individual?

As we know, the clergy was responsible for not only the memorisation of the three prayers, but also their explanation, which had to be clear and comprehensible to everyone. Time-tested didactic methods were employed. The Lord's Prayer was discussed according to the order of the petitions in it, and based on the text of the Apostles' Creed, the goal was to present, in an accessible way, the fundamental truths of the Catholic faith. In Bohemia, Tomáš Štítný ze Štítného (d. after 1401), author of religious works intended for laymen, presented what was, in his view, the most simple analysis of the Creed according to the twelve truths of the faith contained in its text. But complete simpletons, who were entirely incapable of remembering the text of the Apostles' Creed, needed only to know how to state that they believed in God and in the Trinity. ${ }^{22}$ Of course, the implementation in actual parish practices of orders issued by church leaders and of guidelines set forth by pastoral theoreticians and authors of religious tracts was itself a distinct problem. A great deal depended on priests and their knowledge and didactic skills, and on the possibility that catechetical instruction, in different environments, would be open to different perceptions.

The number of initiatives taken by those in the pastoral, diocesan and monastic milieus that were intended to instruct the faithful in the Decalogue

21 M. Biskup, "Bermerkungen zum Siedlungsproblem und den Pfarrbezirken in Ordenspreussen im 14.-15. Jhd.," in Die Rolle der Ritterorden in der Christianisierung und Kolonisierung des Ostseegebietes, ed. Z. H. Nowak (Toruń 1983) (Colloquia Torunensia Historica. Ordines Militares, 3).

22 Tomáš Štítný ze Štítného, Knížky šestery o obecných věcech křestanských, ed. K. J. Erben (Prague 1852), p. 12. 
and sometimes, simultaneously, in the basic prayers, was remarkable. On the one hand, as indicated in synodal resolutions, changes were aimed only at getting parishioners to memorise the Ten Commandments in their proper order. On the other hand, a significantly deeper goal was to inculcate in the minds of parishioners the ethical content of the Decalogue, and to teach how the commandments could be applied in real life, how to live in agreement with them, or how one might trespass against them. This goal could be reached through the sermon and through confession. For example, confessors applying the schema of the Ten Commandments (as proposed by, among others, Matthew of Krakow, d. 1410) asked penitents, regarding the First Commandment, about worshipping "idols," demons, and natural forces, and about practicing divination, curses and spells. ${ }^{23}$ Of course, one condition for such a course of action was suitable preparation of priests, who, among other things, rarely understood the beliefs and practices tied to local cultural tradition. Nevertheless, the implementation of the first of the above-mentioned goals was problematic not only in the context of those parishioners who were least prepared to internalise religious texts or who had been neglected in terms of elementary education. After all, when the texts of the Ten Commandments and the Apostles' Creed were written in large Czech letters on the walls of the above-mentioned Bethlehem Chapel, it was of course the education of sufficiently literate people that the writer also had in mind. In later times, when the Bishop of Wrocław Peter Nowak ordered every priest to set up wooden tablets in churches on which were written the Ten Commandments and the three basic prayers, he did so not for the illiterate, but for the faithful, who could improve their knowledge of these texts by studying them.

The greatest difficulties undoubtedly emerged in rural parishes and in other parishes outside city centres, whose residents did not participate in the intensive religious life of their urban counterparts. It was not enough in rural parishes to recite the Ten Commandants along with the priest, or to repeat them, according to the bishops' orders, twice a month or even during every Sunday or holiday mass. Other techniques were thus used that did not require an ability to read, and that facilitated the memorisation of the commandments one after the other. The Decalogue was converted into verse, and the large number of these verses in Poland indicates how popular the method was in drumming texts into the human memory. Franciscan Observants played a special role in carrying out

23 Mateusz z Krakowa, "De modo confitendi," in Materialy do historii teologii średniowiecznej w Polsce, vol. 1: Mateusz z Krakowa, Opuscula theologica dotyczace spowiedzi i komunii, eds. W. Seńko, A. L. Szafrański (Warsaw 1974), p. 306. 
these and other forms of education; they were zealous in their effort to bring the catechesis to people around the cities and villagers close to their monasteries. The Ten Commandments in verse form emerged from Franciscan circles, parts of which were sung with the faithful, who were thus able to acquaint themselves more easily with the text. In the fourteenth and fifteenth centuries, Czech religious authors not connected with the monks recommended that the faithful sing the prayer that was most often used, the Lord's Prayer, no doubt in order to facilitate its memorisation.

At the same time, pictorial representations of the Ten Commandments served not only simple parishioners. The famous "Zehn Geboten Tafel" from the second half of the fifteenth century, which was designed for the faithful of German descent from the wealthy Marienkirche parish in the great Hanseatic city of Danzig, showed examples through both images and text (written on banderols) of God's commandments being carried out, alongside examples of them being broken. Such imagery and text did not so much assist in the memorisation of the commandments as they applied the commandments to the reality of, to a large degree, urban life.

\section{The Image in Service of the Word}

We have not yet looked at the educational role of the image, above all gothic murals-broadly comprehensible to the human eye-in parish and monastic churches. In the fourteenth and fifteenth centuries, they were emphasised in particular by theologians for whom the issue of pastoral care was important. For example, the Krakow scholar Benedykt Hesse (d. 1456) asserted that images were to raise Christ and his agony in the mind of the faithful. An unknown Silesian author of sermons (in 1468) described even more eloquently the educational role of paintings:

Images need to be prepared above all to reduce the ignorance of simple people, who are not able to read the Scriptures, so-with such images, as if with the Scriptures-they might read and master the sacraments of the faith. ${ }^{24}$

In recent and rapidly developing research on mural paintings in Central and Eastern Europe, scholars have emphasised the clear presence in these paintings of "catechetical" agendas designed for laymen viewers, including for members of the lower strata of society. The intention behind such agendas was to present, in the simplest way possible, three of the most basic thematic aspects of the

24 A. Karłowska-Kamzowa, Malarstwo ślaskie 1250-1450 (Wrocław 1979), p. 67. 
Catholic faith: sin, redemption and judgment. To what extent these presentations could be widely understood remains a matter of debate. There is no doubt that paintings with defined themes, which showed, for example, the birth and youth of Jesus, the crucifixion, and the Final Judgment, influenced, each in its own way, feelings and the human imagination. However, even paintings that symbolically described the seven deadly sins and the seven acts of mercy, for example in Olkusz in Małopolska and Levoča in Slovakia, no doubt required explanation and the priest's suitable interpretation. We can say the same about other "catechetical" motifs, which were, after all, not very great in number. At the same time, but beyond certain meagre indications that images were used for instruction, we have no real knowledge of parish practices in this regard. In the end, without minimising the role that murals played as in instrument in religious didactics, we should not overestimate their importance, particularly in the context of the matter under discussion here, namely the transfer to the faithful of basic catechetical knowledge.

\section{Instructional Imbalance}

Given even the particular situation in Bohemia, where in the Hussite era earlier forms of church and religious life were broken, we cannot help but see that, over the approximately two centuries before the Reformation, the Church in Central and Eastern Europe aimed to teach the people the three basic prayers, the Decalogue, and a few other catechetical formulae. The great frequency of orders and implorations issued by church authorities (characteristic particularly of Poland, but to some degree also of other countries) seems to suggest that they were not very effective, and to indicate that the people had sketchy knowledge of religion at best, or that they were permanently ignorant on the issue. Obviously this suggestion cannot be applied equally to all countries, to their various regions, or to every locality in which the Church offered instruction. Above all, it cannot be applied to residents of large cities or the majority of medium-sized cities, where contact with local churches was easy to maintain, and where the level of instruction was generally high. We have already addressed of the role of the mendicant orders in religious education; their influence on burghers' knowledge and awareness of religion was no doubt great. The confraternities, as an enormous factor in the Christianisation of the people in large cities and many medium-sized cities, brought together a large percentage of burghers under their wings; they played an important role in church instruction by establishing strong bonds between their members and the parish church, its altar, and the duties of prayer entrusted to them. As shown by the example of the confraternities 
in Teutonic cities, they participated in several dozen additional masses annually, beyond the Church-wide masses that took place on Sundays and holidays. Undoubtedly, members of the confraternities (not only the largest and most prestigious ones), which above all included elite burghers, knew and understood the basic prayers perfectly well, but it was also often the case that, listening to sermons, they had mastered, even if superficially, the fundamentals of faith as much as the Church expected from any laymen. I would argue that this description of the situation applies, generally speaking, to every one of the larger cities of Central and Eastern Europe.

Due to the lack of broadly-conceived comparative scholarship, any evaluation of the level of catechetical knowledge among rural folk requires a certain restraint. Pre-Hussite Bohemia no doubt distinguished itself favourably compared to other areas under discussion here, which is negated neither by the differences in levels between urban and rural populations noted by historians, nor by examples found in the sources of ignorance among villagers. We see the latter both in various popular writings and in sermons, whose authors did not avoid generalisations in their criticism of representatives of individual social strata. Johlín of Vodňan, an author rich in information and commentary on postils from the beginning of the fifteenth century, thought that a great many simple laymen generally did not know the Apostles' Creed and made mistakes when saying the Lord's Prayer. ${ }^{25}$ Let us refer once again to evidence provided in the extremely valuable protocols of Paul de Janowicz, where we read of complaints issued by the faithful from small rural parishes, or from villages with only a chapel of ease, complaints directed at priests who were either failing to provide instruction on the texts of the Apostles' Creed and the Lord's Prayer, or were doing so only sporadically. Some of those providing testimony connected negligence in the catechesis with the priest's worldly hobbies; according to villagers of Všehrd, their priest liked to go hunting with a net and a sparrow hawk rather than teach the Creed. ${ }^{26}$ But it is difficult to avoid the conclusion that such complaints, which were not numerous but meticulously recorded over the course of a visitation, indicate rather that the condition of religious instruction for rural folk in the large Prague archdeaconry was good. After all, the examples of inadequacy and neglect were perceived and treated as a deviation from the proper course of events.

Around the middle of the fifteenth century, Jan of Rokycany (d. 1471), a prominent pastor and dignitary of the Utraquist Church, recalled in one of his

25 R. Řičan, Johlín z Vodňan, Křižovník kláštera zderazského (Prague 1930), p. 72.

26 Protocollum visitationis archidiaconatus Pragensis, pp. 354-355. 
sermons ${ }^{27}$ the piety of the people when he was young; that is, in the pre-Hussite era. In those days, simple residents of cities and villages commonly knew their prayers and said them at home, morning and evening, and after hearing the church bells peal, they fell to their knees on the streets, paths and fields. This recollection, which reflects a sense that the quality of religious life in the exhausted country had fallen, and which indicates the usual longing for times gone by, accurately reflects the circumstances surrounding the Christianisation of rural people in Bohemia before the Hussite revolution. However, the question remains whether the religious illiteracy of pre-revolutionary generations was as acute as historians have often estimated. About a hundred years ago, the Czech historian Zikmund Winter described the deplorable state of Christianity in a country in which peasants lived without religion, and in which they did not know the Lord's Prayer; they did not participate in rituals, and they had not partaken of the sacraments for years because the churches were destroyed and there was a shortage of priests who would either reside permanently in the parishes or at least visit them. Relatively recently, Josef Macek came to essentially the same conclusions. In his view, just before the Reformation, mainly the rural population but also noblemen and burghers exhibited far-reaching neglect in basic religious knowledge.

In Poland, where religious life before the Reformation did not experience great upheaval or breakdown, church bells pealed (as they had in pre-Hussite Bohemia in the first half of the fourteenth century) calling on the faithful to utter, with varying intentions in mind, the Lord's Prayer and the Hail Mary. Was that call heard in the furthest corners of a vast parish? We have already discussed the very different levels of Christianisation in different villages on Polish territory. And in this context we can say that it appears that, in the centuries before the Reformation, the level of catechetical knowledge in the Polish countryside did not approach the level of pre-Hussite Bohemia. However, it also appears that, even in lands with the most thinly spread parishes, in the fifteenth century we do not see populations living beyond the Church's reach. To be sure, there were instances of religious ignorance and of disregard for the Church's commands, for example in the villages of Wielkopolska. Peasants called before a church court in Gniezno (1423) had apparently been working on Sunday transporting wood to market, and many of them did not know the text to the Apostles' Creed and did not want to learn it. ${ }^{28}$ That having been said, we do not know if, behind

27 Postilla Jana Rokycany, ed. F. Šimek, vol. 2 (Prague 1929), p. 804.

28 Acta capitulorum, vol. 2 (Krakow 1902), No. 197. 
this accusation, there lies an observation of parish reality, or if this accusation was but a reflection of local conflicts and antagonisms. In any case, regardless of the correct answer to that question, we must accept that, in Polish lands, there were areas that were underdeveloped in religious knowledge, where the Church demanded very little from the simple faithful.

There were also areas in the Teutonic states that were particularly neglected and marked by ignorance and illiteracy, most notably in the Samland diocese. It is doubtful whether monetary punishment for not knowing the Lord's Prayer or the Hail Mary, or barriers put up against complete religious simpletons taking the Eucharist, represented an effective antidote to this ignorance. In any case, the latter method was also used in the Diocese of Pomesania.

With the above reflections, it was not my intention to conclude that the Christian masses at the end of the Middle Ages were marked by a complete lack of religious knowledge. Such conclusion would be a gross exaggeration. However, I do want to point to neglect and ignorance in this regard, especially it would seem among a significant percentage of the population in Central and Eastern Europe, above all among its rural inhabitants. 


\section{Attitudes to the Sacred}

\section{The Duties of Good Christians}

By requiring the faithful to attend Sunday and holiday masses, the Church understood that such participation was an essential part of their religious education. And the fact is that, in the period under discussion here, the opportunities for laymen to participate in religious rituals organised by the parish and monastic clergy had never been greater. In fact, we might call the intensity of religious life in large cities in the Late Middle Ages extremely impressive. In the main parish churches of Prague and Wrocław, the great religious capital of Silesia, tens of thousands of masses were held, with various intentions, every year; the loco sacra, decked out with relics and endowed with indulgences, attracted the faithful from places near and far; numerous holidays created opportunities to perform liturgical and semi-liturgical rituals in front of the faithful. Inhabitants were attracted by new forms of devotion, both permanent and intermittent, which were brought to the lands of Central and Eastern Europe from the West, usually with a certain delay. For example, the morning advent mass, known as the rorate mass, came to the Kingdom of Poland through Bohemia and Silesia. In the fifteenth century, the earliest forms of the Lenten Stations of the Cross appeared in churches (certain references indicate that in the Teutonic state, this performance was taking place as early as the end of the fourteenth century). Later, we will discuss the eminently central-European culmination of the Eucharist ritual in the form of the Corpus Christi procession involving crowds of townsfolk. Processions of supplication (rogationes) took place in villages in the spring months, with the intention of promoting successful harvests. There was broad participation in what those in Poland called Dzień Zaduszny celebrations, closely associated with All Souls' Day, which took place in part at cemeteries. The above are examples of the diversity of ceremonial forms of religious life, all directed by the Church.

Efforts to enforce basic religious obligations on the faithful bore fruit in the fact that annual confession and the taking of communion at Easter was practically universal. It was known in the parish which individuals were neglecting these obligations, pressure from the Church in this regard was rather heavy, and scrutiny was harsh. Synodal legislation from the time does not indicate greater neglect, though the church scrupulously examined individual cases, especially if they were tied to Easter confession and communion taken by strangers. We should recall once again that the obligations under discussion 
here were to be fulfilled in an individual's own parish. Generally, an individual took communion not more than once a year; a practice that was not treated as a sign of a lack of religious fervour. We also find indications that some people took communion from three up to seven times a year, during the more significant church holidays, but such frequent appearances at the Sacrament of the Altar represented the exception and generally required agreement from the competent priest. The movement to renew Christianity through laymen taking communion on a daily basis (or at least often), which emerged in Prague in the second half of the fourteenth century, was an exceptional phenomenon in the Church. There will be a broader discussion of this issue in another place. Suffice it to point out here that, after mass access to participation in the Eucharist in the Hussite era was ended, and then as the fifteenth century came to a close, Catholics and Utraquists grew indifferent towards-and often blatantly neglected-this sacrament.

Use of the sacrament of confirmation was less widespread, participation in which was tied to the presence of bishops, who were not always eager to lead visitations to the parishes. Unfortunately, we know little about the application of extreme unction, which does not seem to have been treated as an essential viaticum for the world beyond, as opposed to confession and communion, which the church authorities tried to provide to the extremely ill, as conditions permitted. We often read about these sacraments in the records of miracles involving people prepared for death who regained their health. Marriages were most often concluded in churches, but, for example, in Poland, despite the bishops' order that the sacrament of marriage be carried out in facie ecclesiae, a nobleman could sometimes convince the priest to conduct the marriage ceremony at the nobleman's court.

We can see the centuries-old influence of the Church in the discipline of fasting, according to Church rules, and the least we can say is that we rarely hear of individuals breaking the obligation to fast. The number of days of fasting was the same in every diocese. For example, in the Diocese of Poznan the faithful fasted every year on the eves of fifteen holidays, and beyond that on Wednesdays, Fridays and Saturdays in four annual periods (the "Ember days") during Lent before Easter. We might add that, in the Polish Church, there was a tradition whereby fasting began 70 days before Easter and not, as in other Catholic countries, on Ash Wednesday. During this time, the staple food in noble and bourgeois families, which we know from sources, was herring and river fish. While in Poland it was generally optional for people to fast on normal Fridays, in Bohemia that day was treated rather rigorously as a day of fasting. Even dairy products were not consumed, despite the fact that the Church did 
not forbid them. Just as radicals in the Hussite movement rejected the Catholic fast, Bohemians in later times (but before the Reformation) began again to observe the fast strictly. The following opinion originates from precisely this period: "A Bohemian would rather steal horses than eat with butter on Friday." ${ }^{2}$ For this reason, the Utraquists, who treated mortification seriously, mocked Catholics for the fact that they did not consume meat on days of fasting and yet did not avoid filling themselves up with dairy and fruit. People who wanted to be more pious than average set for themselves additional fasting days under harsher conditions. The following case was not exceptional: an elderly lady from the Diocese of Kwidzyn in the Teutonic State, who was strict in her fasting for the Virgin Mary at least once a week, was satisfied by eating dry bread with water or beer.

That which more often provoked intervention by or criticism from the Church seems to have been the failure to observe holy days of rest, though cases of nonobservance were probably also sporadic in nature. The principle of how to properly spend a holy day was partially in conflict with the rhythm of public life. Gatherings of various kinds, including the noble sejmiki (regional assemblies), were held on holidays, which in turn energised trade, commerce, etc. But we must also note that craftsmen and merchants were obliged by relevant statutes to rest on the Sabbath, while guild authorities and local leaders were in charge of making sure those statues were respected. At the same time, the rhythm of field work encouraged farm workers to work on Sunday, especially in the summer. The Bohemian theologian Stephan of Roudnice (d. 1365) discussed this issue in his Quaestiunculae. In conclusion, he argued that farmers should be allowed to work on the Sabbath when harvesting grain and hay, as long as they respected the obligation to attend morning mass. ${ }^{30}$

The extent to which the faithful met these and other religious and church obligations is, of course, complicated, and it differed over time and space. However, generally speaking the Church expressed concerns more often about the way in which church duties were carried out than it did about whether the masses ignored them. We cannot help but recognise the essential role played by traditions passed from generation to generation, by prompts repeated again and again by priests over the course of parish instruction, and by scrutiny and evaluation carried out by clerics, particularly during confession.

29 Z. Winter, Život církevní v Čechách, vol. 2 (Prague 1896), p. 924.

30 The Quaestiunculae of Stephan of Roudnice, ed. R. Zeleny (Rome 1966), p. 33 (reprint from Appolinaris 38 [1965]). 
In the previous chapter, I discussed in broad terms the Church's expectations regarding the faithful and catechetical knowledge. It is also worth noting that, were we to attempt to reconstruct an image of Christian laymen and their stance towards Christianity in the period under discussion, it would consist, in principle, of their formal observance of the basic obligations, and thus participation in Sunday and holiday masses: fasting; going to Easter confession and taking communion; a knowledge of the three basic prayers; and making the appropriate offerings to the Church, according to local custom. Given the content of Church statutes, which only rarely penetrated the internal life of the laity, we can say, despite simplifying matters a tad, that one of the basic models of religious life for the simple faithful took shape around the above-mentioned practices and obligations, along with a few others. During the Hussite wars in Bohemia, one rural parish priest complained to the wealthy lord, about the Catholic faithful, that his parishioners at the time no longer celebrated church holidays, that they did not participate in processions, and that they ate meat on Fridays. We could cite more such statements that essentially represent, most often quite randomly, patterns and anti-patterns of Christian attitudes. They are worth consideration as one of the ways to perceive the common faithful in the Church. But collective religious life was significantly more complicated. In discussing this reality, which expressed itself above all in people's attitudes towards God and the saints, it is appropriate to begin with a person's most basic form of contact with the sacred, namely prayer.

\section{Prayer and Hymns in Church}

As was the case throughout Western Christianity, the faithful in Central and Eastern Europe who attended obligatory Sunday and holiday masses at the parish church did so by listening, essentially passively, beyond the expression of simple responses, without understanding the majority of the words spoken in the Latin liturgy. In addition, they performed the prescribed gestures that were appropriate for a given moment in the mass. As I mentioned in the previous chapter, in those places where the clergy had not neglected the orders of the church leadership, the assembled faithful uttered two or three of the basic prayers under the leadership of the priest. The content of these prayers was widely understood, as it was generally a fact that, in the countries of the region under discussion, they were spoken in the local language (although we should keep in mind the problems associated with the catechesis of Prussians in the Teutonic State). Occasionally, the complicated ethnic situation of an area was taken into consideration. As for the extent to which the faithful 
understood the liturgy, followers of the Bohemian Utraquist Church, who were able to preserve part of the earlier Hussite tradition, were privileged. The mass conducted in the national language was one of the most important aspects of this heritage. The Roman Church's approval was adjudicated at the Council of Basel in 1437.

In Central and Eastern Europe, the end of the Middle Ages witnessed the development of the hymn, performed by the Church faithful. Religious songs revealed the communal, collective nature of the petition, the thanksgiving, and other devotional content. As early as the fourteenth century, Bohemian churches reverberated with song, with the faithful appealing to Christ and-much as in other Catholic countries-to the Mother Mary and the saints. In 1408, and then later as the reformatory movement in Prague gained strength and the anticlerical mood expanded among a portion of the city's inhabitants, the Prague synod banned the singing of religious songs in the Czech language except for four old, traditional hymns. This move was supposed to prevent the propagation of hymn content which church officials found undesirable but, at the time, that had a powerful influence on the faithful. Later, on territory controlled by the Hussites, the use of Marian hymns about the saints ended after a longer time. They gave way to hymns that referred not to the saints (the worship of which radical Hussites rejected) but to God the Father and Christ. Nonetheless, the old hymns survived among Bohemian Catholics and, to some extent, in the Utraquist Church as well. In Poland, it was less common for the faithful to sing during mass, because the Church had long treated this form of prayer by laymen with suspicion. Some theologians even argued that the faithful could sing in church only during Easter. Change came in the second half of the fifteenth century, when Franciscan Observants (Bernardines) who had settled in the cities and were exhibiting great pastoral ambition, began to compose numerous hymns in the Polish language and propagate them in their churches. A new religious song had a powerful influence on the faithful's feelings: joy and hope (Christmas carols and Easter hymns), sadness and compassion (hymns of the passion). Those who recommended that Polish knights, as they prepared for battle, sing the old and majestic hymn Bogurodzica (Mother of God, which appealed to the Mother Mary for protection) were fully aware of the unifying and emotional character of some of these hymns. In Bohemia, the role of national religious hymn was played by the one of the oldest Czech songs, the Svatováclavský chorál (the Saint Wenceslaus Chorale), which appealed for protection from the patron saint of Bohemian lands.

We know very little about prayers recited individually by the common faithful during church mass. Occasionally, priests recommended them generally, 
arguing that it was a proper and pious kind of behaviour for people in a church. Members of the confraternities, which existed in all of the larger cities, had defined obligations regarding prayer. During common mass, they were to say the Lord's Prayer and the Hail Mary a defined number of times.

\section{Prayers of Petition, Prayers of Thanksgiving}

We know little about how common it was for individuals or families to pray at home. It seems that, in this context, what the Church required of laymen was not very rigorous. Preachers rarely raised this issue, and confessors were not interested in the matter of prayer in the home. Around the middle of the fifteen century, the Utraquist priest Jan of Rokycany, author of a vast collection of sermons for the people who was usually quick to criticise and cast blame, set a mild tone with the faithful on this subject by talking about how good it was to pray before going to sleep. He also recommended morning prayers based on recitation "from memory" of the Lord's Prayer and the Apostles' Creed.

Of greater importance was the recitation of prayer at the sound of church bells, usually twice over the course of the day, and as a rule in the evening, after sunset. In the post-revolutionary era, Jan of Rokycany, who we will recall expressed regret over the disappearance of piety in Bohemia, waxed nostalgic as he recalled his youth (before the Hussite movement) in his hometown when adults, upon hearing the evening church bell, first kneeled and called the children: "Children, where are you? Kneel, and give thanks to the merciful God." 31 $\mathrm{He}$ also remembered that, at the call of the church bell, people essentially fell to their knees and prayed on the spot: on the street, in squares, in the fields. In Poland in the fourteenth and fifteenth centuries, the diocesan synods recalled prayers being said on the Angelus. They recommended saying one Lord's Prayer with a particular intention in mind (most often it was peace, but sometimes it was prosperity for the king, princes, etc.) or the Hail Mary. The custom of the common prayer after the ringing of the evening church bell was practiced earlier in Silesia, where the Bishop of Wrocław, Nanker, called on the faithful, as early as the first half of the fourteenth century, to pray "for the good of the Church and for peace on earth." ${ }^{32}$ In later times, local authorities supervised the population's observance of this custom and harshly punished those who were negligent. At the end of the fifteen century, a certain craftsman was exiled from Wrocław for

31 Postilla Jana Rokycany, vol. 2, p. 804.

32 J. Sawicki, Concilia Poloniae, vol. 10 (Warsaw 1963), p. 357. 
having failed to stop his work after the church bell had rung and, in addition, for having complained about the nuisance caused by the obligatory prayer at that time of day.

So far I have spoken about prayers instilled in the faithful by the Church, both in terms of their content and their intentions. But there is no shortage of evidence confirming the notion that the faithful, including people from very simple backgrounds, took a lively interest in praying in their own way. Some of them, though probably only a few, wanted and were able to pray during the day, spontaneously and on an everyday basis, even if by only uttering a simple plea to God or the saints. Dorothea of Montau, a saintly mystic from a Prussian village who was completely possessed by religious sentiment, uttered many times during a day the name of Christ or made the plea: "God and My Lord Jesus Christ." 33 The average individual was familiar with similar pious utterances and requests for the guardianship of Providence. Prayer became more intense in life's dangerous moments, when serious illness threatened either the supplicant or the supplicant's children or spouse with death or disability. The same applied to difficult situations in everyday life. The records of miracles (miracula)-examples of supernatural grace, particularly those involving health, healing, and revival, and attributed to saints (or the dead with the odour of sanctity) recognised by the Church-contain the texts of prayers of petition recited in difficult moments. These records speak very often about a vow to make a pilgrimage to the grave of a holy figure or to a sanctuary dedicated to such a figure, which was often associated with additional obligations. We must remember, however, that what we are dealing with here are the texts of prayers appropriately edited by priests and monks recording testimony regarding acts of grace experienced by others. They no doubt altered the text according to theological correctness and subordinated its content to accepted conventions, including literary conventions. It is thus doubtful that the recorded text is the same as the original. We might well believe that the Hungarian captured by a Turk prayed to John of Capistrano for mediation in his liberation "from the hands of the enemies of all of Christianity,"34 but his prayer as a whole, known to us through the list of this saint's miracles, is a trifle too formulaic. Prayers speak to their own authenticity; those that are simple and

33 Die Akten des Kanonisationsprozesses Dorotheas von Montau von 1394 bis 1521, ed. R. Stachnik (Colonge-Vienna 1978), p. 270 (all further references and citations involving the worship of Dorothea of Montau are drawn from this work).

34 I want to express my heartfelt thanks to Dr. Gábor Klaniczay in Budapest for giving me access to copies of manuscript codices containing testimony on the miracles performed (in Ilok) by John of Capistrano. 
short, that are based on concrete facts, that refer to an unfortunate experience, and that contain a plea for assistance. A simple woman from Pomerania once turned reverently to Dorothea of Montau with the words: "I will not leave your grave until you return me my health. God knows how much I suffer." Or: "Oh blessed Dorothea! Help me, because I am suffering." ${ }^{35}$ About a century earlier, an impoverished resident of Krakow prayed for the return of his only horse capable of working: "Oh, blessed Jacek, you see my tears and my poverty, so give me back my horse, and I promise you that on every Wednesday, for the entire year, I will fast on bread and water." ${ }^{36}$ These prayers sound very genuine.

The supplicant occasionally "justified" the importance of returned health on the need to regain the ability to make a living. Katarzyna, a widow from the village of Liebenstadt in the Diocese of Warmia, who suffered from paralysis of the arms, prayed with these simple words: "Oh, most merciful Jesus, help me so that I will not have to beg. Because you know how badly I want to work, in order have something to live on." Małgorzata, who lived in the same village, prayed that her eyesight would be corrected, which was so weak that she was not able to help with the harvest. In the record of miracles performed by John of Capistrano, a famous priest who was buried in Ilok (then under Hungarian rule) and who died in 1456 with the reputation of a saint, we read of a farmer and a fisherman who, having experienced grace and thus regained their health, were able to return to work at their vocations. In all of these cases, it is easy to recognise the horizon of the prayers by people who wanted to be healthy in order to make a living, and for whom disability or infirmity meant poverty and social degradation.

Prayer, especially suppliant prayer, was accompanied by external manifestations of emotion. People cried while asking for a return to good health or for happiness, and they cried at a pilgrimage's destination; that is, at the graves of venerated personalities. They did not hide their tears, and their crying was a subject of discussion. In the descriptions of miracles, we also read of individuals with unrepentant hearts who, in their own words, had never cried before, but for whom prayer, in their chosen sanctuary, had released their tears. Residents of Kwidzyn who had shown no emotion even upon the deaths of their parents cried at the grave of the blessed Dorothea, where tears flowed "for what seemed like a half hour." Another person, in a Warmian town, who was unable to cry even when listening to a beautiful sermon on the Passion (during which all of the others

35 Die Akten des Kanonisationsprozesses Dorotheas von Montau, pp. 30-31.

36 Miracula S. Jacchonis, ed. L. Ćwikliński, in Monumenta Poloniae historica, vol. 4 (Lvov 1884), p. 890. 
attending the sermon wept bitter tears), had already condemned himself because of a hardened heart. But when he found himself in front of the grave of Dorothea of Montau in the Kwidzyn cathedral, he burst into tears "with such devotion that it was extraordinary." The virtue of crying, so valued by priests, is a gift of God, but it is, at the same time, an authentic component of mass piety. Individuals prayed with tears by themselves intentionally, but a collective representing various social estates prayed together, linked by a common intention. According to the Krakovian scholar and orator Stanisław of Skarbimierz, one unifying intention had as its focus the return to health of Queen Jadwiga, an enormously popular figure in Poland and the young wife of Władysław Jagiełło, during her serious illness in 1399: "I profess that we have prayed, that we have cried, and our voice has reached to heaven. We have prayed as we know now [...] and we shed tears, we held processions, and placed our votives." ${ }^{37}$ That having been said, other scholars of religious history have treated the above-discussed behaviours with scepticism, juxtaposing them with those patterns of piety whose nature and purpose involved the deepening of religious feeling. They have criticised those who: "believe that they are extremely pious because they shed tears easily." In this context, John of Capistrano is often cited, whose influence on the religiousness of the Utraquist Church was extremely significant, and who admonished those who, having entered a church, prayed with conspicuous gestures and cried loudly. However, he did not negate the value of devotional emotion: "when prayer is accompanied by tears, then it is very good and valued by God."

From the available sources we learn much more often about prayers of petition than we do prayers of thanksgiving, which results from, among other things, the particular nature of testimonial records about miracles, in which the internal reaction of the healed person was no longer the most important matter. However, occasionally we learn about the great excitement with which, and how ostentatiously, God and the saints were thanked for the return of health. We also read about signs of common human joy. Once, when the parents of a desperately sick child from a town near Buda were on their way to the grave of the princess and Dominican nun, Margaret, on an island between the banks of the Danube, they convinced themselves that their son had recovered his health, and they ended their pilgrimage with joyful song. ${ }^{38}$ In the descriptions of John of

37 Dzieje teologii katolickiej w Polsce, vol. 1, Średniowiecze, ed. M. Rechowicz (Lublin 1974), p. 326.

38 K. Bölle, Árpádházi Boldog Margit szenttéavatasi ügye és a legösibb latin Margit-Legenda (Budapest 1937), p. 38. 
Capistrano's miracles in Ilok, we see examples of communal prayers of thanksgiving delivered by huge crowds of faithful gathered there, accompanied by the triumphant ringing of bells, authenticating the performance of a miracle. Such an event was the manifestation of piety that was undoubtedly directed from above, by church officials, but which at the same time did not lack a certain spontaneity. We should not doubt that, in agreement with Church teaching, at least some Christians, in solitude and quietly, thanked God for the grace they had experienced.

\section{The Repetition of Prayers}

However, neither the most eloquent manifestation of feeling, nor the skill involved in addressing God and the saints with one's own words, nor expressive gestures made during prayer, determined the value and, above all, the effectiveness of prayer in the minds of the mass of Christians. Much like in Western Europe, the repetition of prayers, indeed frequent repetition of the most wellknown prayers-the Lord's Prayer and the Hail Mary-took on a dominant significance in the nature of piety at that time. This "arithmetic piety," which no doubt harkened back to old traditions of the hermit and the monk, was present in various social environments, among people representing different levels of knowledge and religious awareness.

Lay groups, who adopted specified religious obligations and, along with those, followed a certain model of life without severing ties with their family and professional lives (that is, members of the "third order" of Franciscans and religious confraternities functioning in and around urban churches), accepted the statutory obligation to recite the established number of prayers every day. However, in this regard they were giving way to certain individuals who manifested greater religious zeal. In the fourteenth century, a Pomeranian peasant, Agata, mother of Dorothea of Montau, is said to have repeated the Lord's Prayer a thousand times a day. She explained that number to the amazed bishops by stating that she prayed almost constantly during all of her daily activities, for example when cleaning the home and milking the cow. Dorothea surpassed her mother in religious zeal; she recited the Lord's Prayer and the Apostles' Creed every day from childhood. Dorothea spent the last years of her life walled off in her own cell in the Kwidzyn cathedral, and witnesses who provided testimony for the commission preparing the process of Dorothea's beatification (1404-1405) recalled that Dorothea was always ardent with her prayers. By way of contrast, other people-in the opinion of contemporaneous authors-most often prayed quickly and carelessly when reciting dozens, if not hundreds, of the 
most well-known prayers in the belief that they would thus build recognition in the eyes of God. Matthew of Krakow (d. 1410) juxtaposed the mechanical recitation of "thousands of psalms" with the essential values associated with the practice of Christian virtues. ${ }^{39}$ In Bohemia, "quantitative" piety, which at the beginning was harshly opposed by the Hussites for having no foundation in the Holy Scriptures, was later revived in the Utraquist Church. For this reason, John of Capistrano explained to his coreligionists that it would be better to say the Lord's Prayer once with full devotion and attention than to mutter it many times while thinking about something else entirely.

Generally speaking, despite criticism from some theologians, the faithful's tendency to repeat prayers was met with the understanding and support of the Church. At the same time, in all countries of Central and Eastern Europe throughout the fifteenth century, the use of the rosary became common, and although that usage came in forms that were different than would later be the case, it was always tied to the repetition of the very same prayers. Taking shape gradually, the rosary (known at first as paternoster, oratorium, zona oratoria) involved an initial prayer for everyone, because it consisted of text that every Christian was supposed to know: the Hail Mary and the Lord's Prayer. The Church recommended the rosary prayer when Europe was threatened by the Turks, attributing to it the powers of defence against danger. The rosary itself developed from the initiative of the mendicant orders, and in Poland the Franciscan Observant Władysław of Gielniów (d. 1505) discussed the simple formula for this prayer: "Say the Zdrowaś badź, Maryjo three times fifty, and with each group of ten comes one Lord's Prayer." ${ }^{40}$ The rosary tied the piety of elites to that of the masses, educated people with simple folk. Both the clerici and the laici prayed the rosary, as did rulers in the Jagiellonian dynasty and members of the Franciscan "third orders." A particular miniature depicting a pilgrim with a large rosary walking to the grave of Saint Hedwig of Silesia attests to the extent to which people in Silesia in the middle of the fifteenth century were familiar with the rosary. Diocesan authorities in Wrockaw supported the spread of the rosary prayer, although they adjusted the way in which it was recited. The Bishop of Wrocław, Rudolf von Rüdesheim, who fought against haste and thoughtlessness

39 Mateusz z Krakow, Opuscula theologica dotyczace spowiedzi i komunii, in Materiaty do historii teologii średniowiecznej w Polsce, vol. 1, eds. W. Seńko, A. L. Szafrański (Warsaw 1974), p. 408

40 Chrestomatia staropolska. Teksty do roku 1543, eds. W. Wydra, W. R. Rzepka (Warsaw 1984), p. 251. 
in prayer, exhorted the faithful to let the rosary fall from their lips as "a prayer to, and not a reproach of, the Mother of God." 41

Faith in the certain-as it were, guaranteed-effectiveness of prayer found its reflection in the tendency to repeat prayers. People attributed decisive significance to the recitation of a certain number of prayers that were reliable for certain intentions. Given this faith in the automatic effect of such prayers, the attitude emerged that it represented a kind of contract with God, who was supposed to honour this contract because the person offering the prayer had contributed to the agreement. The role of the petitional attitude was thus disappearing, and the significance of religious feeling was reduced; in effect, prayer was beginning to resemble incantation, and its effectiveness was decided by the ritual recitation of the holy words.

\section{The Prayerful Gesture}

Prayer was accompanied by gestures. While some of these gestures belonged to a durable and venerable liturgical tradition guarded by the Church, others were shaped by laymen and subject to their inventiveness. Most of them were common gestures, which included making the sign of the cross and folding hands, and the increasingly common kneeling and bowing of the head, all of which were practiced by both clerics and laymen, rich and poor, educated and uneducated. Kneeling accompanied by prayer and the adoration of God and the saints, a combination that occurred earlier in Church history, was established as correct religious behaviour for laymen only in the Late Middle Ages. Without applying coercion, the Church encouraged the faithful to worship God on their knees and subsequently promised them an indulgence for the act. At the end of the fourteenth century, the Prague synods envisioned forty days of indulgence for piously kneeling in church when the celebrant uttered out loud the name of Jesus Christ or the Blessed Virgin Mary. Those attending a mass were encouraged in a similar fashion to kneel during the Elevation (earlier, the faithful had experienced this sublime moment while standing).

In the records of miracles experienced through the mediation of the saints, it is prayers of petition that were most often accompanied by gestures. In her valuable study of pilgrimages to the graves of local Cracovian saints in the fifteenth

41 K. Dola, "Problemy kościelno-duszpasterskie w diecezji wrocławskiej w XV w., Sobótka, No. 4 (1986), p. 532. 
century, Aleksandra Witkowska concisely characterised the external behaviour of people petitioning for supernatural grace:

Very simple and yet extremely eloquent forms of prayer were still practiced, as were prayers said with arms crossed or hands folded, short prayers, and long vigils intended to draw out the miracle, during which the supplicant would stand, kneel, fall to the ground, and sometimes lies down like the cross. Prayers spoken out loud were often accompanied by tears, lament, and cries that spontaneously expressed a reaction invoked by deep emotional tension. ${ }^{42}$

We see essentially the same behaviour everywhere in cases in which unfortunate and distraught people turn to God and the saints for assistance. We thus often read that people offering an oath would do so on their knees, which passed for a manifestation of exemplary piety. No doubt it was not only the Hungarian followers of John of Capistrano who raised their folded hands high, and turned their gaze towards heaven. But a kind of behaviour that was relatively rare was exhibited by women in Pomerania who, having arrived at the grave of Dorothea of Montau, stood against the church wall with outspread arms and prayed while holding this position. Several decades earlier in distant France, in another spiritual and social environment, the father of the young Jean Gerson, who was to become a great theologian, adopted a similar gesture, saying: "Look, my son. Our Saviour was crucified like this." ${ }^{33}$ Impulsive, ostentatious and even violent gestures were not uncommon. Some believers fell to the ground, or to the church floor, in a gesture of humility, or they bowed deeply before the symbols of the sacred and in places where the sacred was present. These movements and positions were an expression of that kind of piety in which the gesture often meant more than the word; it expressed clearly defined content, and it could be seen and recognised by God and others nearby. After all, people attending church observed what others were doing, and in the process they recalled the signs of exemplary and exceptional piety, along with the kind of behaviour that clearly diverged from the common image of what it meant to be pious.

\section{To See and Be Close}

A person attempting to establish contact with the sacred through prayer, by turning to God with his or her requests through the use of words and gestures,

42 A. Witkowska, Kulty pątnicze piętnastowiecznego Krakowa. Z badań miejską kultura religijna (Lublin 1984), p. 200.

43 For more on this subject, see F. Rapp, L'Église et la vie religieuse en Occident à la fin du Moyen Age (Paris 1971), $146 \mathrm{ff}$. 
most often did so while in the presence of church symbols and signs of the Christian religion. In the two final centuries of the Middle Ages, throughout Europe including Central and Eastern Europe, religious symbols appeared increasingly often beyond churches, chapels, and the grounds and cemeteries that belonged to them. They included crosses put up where roads intersected, which served as signs of Christianity intended for travellers. Wayside shrines were also placed along cemetery walls. From the end of the fifteenth century, such shrines in Silesia were equipped with reliefs of Jesus on the Cross, Saint Barbara, Saint Anne, and Saint Hedwig, patrons of Silesia.

Over time, private devotional objects-household altars, reliquaries, images of the saints-began to proliferate not only at royal courts and in the homes of the great magnates, but also in noble and bourgeois environments. If we are to believe an old Bohemian verse from the end of the fourteenth century, paper illustrations of holy characters, distributed throughout the countryside, were extremely popular among pious peasant women.

Instruction on the real presence of Christ in the Eucharist, given by the Church to the faithful and challenged only by followers of heretical movements, enabled a clear view not only of the symbols of worship, but also the very objects of that instruction, namely the body of Christ concealed in the host. The kind of adoration encouraged by the clergy found natural support in the human propensity to comprehend the deity, present on earth, through sight, by which the act of looking upon the host became a spiritual need for the followers of Christianity, and an essential and rather widely cultivated devotional practice. This need on the part of the faithful, evidence for which we find in thirteenth-century sources, grew in strength along with the development of the cult of the Eucharist, and it continued until the last days of the pre-Reformation era. It manifested itself in efforts to gaze, often and for as long as possible, at the host held high by the priest during mass. Some individuals paid tribute in this way to the body of Christ as depicted in the form of the Eucharist, and the ritual of the Elevation was connected in those days with a deep religious experience. Others associated this type of worship with a deep conviction that, having caught a glimpse of the host, they would be protected on that day against any evil. The faithful reacted to being deprived of the possibility to view the host as they would to a painful experience. In the 1330s, in connection with an interdict imposed by the Church on the city of Wrocław, Bishop Nanker, who wanted to maintain discipline, ordered that church windows be guarded so that the faithful would not climb up them to get a peek at the host during mass held in empty churches. Evidence referring to Bohemia and Poland confirms that laymen applied pressure on priests to repeat the ritual of the Elevation several times, which provoked opposition from church 
authorities and criticism from theologians. Alongside faith in the hidden, magical powers of the host, the mere opportunity to look at the host was regarded as a manifestation of correct and proper piety. In one church in southern Bohemia in the first half of the fourteenth century, when the faithful noticed someone failing to watch as the monstrance was raised and thus exhibiting behaviour outside the norm, questions were raised about whether that person was a heretic-a Waldensian. ${ }^{44}$ Many people regarded the ritual of the Elevation as the most important and central part of the mass. Some residents of large cities in which there were several churches would visit them on Sundays and holidays one after the other in an attempt to witness the Elevation in each of them.

Theologians condemned belief in the magical powers of the host particularly when believers openly ignored participation in the broader mass. Scholars reproached laymen for the reprehensible practice of attending church only for the Elevation. The Bohemian Johlín of Vodňan and the Pole Mikołaj of Błonia witnessed, in their respective countries, church-goers leaving mass immediately after the Elevation. ${ }^{45}$ The Hungarian Franciscan Observant Osvoldus de Laska spoke bluntly when he noted that some people ran out of the Church so fast, it was as if they had seen the devil. We do not know in what period the Utraquist Church endured similar beliefs and attitudes, but lazy parishioners, with which Jan of Rokycany was familiar, could apparently be heard saying: "They're already ringing the bell? There's still enough time to get to the church, it's a long while until the Elevation." ${ }^{46}$

The desire to see with one's own eyes that which was unearthly and supernatural emerged in Central and Eastern Europe most clearly from the end of the fourteenth and beginning of the fifteenth centuries. It was at this time that the worship of the miraculous host developed, which involved hosts being saved from devastation and fire and-generally a little later in time-from attempts at profanation. The faithful from Poland, Bohemia, Silesia, the Teutonic state, Hungary and Transylvania, joined by other pilgrims from German lands both near and far, flocked to the Brandenburg village of Wilsnack, where in 1384 three consecrated hosts, which survived a fire that had burned down the church, were found with blood on them, and all of these pilgrims came wanting to get

44 Quellen zur böhmischen Inquisition im 14. Jahrhundert, ed. A. Patschovsky (Weimar 1979), p. 181.

45 R. Řičan, Johlín z Vodňan, Křižovník kláštera zderazského (Prague 1930), p. 72; M. T. Zahajkiewicz, Teoria duszpasterstwa in Dzieje teologii katolickiej w Polsce, vol. 1, p. 245.

46 Postilla Jana Rokycany, vol. 2, p. 236. 
a glimpse of the blood of Christ. Debates among theologians about the authenticity of this phenomenon, along with concerns raised by a special commission and local church authorities, did not put an end to this form of worship, which involved the spontaneous support of common people, but which also resonated among the highest social elites (its reputation was fed by, among others, the Polish queen Jadwiga and no doubt by others in her entourage). Similar events began to take place in other territories, and they did so not without the participation of diocesan and monastic priests. In Poland, we see the early signs of the motif of the miraculously rescued host emanating from the pilgrimage milieu of the fifteenth and sixteenth centuries at the Carmelite Corpus Christi Church in Poznań. In the Teutonic State, the faithful paid tribute to hosts rescued in Malbork and Elblagg. Disputes over the right to maintain these hosts in parish churches is testimony to fears that these rescued particles of the sacred, which had descended to the people, would be lost, and the fact is that-and this was, of course, not without significance-their presence brought fame to local churches. If, however, we are to believe the above-cited Bohemian preacher, Johlín of Vodňan, some of the faithful wanted not only to look at a host that had traces of the Lord's blood, but they also wanted to possess it, to preserve it, and to show it to others. Investigating these practices, Johlín did not treat them as sacrilege, because he did not believe that wafers kept by people were consecrated hosts. For us, his statement is interesting to the extent that it confirms a need that characterised religiousness in the Late Middle Ages, namely the need to gaze upon things that were supernatural and, whenever possible, to be close to them.

People also wanted to be near those material signs of supernatural power to which they had greater access. The worship of relics, which had existed in Christianity for centuries, spread tremendously in the Late Middle Ages. Initiatives taken by Church leaders and lay authorities, along with the Church liturgy itself, accommodated the tendency among laymen to come into close contact with holy vestiges. Among the celebrated rituals involving the presentation of relics for public viewing, the most prominent were those introduced by Charles IV in 1349. According to this ruler's wishes, thousands of inhabitants of the capital city and crowds of pilgrims were able to view the holy relics associated with the imperial coronation, displayed in the New City, which included the lance that had pierced the Saviour's side, along with a piece of wood and a nail from the cross on which he had been crucified. The ceremonial display of relics at Saint Vitus Cathedral and several other prominent churches naturally enjoyed somewhat less success. Every few years in the Teutonic State, a great number of pilgrims would descend on Malbork castle to view relics assembled in 
Saint Mary's Chapel that had been collected by the Order, the most valued relic being what remained of the wooden Holy Cross. The worship of the Holy Cross to which these relics were tied had, of course, a reach that was quite broad. On Polish lands, the monastery of the Holy Cross, a Benedictine sanctuary located in the Góry Świętokrzyskie (in northern Małopolska) became an important pilgrimage centre. As many as five churches in Wrocław prided themselves on their possession of relics such as those described above.

However, let us return momentarily to the broader topic of the practice of displaying holy relics for public viewing. No doubt there were various reasons behind the success of these events. An essential factor in their success involved the possibility that participants might receive one of the many generous indulgences offered by the Church, which the faithful eagerly sought. Having said that, we cannot forget the fact that the faithful were able to take advantage of the opportunity, quite simply, to come into contact with what was commonly regarded as holy.

Rulers and magnates, noblemen and burghers, all displayed a desire to possess their own private relics. Even simple folk expressed such desires. The possibilities here were broad, and they involved the quantity and quality of the relics a person possessed. Certainly no one could equal Charles IV, with his true fervour in collecting holy remains originating from various corners of the Christian world. He put great effort into finding new relics for himself, and he joyfully accepted them as gifts; indeed, it was one of several important manifestations of his very peculiar piety. In Poland in the fourteenth century, Vice-Chancellor of the Kingdom Grzegorz of Lubrańca was able to boast of a huge collection. Among the obvious examples of relics of Polish patron-saints-Wojciech, Stanisław, Florian, Jadwiga (the wife of King Władisław Jagiełło) - there was no shortage of relics of other individuals whom we might well regard as extraordinary: ten thousand knights and eleven thousand virgins. In Silesia, the princes of Oleśnica were collectors of relics. Beyond the magnates, the demand for relics (of a lower rank, naturally) was so large that people with access to them often abused that privilege. A priest once stood before a church court in Włocławek accused of removing "the relics and bones of saints from his church." ${ }^{47}$ The poorest among the faithful tried to take things to which they had relatively easy access, even if it was only dust from the grave of a character famous for his miracles. Some people constantly carried relics under their clothing, which raised the suspicions of theologians, who saw indications in this behaviour, not without reason, that

47 Acta capitulorum, vol. 3, part 1, No. 489. 
relics were being treated as something magical, as amulets defending people against misfortune.

\section{Penetration by the Secular}

Alongside many of the phenomena discussed above revolving around the religious life of the faithful, we are also able to observe the penetration of secular attitudes and secular behaviour into the sphere of religious ritual and worship, which came as the result of several factors, including: greater participation by the people in religious rituals relative to previous years; greater church attendance; and the fact that, generally, what had largely been unusual and mysterious had now become, in a sense, ordinary. A kind of familiarisation with religious ritual led to the mutual violation of once established spaces occupied by, on the one hand, matters tied to the sacral sphere and, on the other hand, matters tied to the temporal, secular sphere. From among the many manifestations of this phenomenon, let us direct our attention to the behaviour of the faithful in churches. Evidence from the sources on this subject is very telling and valuable, and although it is often tendentious and marked by excessive generalisations, it most importantly opens a window to clerical criticism of laymen and their actions.

I have not yet discussed the fact that the church, particularly the parish church, where residents gathered for Sunday masses, served-quite apart from the church's sacral character-as a natural meeting place for laymen, one that was both social and public. The secular role of churches grew over the course of the fourteenth century. As mentioned above, the sejmiki (regional noble assemblies) in Poland, which were often turbulent and not without their excesses, met in churches. In Bohemia, local parliaments met in churches run by the mendicant orders, and representative delegations of large cities gathered in parish churches. But even the behaviour of those participating in religious rituals diverged from the exemplary. Discussions during mass, stories arousing laughter, and persistent conversation conducted in whispers, were not exceptional. The sacral space was infiltrated by matters of everyday life, public life, entertainment, holiday, and rest. The subjects of discussion, as described by an unknown Polish priest in the fifteenth century, probably involved noblemen and burghers, because there was talk of dogs and rabbits; of the king, war and various other events; of grain, fields, and markets; of the horse trade; and, finally, of where a person might go to get a good drink. Bohemian priests in the fourteenth and fifteenth centuries saved their harshest criticism for young people and their behaviour in churches. Much to the dismay of the Prague preacher Konrad von Waldhausen, boys once harassed the

girls during his sermon, and even threw stones at them. Girls would attempt to 
attract the interest of eligible young men attending mass with their stylish and not-always-modest clothing and suggestive glances. Young people flirted with each other, and old people dozed. Many decades later, in the Utraquist community, some of the faithful apparently went to church mainly in order to impress others with how generous they were in giving alms, or to show off their beautiful singing. In the opinion of Osvaldo de Lasko, who was very familiar with the layman's vices, there was in Hungary no shortage of people who arrived late for mass, and then during the mass allowed their eyes to wander. The course of the sacral ritual no doubt altered by the behaviours and attitudes learned in secular life, which softened at certain defined moments of the mass, when respect for the Eucharist, during the Elevation, induced those attending the service to be quiet. It was different during the Offering, when the faithful's movement towards the altar encouraged chaos, particularly when rural parishioners were offering gifts of nature. In later times, Mikołai Rej, a Polish writer associated with trends in the reformation, made fun of this custom, saying: "hens are clucking, pigs are oinking, and eggs are being counted at the altar." ${ }^{38}$

Sermons did not always hold the congregation's attention. Despite the efforts of the church authorities and authors of religious tracts emphasising the significance of predication, the faithful often treated sermons as a kind of interlude in the service, a time to relax, a time in which they could engage in conversation. From the fifteenth century, Polish and Bohemian authors of sermons tied the faithful's attitudes in this regard to social status. A Polish priest once explained that poor and shabbily-dressed churchgoers, despite the chilly temperatures in the church, listened carefully to the sermon, but rich churchgoers, dressed in marten or fox furs, could hardly bear to sit in the church for a mere an hour. Based on the same principle, the Bohemian Jan of Rokycany identified the different ways in which the faithful participated in divine worship:

After all, it is easy to see: those people, poor yokels and old grandmas, trudge off to church before dawn and they sit there for the entire mass [...], but the rich people lay around late in their homes and then drag themselves off to church, arriving there at the last moment. ${ }^{49}$

48 Mikołai Rej, Różne przypadki świata tego. Wybór utworów satyrycznych, edited by A. Jelicz, intro. K. Budzyk (Warsaw 1953), p. 26.

49 Postilla Jana Rokycany, ed. F. Šimek, vol. 1 (Prague 1929), p. 151. For a similar statement by a Polish priest, see A. Brückner, Kazania średniowieczne, part 3 (Krakow 1896), p. 21. 
Those rich people-that same author noticed in another place-were not interested in the words of the sermon; they listened to the most severe charges with indifference; and "some of them doze off instead of listening to the word of God and do not even regard that as a sin." According to earlier writings of Johlín of Vodňan, other people suspected that every critical opinion expressed by the priest was aimed directly at them, and they did not hide their anger. The stereotypical divide between pious and patient poor folk and proud rich people who neglected the welfare of their own souls was entirely detached from reality. Representatives of the nobility and wealthy bourgeoisie, especially those who had a higher level of education, received the content of sermons more critically than simple folk who arrived at the church unprepared and were less daring during mass. We read of cases in Poland in the fifteenth century in which large groups of faithful left the church in the middle of a sermon that had met with their dissatisfaction. Certain laici litterati, who no doubt belonged to the nobility or the upper bourgeoisie, would leave churches talking about the preacher with contempt: "Why do we have to listen to this comedian (istum ribaldum), given that we know the Holy Scriptures better than he does?" ${ }^{0}$ Having said that, in the two centuries before the Reformation, relations between the laity and clergy, including at the parish level, were notably complicated. While certain cases were marked by sharp antagonism, there were also signs of harmonious coexistence.

\section{Blasphemers, Sceptics and Non-Believers}

Words used to signify the three persons of God mingled with colloquial speech and sometimes became a kind of incantational formula which, once it became ordinary, lost its sacral character. Such words were used in various contexts, for example to buttress the content of one's requests. The cloth vendor thus called upon God to strengthen the buyer in the latter's belief that the transaction would be beneficial to him. The shoemaker who wanted to convince an unbelieving client of his honesty gave assurances by saying: "God is our witness." In Bohemia, the word Bóhdej (which essentially means "Let God provide") moved into colloquial speech and was used with content that was purely secular. For this reason, Jan of Rokycany complained to his faithful: "The name of God has become so commonplace for the people that, when they want to drive away a dog, cat, or pig, they say: Bóhdej tě vlci" ${ }^{51}$, which literally means: "Let God have the wolves

50 M. T. Zahajkiewicz, “Teologia mszy świętej i udział wiernych w nauce polskiej okresu przedtrydenckiego," Acta Mediavalia 1 (1973), p. 90.

51 Postilla Jana Rokycany, vol. 1, p. 479. 
devour you". In popular oaths and incantations, the sacred appeared in an ordinary form, devoid of religious majesty and power. People were in fact not even aware of this reality, and only pastoral theologians perceived the offences committed by laymen, and they occasionally threatened to attach the labels of blasphemy and sacrilege to the culprits.

Statements undermining the religious worship of God, the Mother Mary, and officially worshipped saints were actually quite rare, a fact that also applies to Bohemia before the radical Hussites temporarily overthrew the value system that had long been dominant. Without the context of the Hussite wars, it is difficult to imagine the scene that an appalled priest described to Oldřich z Rožmberk in which people who, having brought a loaf of bread to church, reached out with the bread to the figure of Jesus and said: "If you are God, then eat this bread." ${ }^{2}$ Of course, these individuals were neither unruly blasphemers nor sporadic nonbelievers demonstrating their attitudes publicly, but rather Hussites, Taborites who-following in the footsteps of many earlier heretics-categorically rejected and condemned figures, sculptures, and images representing the persons of God.

Instances of the use of words that the clergy and pious witnesses viewed as blasphemous were occasionally dealt with in Poland by church courts. The transgressions under discussion here were often committed in the framework of particular circumstances: a quarrel, drunkenness, etc. Occasionally, they reflected conflicts between laymen and clergyman at the parish level. At the same time, accusations of blasphemy provide evidence of how sensitised Christian society was to statements that offended the already deeply rooted reverence for the persons of God and the saints. Individuals who offended Christian reverence for the Mother Mary were treated particularly harshly. Cases of blasphemy were thus relatively rare in the societies of Central and Eastern Europe in the Late Middle Ages. In addition to the fear of consequences of a purely religious character (for having committed a deadly sin), there was fear of a severe temporal punishment and public reproach. In the fourteenth century, an Inquisition court in Bohemia punished a blasphemer from the city of Cáslav. The repentant wrongdoer was forced to stand in front of the doors of the local parish church every Sunday for seven weeks waiting for the faithful to exit the church. His greatest humiliation was reserved for the last Sunday: stripped to the waist and with a rope around his neck, the sinner held a cane in his hands with which everyone had a chance to whip him in any way they pleased..$^{53}$

52 Z. Winter, op. cit., vol. 2, pp. 916-917.

53 A. Patschovsky, Die Anfänge einer ständigen Inquisition in Böhmen (Berlin-New York 1975), p. 132. 
Occasionally, individuals were labelled a blasphemer if they refused to worship a saint or the dead with the odour of sanctity whose future canonisation was a matter of concern for local church communities. It was blasphemy when a certain village woman from near Malbork, talking about Dorothea of Montau and her miracles, said that all of that had been made up by the local canonry for money. But this woman was neither a heretic nor a mouthpiece for any particular criticism on the matter of faith. Other cases, widely noted in the protocols of miracles and which involved individuals experiencing doubt in the power of saintly characters worshiped by the people and the local clergy (including those that had not yet been entered on the list of Roman Catholic saints), did not necessarily indicate that those individuals were experiencing religious scepticism. It could even be argued that these cases were an expression of reliance on the officially-stated Church position. Once, a certain burgher from Krakow refused to recognise the intercession of Stanisław Kazimierczyk, who was worshiped in that city from the end of the fifteenth century, with the following words: "After all, he has not been canonised. How can he be a saint?" With the assistance of individuals editing testimonies on miracles, the promoters of accepted cults depicted doubters tendentiously as habitual doubters and sinners, who would usually be converted under the influence of the "miracle of punishment" (that is, temporary revocation of experienced grace), but who would occasionally have to bear the burden of persistent punishment for their unbelief. We might note, by the way, that in statements made by doubters and recorded for posterity, in whose imagination a "real" saint recognised by the Church appeared as an extraordinary character, one who was distant from everyday reality, we only rarely find a tone that represents a rational approach to matters involving life and death. An exponent of such an attitude appears to have been a certain Hungarian, whose son had died, and who, before Saint Kinga brought the boy back to life again, said "whoever is dead, remains dead" (Qui mortuus est, mortuus est)..$^{54}$

Homiletic and moralistic literature, including chronicles, from the Late Middle Ages stubbornly repeats the motif that the people disregarded the Church's instruction concerning eternal life, that they lacked a fear of punishment, and that they lacked joyful hope in salvation. In the middle of the fifteenth century, the chronicler Jan Długosz, reflecting on Polish Christianity, noticed bitterly:

54 Miracula sanctae Kyngae, ed. W. Kętrzyński, in Monumenta Poloniae historica, vol. 4 (Lvov 1884), p. 735. 
Ridiculing God's laws and dictates, we do not fear the prophetic threats of the Holy Scriptures and we do not take to heart God's commandments; we do not want to think about the future life and salvation, as if we will live forever.

Much earlier, the Praguer preacher Konrad von Waldhausen, author of many popular collections of Sunday sermons, rebuked his listeners in a similar tone: "When a preacher talks to you about heavenly joy, you pay no heed, and when you hear about the torments of hell, they seem to you to be fairy tales." Johlín of Vodňan, an observer and critic of the religious life of laymen as the pre-Hussite age was coming to an end, also thought that, even though many of them knew much about the true faith, they in fact had faith in nothing. But what Konrad von Waldhausen had to say about those who demonstrated their piety only out of fear of hell was something quite different: "If there were no hell, they would not say even a single Lord's Prayer." ${ }^{55}$ We could cite many more such opinions, admonitions and exhortations that are mutually reinforcing or explicitly contradictory, but I do not happen to believe that they would be very useful here; after all, they served immediate and temporary moralistic ends and were a rhetorical instrument dependent on the content of the particular argument being made.

We must judge somewhat differently the evidence put forward by authors who deplored religious indifference, discouragement among the faithful, and outright unbelief (variously articulated) in Bohemia in the Jagiellonian age; that is, in a country where the old Church was decrepit and the new and reformed Church was not yet established. Jan of Rokycany, who was pained by the people's exhausted piety, cited the words of a person in a quandary over religion, a person from his own generation: "I have been going to church for fifty years and only God knows if it has not been futile." But this example of discouragement towards religious practices and pessimistic reflection on a human's sad fate still does not seem to be a manifestation of unbelief. Nor is it the view expressed by some people who would apparently prefer, "that God not exist at all, so he would not punish us, and we would be our own rulers."

We read the words of scholarly authors who were terrified by the prospect that the Christian religion would disappear altogether. They heard individuals who doubted the dogmas of the faith, who despised divine worship, who believed that the human soul died with the body, who did not believe at all in life after death. The Bohemian humanist Bohuslav Hasištejnský (d. 1510) complained

55 F. Šimek: Staročeské zpracování Postily studentů svaté university pražské Konráda Waldhausera (Prague 1947), pp. 69, 116. 
about these unbelievers in an ode to Saint Wenceslaus: "They have no faith at all in heaven. For them, God is but a made-up fairy tale, and among us even a little boy is no longer afraid of hell." 56

Such attitudes and opinions-we do not know how numerous they actually were, although they certainly did not appear on a mass scale-had little in common with modern, rational atheism. The Czech historian Josef Macek, author of a brilliant study on faith and religion in Jagiellonian times, was most likely justified in writing about manifestations of what he called spontaneous unbelief and superficial unbelief, regardless of whether that was the result of religious ignorance, life experience, or personal observation. Macek emphasised the universal character of these attitudes, which were more or less common in many countries before the Reformation. In Poland at the beginning of the sixteenth century, a church court took up the case of Michał, a tailor from Płock in Mazovia, who had apparently come out in opposition to the clergy and the Holy See, and who in addition argued against the existence of heaven, hell, and life after death in general..$^{57}$ The court ascribed Michal's statements to his belonging to a cult, though it seems that he was in fact little more than a wisecracking doubting Thomas. However, Catholic authors in Bohemia during the Jagiellonian era associated such attitudes with the inhabitants of their own country, which, for reasons tied to the Hussites, was broken up into denominational groups, disoriented, and lacking in authority. They argued that the introduction of communion in two forms brought in its wake the separation of Bohemia from the unity of the Roman Catholic Church, rampant religious aberrations, and an atmosphere that encouraged the influx of all kinds of enemies of the faith. The Bohemian writer and traveller Bohuslav Hasištejnský complained at the end of the fifteenth century: "Because in Bohemia there is also the custom that one believes what one wants and as one wants." ${ }^{8}$ Other authors detected the legacy of radical Hussitism in what they viewed as the denial of the truths of the faith, in mockery of the holy rites, in outrages against God and the saints; they all tended, in their bitterness and nostalgia, to associate the beginning of the evil that ruled the world around them with the Hussite movement. Occasionally, they did not ponder too deeply the content and logic of the phenomena they were describing, and sometimes they linked stances and attitudes that were, in fact, completely distinct.

56 J. Macek, "Víra a náboženství v jagellonském věku," Studia Comeniana et Historica 19 (1989): p. 10.

57 Acta capitulorum, vol. 3, part 1, No. 244.

58 J. Macek, op. cit., p. 23. 
However, they were not mistaken about the fact that, especially in its radical form, Hussitism fundamentally taught people to openly doubt that which had been indisputable, to deny the truths of the faith, and to neglect the teachings of catechists and moralists. Exhausted religious enthusiasm tied to the Hussite revolution and the disappearance of discipline, which created a situation that disallowed the expression of views other than those accepted by the new faith, created the conditions for the rise of the kinds of beliefs and convictions I have discussed above. However, this ideational chaos, over which Catholics lamented, and which the Utraquists also experienced, was not the decisive phenomenon by which the image of Bohemian Christianity at the turn of the sixteenth century was created. Rather, it was one element of an extremely complex religious situation in the country, which was marked by manifestations of the disappearance of religious life and indifference towards (and ignorance of) matters of faith, but also by increased and zealous piety, both among Catholics and Utraquists. 



\section{Directions and Aspects of Piety}

The internal attitudes, feelings, and practices of the Christian masses, despite signs of independence from (and occasionally resistance against) Church pressures, did not diverge far from the main currents of religiousness as directed by the Church authorities. Generally speaking, these currents were prevalent throughout Western Christianity, though in the region under discussion here (Central and Eastern Europe), we could find local differences and peculiarities, and particular strains of thought and action. Intellectual and religious elites, along with members of the parish and monastic clergy who did not close themselves off entirely within a sphere of their own issues, also directed parts of their programs and ideas towards the faithful at large. In such programs, we can find reactions to matters related to mass piety that ranged from support for it to opposition to its unwanted manifestations, on the part of theologians, priests, and advocates of the renewal of religious life. The faithful, as well, did not always and everywhere accept the path laid out for them by advocates of new devotional directions. It would thus be appropriate for me to occasionally depart from my main path of argument; that is, from the issue of mass religious phenomena, to devote some space to programs and demands formulated by scholarly individuals and members of elite spiritual groups, whose ultimate goal was to expand the community of the faithful.

\section{The Path to Christ}

In the second half of the fourteenth century, programs began to emerge from various religious groups (theologians in Prague and, somewhat later, scholars in Krakow as well as members of certain monastic circles, including Canons Regular under the Rule of Saint Augustine in Bohemia and Silesia); programs that were variously conceived but focused on a remarkably Christ-cantered piety, and which were guided by original Christian sources: the Gospel and the sacraments. They rejected the formalism and ritualism of worship; they downplayed the importance of traditional ascetic practices and internal manifestations of piety. When addressing the laity, they proposed a kind of piety that was accessible to everyone, based on individual prayer full of emotion. They highlighted the significance of the practical side of Christian life: the realisation of virtue and the battle against sin. A particular place in piety thus conceived was occupied by the worship of Christ the man, His sacrifice and agony, and the main focus became the imitation of the Saviour in human life. 
Leaders in the establishment of new paths for the internal life, which were inseparably tied to ideas to revive the Church and Christianity, were the Bohemian authors of religious works and preachers Jan Milíc of Kroměříze and Matthew of Janow (d. 1394), along with their colleagues and continuators. We must also note, separately, the secular thinker and moralist Tomáš Štítný of Štítného (d. before 1409), the author of uplifting treatises on religion in the Czech language. Among the proponents of the new piety (or "modern devotion") in Central and Eastern Europe, certain distinguished bishops in Prague stand out, especially Arnošt of Pardubice, protector of reformist individuals and groups, and the initiator of measures designed to repair clerical life. Ideas expressed in Prague reverberated in places like Krakow, where theologians at the restored University of Krakow reformulated them in a similar spirit. Usually mentioned in this context are such scholars as Matthew of Krakow and Stanisław of Skarbimierz (d. 1431), both of whom were educated at Charles University in Prague, along with younger men like Jacobus de Paradiso (d. 1464). Carriers of the new piety on Hungarian territory were Pauline monks, representatives of intellectual circles close to the court of King Matthias Corvinus, and scholars associated with the university known as the Academia Istropolitana, established in Pozsony, today's Bratislava.

Some historians of Christianity in the Middle Ages have used the term devotio moderna- "modern devotion," or new piety-in reference to the currents of internal life under abbreviated discussion here. This expression points to notions of piety and devotion that emerged at the end of the fourteenth century in Western Europe-most prominently in the Netherlands and the Rhineland-which were similar in several essential ways to those that I discuss in the context of Central and Eastern Europe. However, a direct dependency of the latter on devotio moderna in the classic, Western sense is difficult to establish. In addition, alongside what are undoubted similarities, we also see significant differences, one of which is an extremely Praguean development (which is also tied to Silesia) started by some of the individuals referred to above, namely a kind of Eucharist-oriented religiousness that was directed at the faithful as a whole.

An essential aspect of this development involved efforts to encourage laymen to take communion more often than usual, even every day, which was an idea borne in Prague in the second half of the fifteenth century that confronted the practice, accepted by the Church at that time, by which it was rare for individuals to participate in the Eucharist. This idea was based on earlier Church tradition, and, as envisioned by Jan Milíč of Kroměříže and his successors, it was to lead to a renewal of Christianity through the internal renewal of the individual. In their 
view, more frequent participation in the Eucharist was an essential foundation of a truly pious life. With laymen in mind, Jan Milíč of Kroměřiže spoke, in one his sermons, the following significant words: "He who appears often at the communion table has eternal life, and he who rarely appears does not, but rather faces death." ${ }^{59}$ The spiritual student of Jan Milíc and continuator of his idea, Matthew of Janow (master of the University of Paris), was even more persistent in this regard, though not without facing resistance from local church authorities (the Prague synod of 1388 banned the faithful from taking communion more often than once a month). Undaunted by the ban, Matthew of Janow argued in his monumental work entitled Regulae Veteris et Novi Testamenti that the best way to restore the old and vital faith to Christians, and to bring them closer to Christ Crucified, was to receive the Eucharist on a daily basis. ${ }^{60}$

The practical-minded Jan Milíc made efforts to introduce the daily communion into everyday life in Prague. His area of action was his "Jerusalem," a community of repentant women (former local prostitutes), for whom constant contact with the Eucharist and associated spiritual care was supposed to put them on the path of Christian improvement. This initiative provoked opposition among clerics in Prague against Jan Milíc and, as a result, Pope Gregory XI had to intervene in 1374 with the Archbishop of Prague.

The belief that frequent communion by the faithful had to be integrated into religious practice was connected, in the eyes of the idea's protagonists, with the notion that that the sacrament was of extraordinary significance and had the greatest dignity. According to Matthew of Janow, the conditions under which a layman would continually receive the Eucharist did not demand an exceptionally saintly life, or one that was difficult to achieve for the average Christian.

Such a devotional trend, which was most pronounced in Prague, spread over time to other lands in Central and Eastern Europe. Matthew of Janow mentioned two priests from the Church of the Holy Cross in Wrocław who held positive views in this regard, and at the University of Krakow, the matter of laymen taking frequent communion was a subject of discussion among scholars at the beginning of the fifteenth century. Stanisław of Skarbimierz pointed to the benefits that came from frequent participation in the Eucharist. That having been said,

59 A. Molnár, "Eschatologická naděje české reformace," in Od reformce k zitřku (Prague 1956), p. 49.

60 Matthiae de Janov, dicti magister parisiensis: regulae veteris et novi testamenti, vol. 5 , ed. O. Odložilik (Prague 1926), pp. 82-83. 
both he and Matthew of Krakow, who favoured the idea of frequent communion, approached the matter with great care.

It is difficult to answer the question to what extent the program of frequent communion resonated among the faithful. Matthew of Janow argued that the number of people who consistently demanded frequent communion was significant, and that that number was consistently growing. However, he lamented the attitude of the majority of Christians, who appeared at the communion table only once a year, at Easter. Matthew of Janow's observations might well have involved, above all, pious woman, particularly Praguean Beguines, who practiced in their convent-like community voluntary poverty and acts of mercy. Evidence also exists to confirm that inhabitants of the Bohemian provinces also had access to frequent communion.

In other lands outside Bohemia (above all outside Prague), there were barely a few individuals who overcame customary practice, and the resistance put up by authorities, and decided to take communion frequently. In the previous chapter, I mentioned the fact that the saintly Dorothea of Montau obtained this privilege, though we must note that she received this sacrament while walled off in seclusion near the end of life in her cell in Kwidzyn cathedral, far from the gaze of other people. According to testimony given by those who witnessed the process of her canonisation, this woman, closed off in her internal world, had always taken communion with great piety and seriousness. Testifying before a special commission, one woman from Gdansk was unable only to say whether Dorothea took the Eucharist in tears, which would have been a sign of particularly exemplary devotion.

Thus far we have talked mostly of individuals. Let us now turn to a symptomatic phenomenon: even members of confraternities in Poland and the Teutonic State (that is, people well acquainted with religious practices) did not see the need to take communion more often than the average city resident. It seems that in Central and Eastern Europe-beyond the exception of Prague, whose actual reach is not well known-frequent communion was not yet an element of deeper piety in the consciousness of the broad mass of the faithful.

Regarding Bohemia, it is arguably the case that the practice of daily communion on the part the laity contributed to the great success of the Hussite postulate to institute communion in two forms: bread and wine. In both cases, laymen had a religious experience as never before, because they were taking part in a sacramental practice previously reserved exclusively for priests.

Setting aside for a moment the issue of lay participation in the Blessed Sacrament of the Altar and excluding the Bohemian Hussites, it is important to point out that the Eucharist-oriented piety of the Christian masses took a 
different direction than that proposed by clerical and reformist elites. We should recall the faithful's desire, discussed above, to gaze upon the host and the fascination they had with the miracles of the Eucharist. Various aspects of the reverential worship of Christ, propagated by the Church, intruded upon mass piety, manifestations of which were the activity of confraternities (which were relatively numerous in Poland, Bohemia, and the Teutonic State) dedicated to the Corpus Christi or the Most Blessed Sacrament; the popularity of semi-liturgical rituals with Eucharistic content; and the great success enjoyed by the Feast of Corpus Christi, particularly in Central and Eastern Europe.

The main emphasis of this holiday is of particular significance, namely the celebratory and hugely popular procession following the host, a procession whose religious content was accompanied by highly visible social content. Such social content was perfectly clear from the moment the procession left the parish church and its churchyard, and moved through city streets and squares past the four altars set up there. In Corpus Christi processions in Krakow, Prague, Wrocław and other cities, organised in grand and exquisite ways thanks to the efforts and generosity of burghers, those who participated, alongside the clerics and crowds of the faithful, were city authorities in corpore and all corporations and communities: merchants, craftsmen, and members of brotherhoods both religious and secular. They carried banners and candles, along with church figures adorned with various crowns. Individuals strove to take up a suitably important position in the procession, one that was close to the monstrance carried by the priest, keeping in mind that the order in which the faithful followed the priest reflected the town's social hierarchy. In the fifteenth century, when church authorities in many cities managed to limit parish processions to a single, central event, the Corpus Christi procession became, to a greater degree than ever before, a demonstration of a local community's identity. It worked this way, for example, in Wrocław where, as the result of a decision by Bishop Piotr Nowak (1451), the great procession moved from the cathedral, across the bridge of the River Oder, to the market square, and engaged a large and important part of the city in its religious ritual. In bi-confessional, post-revolutionary Bohemia, separate Corpus Christi processions were organised by the two Churches, in an attempt to avoid tensions and, at the same time, to ensure the events were properly carried out. Leaders in the Utraquist Church, while not rejecting the secular appearance of processions, urged the faithful participating in Corpus Christi events not to forget about the primacy of the Eucharist's content, which was so important to that community's confession.

When talking about signs of the Eucharist cult, it is worth mentioning that, in Poland and Bohemia, the Church encouraged the faithful, as a group, 
to accompany the priest traveling with the sacrament to those who were sick. This practice was an obligation for members of the confraternities. In Bohemia, this custom was so widespread that Bohemian emissaries returning home from France through Nuremberg were shocked when they saw in that city a priest carrying the host alone.

The spectacular Palm Sunday liturgy involved mass participation by the faithful, the culmination of which was a procession from the church through the streets of the town with the eye-catching "Osiołkiem Palmowym" (a wooden figure of Christ on a donkey, also known in Poland as "Jezusek Palmowy" or, in parts of Germany, as "Palmesel"). The accident that occurred in Wrocław in 1423, when the bridge over the Oder collapsed, several people drowned, and the donkey had to be pulled from the river, did nothing to reduce the popularity of the ceremony.

Mass piety also adopted those forms of devotion that had a powerful influence on collective emotionality and imagination, an example of which, broadly adopted by the faithful, was the worship of the Suffering Christ, which developed intensively in the Church of the Late Middle Ages. Its presence in Poland manifested itself in many spheres of religious life, including in the theology of the time, particularly in tracts by Krakovian scholars on the agony of Christ. In the liturgy, this motif found expression in the worship of the wounds of Jesus, and the popularity of the Mass of Five Wounds was tied to a faith in the special effectiveness of human intentions. The worship of the Holy Cross, mentioned in the previous chapter, was an important religious motif directed by the Church. Lenten sermons on Christ's agony were received by the faithful most fervently when they appealed to their sympathy and compassion. Occasionally, they triggered weeping out loud and cries of grief; once, in the Diocese of Pomesania, church authorities warned the faithful not to disrupt sermons with reactions that were too lively. The suffering of Christ in visual form was one of the basic and most widespread themes of murals and panel paintings. The Christ figure was shown as a Vir Dolorum: Christ standing and displaying his wounds. In the opinion of Alicja Karłowska-Kamzowa, an export in gothic mural paintings:

Mural paintings located in churches in our part of Europe fulfilled a particular conceptual function: to explain the content of the altar tabernacle, where the consecrated Host is kept. The living God, residing in our own parish church, is associated with the suffering Christ-man. ${ }^{61}$

61 Alicja Karłowska-Kamzowa, "Nauczanie obrazowe na ziemiach polskich w XIV i XV w.," in Literatura i kultura późnego średniowiecza w Polsce, ed. T. Michałowska (Warsaw 1993), p. 264. 
It was not only in churches that the faithful were able to view the figure of Christ on the Cross. Increasingly often, crucifixes appeared in the landscapes of several countries, an exception being Bohemia during the Hussite revolution. They could be seen along roads, in wayside shrines, and no doubt increasingly in homes. By the end of the Middle Ages, the figure of the Pensive Christ had emerged, a motif that typified folk culture in Poland (where the figure is called the "Chrystus Frasobliwy"), which depicted Christ sitting, tired and pensive, with head in hand. Through emotion and imagination, the Church tried to inspire a sense of shared suffering among the faithful with the Crucified One, and, in this way, to stimulate regret over sins and a desire to do penance. Polish passion hymns in the fifteenth century, which originated largely among members of the Franciscan order, presented the agony of Christ in a simple and easy-to-remember form, and served as a reminder of that agony practically day after day, hour after hour. Realistic portrayals and detailed descriptions of Christ's suffering were aimed at the religious emotions of the masses, elements for which were found not just in the Gospel, but also in other religious texts, of various origins (including the Apocrypha), that were not officially approved, but were tolerated, by the Church. In Polish devotional meditations from the end of the fifteenth century, which were intended to be read out loud, we find realistic descriptions and suggestive images of the whipping and physical torment of Christ's body, exhausted by torture.

Another devotional thread, at whose centre was the figure of the Messiah, was Christmas, which was celebrated in Western Christianity at a time of the year when, in pagan times, Slavic peoples had celebrated Koliada. As the Middles Ages were coming to an end, this event was tied to the theme of the manger in Bethlehem and the Holy Family gathered around the Christ Child, with the Mother Mary occupying a prominent place. In gothic paintings, Saint Joseph, the old man, was easily robbed of his hieratic dignity. Semi-liturgical performances propagated by the Franciscans included a small stable with an ox, donkey, shepherds and the Three Kings bowing down before the Baby Jesus. In the version disseminated by the mendicant orders, we are also told of the amazing and miraculous events that accompanied the birth of Jesus. Honey flowing from heaven towards earth on Christmas night, the currents of rivers being stopped, the image of Jesus descending, along with hail, somewhere "in Bavarian lands" were all signs that no doubt sparked the religious imagination of the Christian masses. The motif of Christ's humanity, by which the Saviour was brought closer to the faithful, appeared everywhere. Certainly, the worship of the Baby Jesus-inseparably tied to the Mother Mary-was above all emotional in nature. 


\section{The Marian Devotion}

Both remorse-filled sympathy for the Suffering Christ and the joy that came with Christmas, marked by devotion to the Baby Jesus, directed the faithful and their emotions towards the Mother of God. The Marian devotion took on a largely emotional character both in intellectual (and high-culture) religious circles and among the common faithful. Of course, at the end of the Middle Ages, this devotion was not a new phenomenon; it had expanded greatly over the entire course of the Middle Ages, emerging in new forms and finding expression in different terms. Additionally, the fact is that with certain variations this phenomenon was present throughout all of Western Christianity, and if we want to discern aspects of the Marian devotion that were particular to Central and Eastern Europe, then we would do well to search for those qualities not so much in general tendencies, but in particular manifestations. One issue that all the countries under discussion here had in common is the fact that the Marian devotion began to expand and become integrated in mass devotion in the thirteenth century, in connection with activities carried out by the mendicant orders, above all the Franciscans and Dominicans. In the next century, in Bohemia, Poland, the Teutonic State, and Hungary, we can detect shared or related manifestations of the Marian devotion, which testifies to the extent to which it was increasingly established and accepted by the faithful throughout the region.

The Marian direction that devotion took in the cities of Central and Eastern Europe was warmly received by confraternities, whose members were the social elites of large cities, the most admired of which carried the name the Most Blessed Virgin Mary, and who represented the secular avant-garde of that devotional movement. The Marian shrines tied to the brotherhoods in city-centre churches (in Krakow and Wrocław) passed as a point for the worship of the Mother Mary. A statutory obligation for members of a brotherhood was participation in weekly Saturday masses devoted to the Virgin Mary. During Lent, they also participated in morning plainsong masses, known as rorate masses. A new and extremely important phenomenon, one that characterised religiousness in the Late Middle Ages, was the worship of the miraculous image of the Mother Mary: paintings and sculptures. Based on Polish material, at least one scholar has expressed the view that the Marian brotherhoods played a particularly inspiring role in this regard, because images of the Most Blessed Virgin Mary in the brotherhood's shrines were the focus of special worship. ${ }^{62}$ Worship of the

62 H. Zaremska, "Les confréries religieuses à Cracovie entre le XIVème et le XVIème siècle," in Cofradías, gremios, solidaridades en la Europa Medieval (Pamplona 1994), p. 199. 
image of Mary, propagated by members of both parish and monastic clergy, was effective in its penetration of the beliefs and imagination of lay people, because the Mother of Christ approached them through an image or a sculpture; as a person looked upon her image, he or she could turn to her for help in a personal matter. All of this helps explain why those churches and chapels that contained a Marian image which was associated with a miraculous event quickly became focal points for pilgrims.

The Marian devotion in Bohemia, which from the middle of the fourteenth century had advocates among the archbishops of Prague, Arnošt of Pardubice and Jan of Jenštejn, and which had already been spread by monks, was concentrated mainly in monasteries, and more rarely in city churches. At the end of that century, pilgrimages began to grow in popularity, whose destinations were miraculous sculptures (Madonnas of the "beautiful style") or Marian paintings with particular, Bohemian features. In Hussite times, this form of the Marian devotion broke down. Later it began to experience a revival in Bohemia, where it was maintained by the Catholic administration (the demesne of the Rožmberk family extended throughout southern, western and northern Bohemia). New pilgrimage centres emerged, mainly on lands marked by German settlement or in ethnically mixed (Czech-German) areas. Having said that, the Utraquist Church, although it accepted the Marian devotion in principle, did not allow worship of the holy image and took a negative stance towards pilgrimages.

In Poland, the worship of Marian images, which had become quite intense by the fifteenth century and which mainly involved paintings and, to a lesser extent, sculptures, was a phenomenon that characterised the collective religiousness of the country. Only in subsequent centuries did the famous Marian icon of Częstochowa, established at the end of the fourteenth century by Władysław Opolczyk, Duke of Opole, for the Pauline monastery in Jasna Góra, become part of the national sanctuary. According to testimony given by Jan Długosz, set down in 1430, the miraculous painting was already attracting pilgrims "from the entire Kingdom of Poland and neighbouring lands, including Silesia, Moravia, Prussia and Hungary." ${ }^{33}$ However, the few existing records of miracles associated with Jasna Góra from $1435^{64}$ seem to limit the range of these pilgrimages in this period to southern Poland and parts of Silesia. Hungarians also made their way to the

63 Zbiór dokumentów zakonu oo. Paulinów w Polsce, ed. J. Fijałek, vol. 1 (Krakow 1938), pp. 174-175.

64 M. Kowalczyk, “Cuda jasnogórskie spisane w roku 1435," Analecta Cracoviensia 15 (1983), pp. 319-328. 
sanctuary in Jasna Góra, which was the result of the bonds that tied the Pauline monks of both countries. A raid on the Jasna Góra shrine in which the painting was damaged only made the holy place more famous and added an anti-heretical element to the Marian devotion, in light of the fact that there were, in the international group of knights-raiders that committed the damage, representatives of Hussite nobility. The confirmed travels of Polish kings of the Jagiellonian dynasty to Jasna Góra do not indicate that they placed greater importance on this destination over other places in Poland that were greatly revered by pilgrims, but they did set an example to be followed by others, and they raised the significance in Poland of the Marian devotion in general.

The most distinguished centre of the Marian devotion in the Teutonic State, understood as the main devotion for the entire Ordo Fratrum Domus Hospitalis Sanctae Mariae Theutonicorum, or the Teutonic Order, was the Marienkirche in the castle of the grand masters in Malbork. In the order, in addition to its obvious devotional character, the Marian devotion had a countenance that was highly ideational in that it was associated with the Mother Mary on a mission of knights-monks, and with the battle against unbelievers, against enemies of the order, etc. But in the context of the broader population of the Teutonic State, the Marian devotion for expression, for example, in the pilgrimage cult was associated with various miraculous paintings and wooden figures of the Mother Mary: in Malbork, Chełm, Tczew, and several other places.

Advocates of the Marian devotion in Hungary in the thirteenth and fourteenth centuries were Pauline monks, although they were carrying out pastoral duties. Some Pauline churches became Marian sanctuaries that attracted the faithful and found support from the country's leaders (churches in Márianosztra and Salójád were founded in the fourteenth century). In the second half of the fifteenth century, expansion of the devotion became part of the pastoral program of Franciscan Observants. At exactly this time, during the rule of the distinguished King Matthias Corvinus (1458-1490), the Madonna played the role of patron of the country. Defined as the Patrona Hungarie, she began to supplant Saint Ladislaus on coins, who had held a privileged position as the patron saint of the nation. ${ }^{65}$ We can assume that this development was somehow tied to the Turkish threat. Doubtlessly the Marian devotion in general, in the broader Christian world, offered a more resonant contrast to paganism than the worship of the pious knight-king of Hungary, which lacked popularity in the rest of Europe.

65 R. Kiersnowski, Moneta w kulturze wieków średnich (Warsaw 1988), p. 365. 
In every country in Central and Eastern Europe, religious elites set the direction that the Marian devotion would take, the goal being to establish its place in mass devotion. We can attribute the specialisation of this devotion (noticeable from the fourteenth century), and its expansion into new areas, to the initiative taken by the monastic orders, whose members emphasised various aspects of the Mother Mary's sainthood as it continued to take shape: it was tied to the Blissful, the Co-Redemptive, the Mediatory, the Joyous, the Dolorous and the Immaculate, and to the Holy Rosary, etc. Debates surrounding the Immaculate Conception took place as a doctrinal matter and involved, in particular, representatives of the Dominican order and intellectuals from Krakow and Wrocław, but no one participating in these debates renounced the idea that appeal could be made to the faithful through emotions and the imagination. They developed the story of the divine punishment that would be meted out to those who opposed study of the Immaculate Conception, and Długosz's chronicles include the story of a preacher who died suddenly, in front of his parishioners, in the middle of his sermon expressing scepticism about the truth of this article of faith. ${ }^{66}$

While an essential role in the formation and spread of the Marian devotion was played in Bohemia by the diocesan clergy, Cistercians, and Canons Regular under the Rule of Saint Augustine, in Poland it was played by members of the mendicant orders. From the middle of the fifteenth century, an important role was played by the Bernardines; that is, the Polish branch of the Franciscan Observants, as propagators of religious services (later popular) devoted to the Mother Mary known as godzinki (associated with the book of hours). Historians of religious life often emphasise the folk character of Marian devotion in Poland based more its promulgation than on the fact of its less well-known reception. Nevertheless, it seems that those in the church environment who propagated and maintained the Marian devotion were effective in their efforts to penetrate the collective imagination and collective emotions. By presenting the Mother of Jesus at the foot of the cross, they appealed to the faithful's basic knowledge of human suffering. As we know from the array of passion hymns from the fifteenth century, Mary is an unhappy woman trying to ease her son's suffering. The motif of Mary as mother is prominent in texts designed for laymen. In stories drawn from the apocrypha, the reader is confronted with scenes from the life of the Holy Family in which the Mother of Christ exhibits feelings that are common in everyday life: joy, concern, worry. Thus, in Poland since the Late Middle Ages,

66 Joannis Dlugossii Historiae Polonicae libri XII, vol. 3 (Krakow 1876), Joannis Dlugossii 9-10, p. 283. 
the terms used most often to identify Mary are Mother of God and Mother of Christ, and one of those used least often is Most Blessed Virgin Mary.

The Marian devotion in the Teutonic State, which had many of the features of an official devotion, was both different and complicated. The character of the Virgin Mary was given features that were harsher, exultant and authoritative, which were suited to a patron of the chivalrous order. A vibrant motif was Mary meting out punishment to the order's enemies, since they were at the same time her enemies, and the order's territory was her territory. While some historians of Teutonic religiousness have highlighted the military roots of the Marian devotion, others have pointed out the presence of themes associated with feudal ideology. ${ }^{67}$ It remains an open question to what extent the order influenced the content of Marian devotion as performed by the people of Teutonic Prussia.

As the Marian devotion spread, efforts were made to fulfil the expectations of the faithful, who demanded descriptions of Mary's appearance, her customary and daily behaviour, her activities in everyday life, her gestures, her manner of speaking, etc. In a sense, Gothic religious art conformed nicely with the first of these expectations. Marian images entering Poland from the East, which represented the Mother of God with the Baby Jesus and which resembled, in terms of form, the Częstochowa icon, faced barriers put up as a result of relevant canons. Perhaps the "beautiful" Madonnas spoke more directly to the imaginations of the faithful; they were very popular in pre-Hussite Bohemia, although they were criticised by moralists there for being too "secular." Authors of writings known from the apocrypha-more specifically, Polish writings from the end of the fifteenth century-set aside these high barriers and said what readers no doubt wanted to know. They portrayed Mary's external beauty, taking into consideration the appearance of her face, hair, and hands, along with her gestures, gaze, and manner of speaking. Mass religiousness, which tended to anthropomorphise the sacred, found in the Marian devotion a subject that was very stimulating to the imagination, much more so than in the case of the saints, whose external profile was more stiff and conventional. The collective religious imagination turned to Mary as the figure of a concrete woman, who was close to people through features that were easily imaginable and understood, and some of which were drawn from secular ideals. However, in those places where the church authorities, watching over their flock and its religiousness, detected

67 M. Dygo, “O kulcie maryjnym w Prusach Krzyżackich w XIV-XV w.” Zapiski Historyczne 52, No. 2 (1987), pp. 5-36. 
possible desacralisation, barriers were put up. Mary's privileged position alongside Christ, and the depth to which she was worshipped in Christianity, brought in their wake concern on the part of the Church that was no doubt greater than in the case of the worship of saints.

\section{People and Saints}

Human fears, invocations and hope, requests for support in important life matters, were all directed towards a saint, a blessed figure, or towards someone who, though not officially canonised, was in the realm of sanctity. The faithful turned to them with both personal and collective intentions, some of which were spontaneous, some of which were inspired by others. In previous centuries, the Church had taken measures to ensure that the faithful viewed the saints as mediators between them and God, and that they treated them as facilitators exalted in heaven. But it was not easy for people to agree to deprive the saints of their role as sovereign providers of grace. Convinced of the reality of supernatural phenomena, healing processes, and even resurrection, which they could not grasp using the categories of knowledge then accessible to them, and which usually took place in locations tied to a saintly character (in any case, as a result of an appeal to him for assistance), the people were prone to recognise a saint's authority, which might well have been limited in its range, but which was autonomous. It was more difficult to comprehend God's omnipotence through reason and emotion. Mikuláš of Pelhřimova (d. around 1459), a leading Taborite theologian, was no doubt correct when, arguing with his ideological opponents over the value of worshiping saints, he remarked sarcastically that, for simple Utraquists and Catholics, "it seems that the saints are more merciful than God."68

In their collective imagination, the faithful incarnated the saints according to stereotypes; they subordinated them to hagiographical and pictorial patterns, to their knowledge of the holy man's social status, his monastic affiliation, etc. A holy bishop could thus reveal himself to his Polish worshippers as a "venerable man, dressed in a white robe, grey-haired, with a long beard," or simply as a "venerable, grey-haired person." Holy monks emerged using similar lofty attributes, even if they were clothed in the garments of their order. An exultant worshipper, in one of her dreams, saw Saint Bridget, who was the focus of intense worship in the Teutonic State, as a woman "with a beautiful, severe and

68 Confessio Taboritarum, eds. A. Molnár, R. Cegna (Rome 1983), p. 277. 
amazingly kind face," who did not look like a mortal person, but rather "more resembled God than a person." ${ }^{\prime \prime}$

The Late Middle Ages inherited the centuries-old worship of national patrons, among which, in Hungary and Bohemia, were rulers, especially those who had performed great services on behalf of Christianisation, and canonised members of the first dynasties: the Árpáds in Hungary and the Przemyslids in Bohemia. The Hungarian dynasty can boast the greatest number of holy rulers, who, after the first King of Hungary, Stephen, are represented in the assembly of heavenly advocates by his son Emeric and by Ladislaus. Later, other characters joined the pantheon of national saints, at the head of which was Saint Louis of Anjou. In the fifteenth century, the worship of a foreign saint enjoyed great popularity, namely of John of Capistrano (d. 1456), the Italian preacher-missionary, famous throughout the Christian world and promoter of the Observant reformist movement in the Franciscan order.

At the forefront in Bohemia was the extremely persistent worship of Saint Wenceslaus, although the patrons of the Bohemian lands included in the fourteenth century his grandmother Saint Ludmila and other saints: Vitus, Vojtěch (Adalbert), Procopius, and Sigismund. In Poland, where the Piast dynasty had no holy kings, the role of national saint fell eventually to two martyr-bishops from the tenth and eleventh centuries: the Bohemian missionary to Prussia Saint Vojtěch (Adalbert), and Saint Stanislaus (of Szczepanów), bishop of Krakow, who in the Late Middle Ages became the Kingdom's most important patron. In the thirteenth century and the first half of the fourteenth century, the worship of holy princesses, ascetics, and founders of convents and nunneries was characteristic of Polish lands (including Silesia, which was still tied to Poland), Bohemia and Hungary. In Silesia, the worship of Saint Hedwig, wife of Henry the Bearded, was particularly durable and popular among both Poles and Germans. Finally, in the Teutonic State, the role of official cult, promoted by the grand masters, was played-along with the worship of the Most Blessed Virgin Mary-by the worship of the Holy Apostles and Saint Barbara. I have not mentioned here saints whose worship, though on a high level, was simply elite (e.g. dynastic) in nature and was not popular among the broader population.

However, generally speaking society was not indifferent to ties established between the national Churches, the political elites of various countries, and the worship of "national saints." In Hungary, Saint Ladislaus supported Christian

69 Johannes Marienwerder, “Appariciones Venerabilis Dorotheae," in Scriptores rerum Prussicarum, ed. M. Töppen, vol. 2 (Leipzig 1863), p. 368. 
battles against the pagans for the survival of the state and nation. He was represented on the Hungarian ducat as king-warrior and was more prominent in his role as a patron than Saint Stephen himself. His image remained on these coins for an entire century and was later replaced, as mentioned above, by the patronage of the Most Blessed Virgin Mary. Mural paintings from the fourteenth century depicting the life of the holy ruler included the motif, widely known in Hungary, of his battle with the pagan "Cuman" over an innocent Christian girl. The role of defender and supporter of the nation also fell to other holy kings, whose figures-placed outside churches-watched over the borders of the Kingdom of Hungary.

In Poland, in the absence of canonised victorious rulers, King Władysław Jagiełło provided patriotic content to the worship of the Holy Apostles. The July holiday marking their Dispersion (15 July) in the Kingdom of Poland took on the quality of a national-religious holiday of high liturgical rank, one which was associated with the memory of the Polish-Lithuanian victory over the Teutonic knights at Grunwald (during Jagiełło's rule) on the very day in 1410 of the Dispersion of the Apostles holiday.

In Bohemia, the ideational wealth of the worship of Saint Wenceslaus exhibited new content in the Hussite era, during which this national saint became a symbol of Catholic resistance against triumphant heresy, and the revered church hymn "Swatý Vmission" (or the "Svatováclavský chorál") was transformed into a Catholic hymn in Bohemia. Later, other national patrons were bestowed with the rank of defender of Catholicism. Contemporaneous hymns and poems referred mainly to Saint Wenceslaus, but also to other saints, Sigismund and Procopius, and to the humiliation of the Hussites. Many cults of worship, both Church-wide and local, foundered in Bohemia under pressure from the Hussite revolution; to the extent that any of them survived at all, they did so only among Catholics.

Over time, moderate Utraquists accepted into their community the worship of Saint Wenceslaus, which had national significance, and they did the sametreading lightly, so as to avoid idolatry-with the worship of such other saints as Saint Procopius, who was promoted to the honour of being one of Bohemia's patron saints. However, many Bohemian Catholics, not to mention Roman Catholic dignitaries, were alienated by the Utraquists through the latter's officially sanctioned cult of the Hussite martyrs, Jan Hus and one of his chief followers, Jerome of Prague, who was also burned at the stake in Constance. Jan Hus was worshipped as a new patron saint of Bohemian lands, and it was anticipated that a special liturgy would be used in Utraquist churches for the day devoted to Hus (15 July). However, although Jan Hus was, for the large and non-Catholic part of 
Bohemian society, a symbol of ideational-religious and national resistance, his liturgical cult did not become broadly popular.

In turn, Catholics lent an anti-Hussite character to the cults of two famous folk preachers, John of Capistrano (who, during his Bohemia-Moravia mission, violently opposed Hussite heresy) and another prominent Franciscan, Bernardino of Siena.

The Church was careful not to weaken the worship of national patron saints. In Poland, attempts were made to bring the worship of Saint Stanislaus close to the faithful by exhibiting his relics and encouraging people to visit his grave. In Prague, church celebrations of 28 September attracted crowds of worshippers of Saint Wenceslaus, who came not only from the city but from all over the country. An opulent worship service was waiting for them, with tables set abundantly to tempt the poorer pilgrims. What was most effective in attracting crowds of the faithful to churches devoted to a particular saint were the indulgences, the significance of which grew immeasurably in the fifteenth century. Even more, pilgrimages in this century, if they did not represent the path taken by an individual supplicant with a temporal goal, were most often tied to an effort to gain another indulgence, one that was a generous as possible. No one ridiculed an indulgence as a goal, although it was not always enunciated as clearly as it was acted upon by a certain resident from Buda: she had joined a pilgrimage "out of devotion" and travelled, along with other women, to various places in Hungary, "to obtain indulgences."

The worship of saints took shape and developed around their relics, and in the context of mass devotion, the holy person was often identified with his mortal remains. ${ }^{70}$ In records of testimony provided concerning the miracles of John of Capistrano, who died of the bubonic plague and was buried at Ilok on territory then controlled by Hungary, we read statements that confirm the abovementioned identification: one worshipper of the saintly man testified that she visited his grave because she had not been able to meet him in life. Another pilgrim spoke of vows given "to the body of a holy man."

I mentioned above that the worship of saints gave people the possibility of choice. The fact-one that characterised piety and devotion in the Late Middle Ages-that saints were specialised as facilitators and protectors of people in various situations, particularly those who were ill or infirm, was accepted without reservation in the countries of Central and Eastern Europe, with the exception

70 G. Klaniczay, "Le culte des saints dans la Hongrie médiévale (Problèmes de recherche)," Acta Historica Academiae Scientiarum Hungarica 29, No. 1 (1983), p. 68. 
of Hussite Bohemia. We thus know that Saint Sebastian and Saint Roch provided protection against the plague; Saint Valentine "healed" fevers; Saint Apollonia healed tooth pain; Saint Lucy healed eye pain; and other saints helped people suffering from other ailments. Various saints served as defenders and facilitators in other important matters of human existence. Saint Florian protected against fire and flood, and Saint Vincent and Saint Medard were responsible for good weather. The worship of specialist saints arrived from Western Europe in various ways which were not always simple. Hungary provides an example of how German colonisation extended into this sphere. ${ }^{71}$ The local saint, from person's home town or region and thus nearby, was often the common choice, and in this regard it was extremely significant that such cults were propagated and supported by people involved in the local church. Particularly when pilgrimages developed around them, these cults encouraged popular devotion, which manifested itself in various beliefs and practices, although such devotion was, in a certain way, limited and circumscribed. Fifteenth-century Cracovian cults, associated with several people who had died with the odour of sanctity, diocesan and monastic priests, share many of the features that mark just such a popular devotion, even though they were guided by the clergy. These cults turned to local saints, who in some cases were well-known to locals as priests and preachers. The influence of these cults did not reach far beyond Krakow and the Cracovian diocese. Another possible option was to discover the correct holy man; that is, the one who would be the most effective in helping people. In key life situations, most often when one (or one's relative) was ill, the miraculous powers of several saints would be tested by visiting, one by one, each of the sanctuaries tied to their miracles. Pilgrims believed in the special and privileged power of the places in which holy remains were located, or in which a saint's relics were preserved, and were thus not deterred by failure. Along the path of these journeys of hope and disappointment, we find loca sacra that were more or less popular at the time and that enjoyed the Church's approval. Those who found grace at the beginning of the fifteenth century during their pilgrimage to the grave of Dorothea of Montau at Kwidzyn included many who had already visited, with the same goal in mind, the Church of the Most Blessed Virgin Mary in Pehsken, the Church of the Holy Cross in Stroesburg, and "various places in which saints were worshipped." ${ }^{2}$ In Hungary, one woman from Buda made her way first to Báta and then to Pécs in

71 G. Tüskés, E. Knapp, “Europäische Verbindungen der mittelälterlichen Heiligenverehrung in Ungarn," Analecta Bollandiana 110, No. 1-2 (1992), 50 ff.

72 Die Akten des Kanonisationsprozesses Dorotheas von Montau, p. 342. 
order to reach, in the end, the grave of John of Capistrano in Ilok. A noblewoman from the Diocese of Krakow set out on a pilgrimage to one location after another, all of them prestigious in Poland: first to Jasna Góra near Częstochowa, then to sanctuaries in Małopolska: to Christ's Passion in Miechów; to Saint Stanislaus in Krakow at Skałka; to the Holy Cross in nearby Kalwaria; to Saint Bernard's behind the walls of Krakow; and to other places closer to home, unknown to us, until she finally found her "own" holy man in the person of the blessed Cracovian Bishop Jan Prandota, who satisfied her request. Other members of the flock more quickly found saints whose miraculous powers they recognised. Those who did not receive the expected grace left one miraculous location, no doubt most often out of humility, in order to move on, with continued confidence, to the next location. We also read about behaviour that is somewhat less uplifting. Petrík, a resident of Prague who, in Wilsnack, had put up a silver hand as a votive offering but did not gain the desired result (healing), declared the sanctuary there, which was famous at the time, a fake. ${ }^{73}$ At the same time, he regarded the priest, who had convinced the faithful that votive offerings would be effective, a liar.

In the context of mass piety, the power to perform miracles was the most obvious and widely recognised indication of a saint's strength, while faith in his potential was a prerequisite for the proper attitude towards the holy nature of his character. In popular beliefs and the popular imagination, relationships between the people and saints were nonetheless rather complicated, and were occasionally marked by suspicion, a lack of trust, and irritability on the part of the saints, which was shown most powerfully by those saints who had not yet been canonised but were worshipped zealously in the area where they had been active, or where they had died in the town or city, in the diocese, or in a defined region of the country. The faithful were obliged to show loyalty to them no less than they would to saints that were officially recognised by the wider Church. Any person who doubted the power of a saint to perform miracles could not only not count on his or her mercy or assistance, but would also have reason to fear the consequences of the saint's outrage and anger. A certain "worthy man" from the Hungarian diocese of Veszprém, who under the influence of others doubted the sainthood of princess Margaret, fell ill crossing the Danube and returned to health only slowly. ${ }^{74}$ Those who explained the experience of being healed using

73 F. Šmahel, "Stärker als der Glaube. Magie, Aberglaube und Zauber in der Epoche des Hussitismus," p. 321.

74 K. Bölle, Árpádházi Boldog Margit szenttéavatasi ügye és a legősibb latin Margit-Legenda, p. 37. 
"common sense," and who attributed the process to the assistance provided by a physician rather than by a saint, did not believe in the saintliness of a person who had not yet been canonised; in a nutshell they doubted miracles, and they thus faced punishment in the form of recurring sickness, disability, or some other misfortune. Punishment also awaited those who neglected to keep the vows they had made to the saint, vows which essentially represented a contract concluded between a person and a saint.

In the imaginations of the simple faithful, saints and holy men not only expected homage and proof of faith in their powers, they were greedy for it, given that they did not want to lose a single worshipper. A woman from the Hungarian town of Szeged called out, in suffering, to John of Capistrano: "Blessed father, help me, because I want to visit Your grave." While many attempted to assure the saints of their faithful devotion, others-who were aware of the saints' "ambitions"-declared conditional faith in their saintliness. A burgher from Gdansk thus turned to Dorothea of Montau and said: "Oh, most blessed Dorothea! If, through your services, you obtain health for me from God," (this part of the invocation might well come from the pen of the person recording the testimony), "then I will gladly believe in your saintliness and I will always worship you as a saint." Once, when Helwigis from Gdańsk was travelling by boat on the Vistula River and one of the paddlers fell overboard and began to drown, she cried out to Dorothea to save him: "If you do this, I will believe fully in Your saintliness and in everything they say and preach from the pulpit about you, but if he drowns, then I will never believe in Your saintliness." 75 What we see here is thus a kind of "blackmail" of a saint, with certain "conditional" prayers resembling a threat. We have thus diverged far from the model attitudes as taught by the Church, according to which one owed a saint unconditional reverence and trust. These were not the only such divergences.

Saints demanded that petitioners follow through on the pledges they had submitted in need, but they were not particular when it came to their quality. Beyond the pledged pilgrimage to a saint's grave or relics, a person could-or even had to-offer gifts from defined categories that depended on the individual's means and generosity. Rarely were these gifts spiritual in nature, in the form of prayer or mortification; more often, they were symbolic objects, or objects associated with the practice of the saintly cult (candles and formed wax). The faithful left objects, "exvota" of either wax or silver, as visible signs of gratitude for a return to health, or reminders to the saint of his or her obligation. Pilgrims would frequently

75 Die Akten des Kanonisationsprozesses Dorotheas von Montau, p. 104. 
place images of a healed body part at their destination: a hand, a foot, or an eye, carved out of wax or ore. Occasionally, they brought a formed wax object corresponding to the weight of the donor, or wax statues representing a person that were sometimes of a height equal to the person who had been cured, or a candle of similar height. A certain woman brought to the grave of Dorothea of Montau "a candle the same height as the girl" who had been healed. The huge wax candle had been hauled to Ilok as an offering to John of Capistrano. From the many gifts that the blessed Prandota, Bishop of Krakow, received from his worshippers, one that was placed at his grave by a wealthy Cracovian burgher was extraordinary: "a wax figure and four enormous candles corresponding to his height, on which half a block of wax was used."76 The saint was offered figures representing healed animals that were important to an individual's very existence, for example horses and cows. Among the votive objects found in Moravia, in a place where a church once stood that was dedicated to Saint Leonard, the patron saint of livestock, there were miniature horseshoes and sheep shears. A highly original set of votive offerings was recorded on lists prepared in the fifteenth century in Starogród in the Teutonic State, more specifically in the chapel of Saint Barbara, where her miraculous relics were preserved. These exvota are testimony to the kind of eclecticism that characterised her cult. It was one of the most important cults in the Teutonic Order, but it was also widespread throughout Europe as the cult of the patron saint of non-violent death, and the guardian of souls in purgatory. It also happened to be the local cult of Pomeranian fishermen, raftmen, and sailors, who saw in Saint Barbara their protector. Such valuable objects could also be found in the church at Starogród: crowns, rings, belts, coins; exvota as mentioned above, in the form of silver arms, legs, eyes, hearts; and finally-and probably the most interesting to us-objects that were an expression of the piety of simple local people, which were placed there out of gratitude to the saint for having saved lives in an occupational hazard (or for a good catch of fish): "item boben dem howbte Sente Barbare eyne snuere vol czeichen von sylbern bebylde von heringen, awgen, herczen, satele, fyschen, schiffe, ingegraben bilde und derglich." ${ }^{\prime 7}$ Residents of the castle of the grand masters at Malbork, the headquarters of Teutonic commanders and wealthy and powerful knights, were connected

76 Miracula Venerabilis Patris Prandothe, in Monumenta Poloniae historica, vol. 4 (Lvov 1884), p. 476.

77 Das grosse Amterbuch des Deutschen Ordens, ed. W. Ziesemer (Danzig 1921), pp. 514-515. T. Mroczko, "Czerwińska herma św. Barbary," Studia Źródłoznawcze. Commentationes 19 (1974), pp. 99-100. 
through the figure of the saint by the shared objects of the cult, although the intentions associated with him were usually quite diverse.

Quite separate from the matters we have discussed above, we can detect here signs of deep religiousness in the attitudes of the human collective that turned to saints for assistance. We can identify prayer accompanied by internal experience, faith that a person's petition would be heard, and gratitude for grace. However, equally important and characteristic are phenomena associated with form, ritual and gestures. I spoke of some of them when I took up the matter of prayer. But other gestures were also used, such as the universally recognised practice of touching the saint's grave. People believed in its immediate effect: the epilepsy that had afflicted a boy from the Diocese of Esztergom for years disappeared immediately after he visited the famous island of Saint Margaret and touched the blessed one's grave. They also kissed the saint's grave or, if possible, his body before it was buried; in Hungary, worshippers of the adored Father John of Capistrano did this. In the sources, we often read of healed children being brought to the sanctuary so that they could be "shown" to the saint out of gratitude. In the list of miracles performed by John of Capistrano, we read about the interesting ritual, which itself is worthy of further attention, of visiting the saint's grave three times, the goal being to obtain miraculous healing. Knowledge of the unwritten rules regarding gestures and rituals and their observation were understood by the faithful as an essential condition for having their needs fulfilled. Records of testimony about miracles from the Late Middles Ages, edited by representatives of the Church, did not distinguish all of these attitudes and practices; they neither concealed them nor obscured them, and they did not alter the story of those instances of mass devotion that had not wandered too far from the path charted by the Church.

Most of my considerations so far have touched upon the religious attitudes, beliefs, and perceptions of people of the Catholic faith. Discussing Bohemia, I focused mainly on the pre-Hussite period and, in a small way, on the times marked by the coexistence in Bohemia of the Catholic and Utraquist communities. 



\section{Folklore under the Influence of Christianity}

We have already touched upon on matters that testify to the interaction of Christian and traditional world views, with the latter involving the beliefs, attitudes and practices of local folklore, which were above all-but not exclusively-rural in nature. Such interaction occurred throughout all of Christian Europe, although it was naturally marked by national and regional differences; indeed, in Central and Eastern Europe, where Christianity was not as deeply rooted as it was in Western Europe, these interactions had particular qualities that are not always easy to grasp. Our next considerations will be based on examples from Poland and Bohemia, which shared the legacy of an old Slavic culture that was, in a certain way, very much alive in the Late Middle Ages, despite instances of obvious cultural stratification and the presence of foreign ethnic influences (tied to, for example, German colonisation, which was substantial in both countries).

\section{The Church and Folk Tradition}

As mentioned above, cultural historians of the Late Middle Ages have rejected the notion of the so-called remnants of paganism, against which Polish and Bohemian theologians had once zealously battled; scholarship indicates that the pagan religious system died out among the Western Slavs in the High Middle Ages. Indeed, various later Church sources-including diocesan decisions by the synods, questionnaires associated with bishop visitations, and sermon textsindicate that their authors turned harshly against simple people practicing the cult of pagan gods or worshipping trees or bodies of water. However, what is involved here is a long-standing Church tradition tied to the old battle against what were in fact relics of paganism. The contribution of local realities in this tradition is a matter of debate. The conceptual apparatus of the above-mentioned texts refers to an old, extinct (and often unfamiliar) reality, and was in part identical with terminology present in scholarly works from the Early Middle Ages. Beyond this, the names of Slavic gods and demons, who were cited especially by Polish theologians in the fifteenth century and who were once widely worshipped, were often seriously distorted; the sound of those names was based on uncertain information handed down through generations and was surely no longer understood by anyone. Nonetheless, the names of these gods from the old Slavic pantheon, whose authenticity is now a matter of guesswork, are known to 
us from written sources from a much earlier age. We also find certain (more or less) traces of these names at various levels of our vocabulary, for example in the names of towns and cities, including the presence of the root vol, or vel in certain names (as in the mountain massif Wołoszyn in the Tatras, associated with the legend of a dragon by that name, and the island Wela or Weler, once a place where sacrifices took place at one of the Pomeranian lakes), which appear to be a vestige of the ancient cult of Veles, the god of prosperity, fertility and vitality.

We might add that theologians and chroniclers were eager to ascribe a pagan origin to certain particularly folk rituals and practices that were, in various regards, unauthorised by the Church. At the time, such terms as "relics of paganism" and "pagan traditions" were nothing more than instruments of polemic rhetoric, which, after all, in the fourteenth and fifteenth centuries had a refurbished terminology. These terms and other similar ones had not so much been forgotten; rather, they were losing their dominant significance and their role as the universal key to interpreting and evaluating folk culture. In any case, as late as in the middle of the thirteenth century, the Cistercian Rudolf, from a monastery in Rudy near Raciborz, author of a confessional handbook ${ }^{78}$ that was rich in evidence of folklore traditions taken, in part, from age-old writings, observed illicit superstitious and magical practices being carried out by his simple penitents, German residents of Silesia, through the prism of the vitality of pagan cults.

The Church continued to look upon local folk culture with reserve and antipathy. Such an attitude, which was present in varying degrees throughout all of Europe, allowed Christianity in Eastern Slavic lands to be explained by a different, younger metric, and thus by a more vital and readily accessible memory of the pagan past. Creators of diocesan statutes and authors of theological tracts and sermons, in their desire not to abuse the stereotypical formula "remnants of paganism," replaced it with other terms that were more suited to their polemic and didactic goals. In this vocabulary, the main role was no doubt played by a notion well-known since the Early Middle Ages, namely "superstitiones," though there was often also talk of errors ("errores") in faith. Both of these terms overlapped conceptually, and they described phenomena that were both numerous and varied. As viewed by Polish and Bohemian theologians, folk magical practices were examples of superstition and error: magic employed to heal or prevent disease, to ensure a good harvest or bring prosperity; the use of amulets and consecrated objects and Christian symbols for mundane purposes; practices

78 Katalog magii Rudolfa. Źrodło etnograficzne XIII wieku, ed. E. Karwot (Wrocław 1955). 
not approved by the Church but associated with worshiping saints; various kinds of augury, etc. Through theologians and preachers, the Church harshly condemned all of these examples of delinquency against the purity of faith and devotion, but it also employed simple, easy-to-understand arguments that were doctrinal and ethical in nature, but also practical and reasoned. The goal was to show the faithful that such transgressions were a source of sin and offensive to God, and that they were ineffective and senseless. We can detect here a symptom of the Church's new attitude towards the broader masses of the faithful, who could no longer be treated simply as a passive society, the mere object of dictates and prohibitions. In any case, the attitudes of Church representatives, particularly of pastoral theologians who had contact with the world of folklore, were extremely diverse. Some of them took a moderate stance, in an attempt to distinguish between harmful activities and those that could be tolerated, and in their battle against "errors and superstition," they made use of not only threats but also the above-mentioned argumentation. Such a moderate stance was taken, for example, by the Cracovian theologian Stanisław of Skarbimierz, author of several sermons on superstition, which are remarkably valuable as the most extensive record of the practices and rites of folk culture in Poland at the turn of the fifteenth century. ${ }^{79}$ Earlier, in Bohemia, Stephan of Roudnice (d. 1365), while discussing various folk rituals, customs and practices, tried to draw a distinction between what was objectionable and prohibited, and what was allowed. ${ }^{80}$

Advocates of reformist movements, beginning with Jan Milíč of Kroměříže, who wanted to cleanse evangelical Christianity of its human "flaws," were averse to any non-biblical traditions, and treated with outright hostility those attitudes and actions that, in their view, distorted the model worship of God. Hence, they were harsh in their condemnation of those examples of "superstition" that other clergymen treated leniently. At the same time, they were more tolerant than the radical Hussite preachers, who-in the name of the moral rigor that was obligatory for "adherents of the divine truth"-regarded religious traditions, folk rituals based on religious motifs, local traditions, etc., as harmful and sinful. For a period of time, they managed to muffle traditional culture, at least its external manifestations, but in those areas where Hussitism failed to take root in rural

79 Stanisław of Skarbimierz, Sermones Sapientiales, ed. B. Chmielowska, vol. 2 (Warsaw 1979), pp. 82-94; idem, Sermones super "Gloria in excelsis", ed. R. M. Zawadzki (Warsaw 1978), pp. 103-105.

80 The Quaestiunculae of Stephan of Roudnice, ed. R. Zeleny (Rome 1966), pp. 108-122, 236-283, 272-405 (reprint from Appolinaris 38 [1965]). 
societies, elements of traditional folk culture eventually returned, including ageold rituals, the practice of magic, and superstitions. In the Utraquist Church, the battle against these elements of folk culture became one of the most important aspects of sermons designed for the people. Jan of Rokycany constantly admonished his flock, stating bitterly: "Yes, society among these people is full of superstition." ${ }^{81}$ The issue of the relationship between reforms in Bohemia in the fourteenth and fifteenth centuries and folk tradition and folklore are interesting and extremely important, but they have not yet been adequately researched. In any case, currently we will set aside the matter of the Hussite context.

The countries of Central and Eastern Europe in the fourteenth and fifteenth centuries made up a world that was still, for the most part, traditional and agrarian in nature. This world was based on the co-existence of people with nature. It mainly included rural populations and residents of towns, although it also reached into cities through the influx of people from the countryside, particularly in areas that amounted to suburbs in the Middle Ages. A great deal of source evidence confirms the presence in urban societies of folk rites and rituals that, given their content and symbolism, we would tend to associate with the countryside. A list of questions put together by Bernardines (Franciscan Observants) in Poznan, and intended for suburban confessors, also addressed "superstitions" that reached deeply into the beliefs of agrarian society. ${ }^{82}$ The use of un-schooled folk magic, the important goals of which involved the health of people and their livestock, and more broadly the well-being of the household, its inhabitants, its surroundings, and its equipment, lasted until the end of the Middle Ages and in some places far longer. In agrarian societies, the transfer from one generation to another of practices establishing contact between the individual and nature did not cease. Through these practices, people tried to gain nature's favour, to ensure crop growth, a good harvest, and success in the other endeavours of people living close to nature. They attempted to protect themselves against nature's threats, which were both numerous and usually unpredictable. Divination was practiced using generally available and widely known techniques quite independently of a "qualified" individual. A person's fate could thus be predicted, including life and death in the family, material success, and marriage. Divination was an additional but important element of traditional annual observances. In the springsummer season, culminating on Saint John's Eve, divination was practiced in the

81 Postilla Jana Rokycany, vol. 1, p. 748.

82 J. Wiesiołowski, "Problemy społeczne klienteli bernardynów poznańskich," in Franciszkanie w Polsce średniowiecznej, vol. 1, ed. J. Kłoczowski (Lublin 1983), 350 ff. 
open air, especially over bodies of water, when it was easiest to reveal the future's secrets. Beyond that, various traditional attitudes and ideas, often no doubt with pre-Christian origins, showed themselves to be extremely durable; they proved difficult to uproot and, at the same time, adept at coexisting with the superficial layer of religion as taught by the Church. In other words, for the broadest mass of people, Christianity in the Late Middle Ages merged "with the local world of culture and folklore into a kind of whole, more or less integrated." ${ }^{83}$ The kind of folk religiousness we are discussing here was precisely the result of this process. The matter can be viewed in two ways: as the assimilation of some of the superficial aspects of Christianity into folk culture, and as the subordination (or "bending") of certain rules in Church liturgy and ceremony to the traditional patterns of thinking and feeling that characterised agrarian societies. In historiography, these phenomena are usually defined as the "Christianisation of folklore" and the "folklorisation of Christianity." In discussing the first of these two concepts, my focus will be not so much the Church's influence on folk culture and its conscious substitution of old traditions with new ones, but rather the deeper dynamics at work in folk religiousness, regardless of external inspirations.

\section{Beyond the Influence of Christianity}

Firstly, we should note that the influence of the Christian religion did not cover all traditional rituals, and one that largely avoided the Church's influence involved popular magic practices. Reading that part of Rudolf of Rudy's confessional handbook that was devoted to magic and superstition (the "Catalogue of Magic"), we note that "Christianised" magic; that is, the kind of magic associated with consecrated objects or a period in the liturgical calendar, played a fairly small role in the Cistercian's scholarly work. Magical practices tied to love and marriage, healing, and assurances of prosperity and abundance in the household rarely penetrated the sphere of issues tied to the Christian religion. The extent to which this source is a factual representation of the folk culture of Germans in Silesia, and the extent to which it provides an anachronistic image as might be indicated by author's citation of the names of ancient and Germanic gods and mythical beings, is a question that has yet to be answered.

If we look at traces of the old Slavic calendar of rites, which can be identified in the Polish and Bohemian sources of the fourteenth and fifteenth centuries, we note that ceremonies and rituals extracted from ancient contexts, and reflecting

83 J. Kłoczowski, Europa słowiańska w XIV-XV wieku (Warsaw 1984), p. 184. 
certain traditional beliefs and patterns of behaviour, remained vital. They included an early-spring rite, practiced on the fourth Sunday of fasting, known as "lethal" Sunday, which involved carrying an effigy representing winter's death beyond the edge of the human settlement and immersing it in water or mud, and which highlighted the motif of the departure of winter, tied to the death of winter. The effigy was called Marzanna, Mara or Marena, which in West Slavic languages have an etymological connection with death (mór). This ritual faced powerful opposition from the Church in Poland and Bohemia, which helps explain why it is well-documented in the sources; it was tied to the traditional belief that it was possible to push back a threat, or an evil, through the collective human action of carrying it beyond the border of human settlement.

Another example of a rite that was resistant to Christian influence appears to be the Kupala Night, which was associated in principle with the midsummer (thus, with the date 24 June, Saint John's Eve), but which had variations on other days in the spring ceremonial cycle. This event, which featured a communal bonfire that the Church ineffectively opposed, was rich in content and symbolism. The layer of Kupala Night that is associated with water includes auguries of various kinds, the most prominent of which involves the release of wreaths in a river or stream. The name "Kupala", which is more widely known in the Slavic East than in the West, is tied etymologically to ritual river bathing (the Polish verb "to bathe" is kapać or kapać się). There was a cleansing character to these rites, but they also contained themes of fertility and harvest. And, as recent Russian scholarship indicates, they were tied to the influence of demonic beings, and particularly to a category of souls of the dead, namely those that threatened the living-mainly the souls of those who had drowned.

\section{The Content of Annual Rites}

Both of the rites briefly discussed above were among the most important elements of the annual cycle. Later we will discuss other ceremonies and rituals that maintained their independence. Returning now to the mutual penetration of the two traditions, we find ourselves still in the sphere of annual rights in which the Christian version everywhere was imposed on the traditional holidayritual structure. One historian of Christianity in the Middle Ages, attempting to characterise this process, discerned that which was the culmination of the coexistence of the two systems:

The deeper meeting of Christian tradition with ancient pagan traditions occurred on the bases of rituals observed in the family-household, and of the calendar of holidays that made up the annual cycle of peasant activities according to the rhythm of the four seasons 
that was so important to peasant culture. Christian interpretation was intertwined with ancient customs that the Church (generally speaking) handled without hostility, which at the same time implemented an educational program designed to eliminate magical elements (spells and divination) and ludic elements (amusement) [...]. At the centre of this calendar was the ancient holiday of Koliada, today's Christmas [...]. The Christmas Eve supper, which was Slavic in origin, dated back to the ancient holiday of prosperity and good fortune, celebrated along with the souls of deceased ancestors. ${ }^{84}$

Let us pause for a moment to discuss the folk celebration of Christmas, which replaced (though not entirely) the winter-time Slavic holiday Koliada. In this case as well, the coexistence of the two traditions does not appear to have been without conflict. In Poland, Church authorities tried to root out a part of old holiday rituals by prohibiting "amusement and superstitious beliefs on Christmas Eve, which—unfortunately! - have spread throughout this country." We cannot be certain what amusements and customs so offended the creators of the Poznan synodal statues from $1376,{ }^{85}$ whose content was echoed in later years. But the texts of other synodal statutes allow us to presume that, behind the wide range of enigmatic terms, were hidden a number of local variants of spectacles also known in the West, in which participants danced in churches, and around churchyard cemeteries, covered in masks and animal skins. By contrast, the Church approved of the use of the folk name "Generous Eve" (in Polish, Szczodry Wieczór, referring to munificence, abundance) and all of the customs and practices associated with it. Jan of Holešov, a Moravian Benedictine, who in 1400 authore a treatise devoted to Bohemian-Moravian Christmas Eve customs $^{86}$ (which Jan divided into good and bad, between those that were "honourable" and "worthy," and those in which the devil was a participant), displays a clear tendency towards the "Christianisation" of old rituals. In his view, the name "generous eve" is a reference to the generosity of God, who on that night gave the world His Son. What also comes to mind is the miraculous abundance of Christmas night, on which honey flowed from the heavens. We have thus come upon the trail of a "new" tradition, one that is certainly not of local origin. We see in Bohemia and Poland that version of Christmas Eve abundance that is associated with the motif of rivers flowing with honey and wine, well water being turned into those noble drinks, trees flowering in the gardens despite the

84 J. Kłoczowski, Dzieje chrześcijaństwa polskiego, vol. 1, 99 ff.

85 J. Sawicki, "Najdawniejsze statuty synodalne poznańskie z rękopisu BOZ 63," Studia Zródłoznawcze. Commentationes 1 (1957).

86 Largissimus vesper seu Colledae Historia authore Joanne Holeschoviensi, ed. A. T. Fasseau (Olomoucii 1761). 
winter weather. Traces of this motif in Poland seem to lead to the mendicant orders, which spread that kind of myth. However, Jan of Holešov raised the dignity of the Christmas Eve custom of extending best wishes (to family members and friends), which would seem to be a reference to the generosity of God. In turn, the act of bringing straw into the home and spreading it throughout the rooms commemorated, according to Jan of Holešov, the place where Christ was born, in the Bethlehem manger, in a crib in the hay. Jan's "Christian interpretation" of folk customs occasionally seems dubious, including when the author bases his argument on the testimony of "old and worthy people" (at this point, we might note that, in various texts of Church origin, the figure of the old person appears as a narrative source that is often used to indicate folklore). However, the comments put forward by Jan of Holešov, a keen observer of folk rituals and the beliefs tied to them, seem to confirm the penetration of local folk traditions by those aspects of the Christian tradition associated with Christmas Eve. At the same time, the author had no doubt that part of that folk tradition maintained its delinquent, even condemnable, non-Christian autonomy. In his list of bad customs (because they were pagan), the Moravian Benedictine included various auguries and magical practices, one of which involved placing loafs of bread on the table so that, on Christmas night, the pagan gods; that is, demons, could eat them. Around a half century earlier, in Silesia, Rudolf of Rudy reprimanded simple penitents for having attempted, on Christmas Eve, to receive, and offer food to, a mythical figure known as domina holda.

The long cycle of traditional spring rites, to a large extent associated with the beginning of plant growth, revealed itself in those dates that became important in the liturgical calendar. We have already come across the term śródpoście (mid-Lent), which came on the threshold of winter and spring, when winter is melting. What then followed was a true assemblage of rituals, tied to the Holy Week of Easter. It was then, on Maundy Thursday (and occasionally on Holy Wednesday), that efforts were rightfully made to receive the dead souls as guests and to seek their favour. The ritual blessing of food, including eggs, in church seemed to replace ancient magical practices focused on food. The blessing of fire on this day indicates the Church's intention to Christianise that traditional springtime rite that was tied to fire, because we discover here a ritual involving a fire started with stones and a procession that circles the fire burning in the church cemetery. The church ceremony certified specially for the Wrocław cathedral in the fifteenth century rivalled, in a certain sense, the folk ritual of starting a "new," "holy" fire in the spring with the help of special, though simple, equipment (a świder ogniowy, "fire auger"). Inspiration provided by the Church did not present a barrier to the popular reaction to 
rituals carried out within the liturgical framework: the faithful took home smouldering remnants of the fire, blessed by the priest, where those remnants would be re-kindled so that, should there be a storm, the household would be protected against lightning.

Springtime processions in the fields are a good example of the two-sided Christianisation of folklore: voluntary and spontaneous, resulting from initiatives taken by villagers, and "from above", as carried out by the Church. At the beginning of the fifteenth century, Stanisław of Skarbimierz, discussing the inhabitants of Poland and their superstitious rituals, noted that "they walk through the fields with a cross, doing so not out of devotion but out of mistaken faith." This agrarian ritual, practiced on Easter Monday, more often collectively than individually, no doubt represented the continuation of a pre-Christian tradition, which in the Early Middle Ages was also practiced in Gaul; according to Sulpicius Severus, people around Tours carried likenesses of idols through the fields, the goal being to encourage soil fertility and to ensure a good harvest. We do not have similar evidence at our disposal regarding Western Slavic lands. The magical content of the rite was preserved in the ritual of circling the fields, which themselves became objects entrusted to supernatural powers. The Cross in the hands of participants was an obvious sign of the presence of Christianity; we do now know if Polish peasants, during this ritual, said the prayers they had learned in church, or if they uttered some sort of ancient magical text. It seems that Stanisław of Skarbimierz knew nothing regarding this matter, although he was shocked by the "self-sufficiency" of the folk ritual, carried out with the presence of a priest, even though the Church had long been aware of the spring processions known as rogationes, during which a priest led a procession to bless the fields and pray for a good harvest.

\section{"Christian" Magic in Everyday Life}

The Christianisation of folk rites and practices, a process that was based on the absorption and internalisation of certain external, liturgical religious forms, also took place in everyday life outside the annual ceremonies discussed above. An expression of this Christianisation were the texts uttered by simple lay people in their mundane intentions, and modelled on church blessings (benedictiones) and exorcisms, which were viewed by some of the faithful as magical practices. Opposition to these practices emerged at the Synod of Prague in 1349, where it was decided that priests would be obliged to inform the church leadership of the presence in the parish of individuals attempting, through the use of certain words, whether spoken or written (below, I will discuss the role of the written 
word in magical practices) to cure people or animals, to ensure fertile fields and trees, and to counteract violent storms, lightning, and hail. ${ }^{87}$ The list of such practices also involved one that was well-known to priests, namely the blessing of cattle and sheep to protect the herd against attacks by wolves and bears. The Bohemian author Stefan of Roudnice noticed that priests, in their blessing of animals under their care, circled the herd three times and said the following words out loud: "Not established by the holy canons."

In various pastoral texts, particularly in sermons battling errors and superstitions committed by common folk, authors condemned and mocked the crass "womanish blessings" usually offered for curative reasons. Stefan of Roudnice, who was more tolerant than other theologians in this regard, put thought into the value (and admissibility) of "womanly blessings" made against headaches, tooth pain, eye pain, and bleeding. These blessings in verse form (verba ritmice composita), after all, usually contained no reference to anything that offended, or ran contrary to, the faith; on the contrary, they included references to the Holy Trinity and to the words of the Lord's Prayer and other prayers. The permissive response (in certain circumstances) from the Bohemian author is not what is most important to us here. We can assume that, although he maintained certain doubts, he also understood the people's true attitude, in which-they were convinced-various traditional practices were reconciled with professed religion.

One Polish author of a sermon from the first half of the fifteenth century, in opposing attitudes and practices that he regarded as superstitious, quoted what presumably is the defence put forward by a person accused of one such offence (or perhaps the author gained this knowledge through confession?):

I believe in the single God and do not use signs, auguries or prophecies. But if I become ill, if fear overwhelms me, if I become infirm, if I sense an inadequacy, or if I fear for the things that I possess, then I give praise, I show devotion, I use divine words and I do everything in the name of Our Lord Jesus Christ, and if I do so in the name of the Lord, then I do well. Hence, when I ladle out wax or lead, when I try to look into the future, I call on God; when I approach a sick person, I speak the word of God, and when I try to cure an animal without knowing how, I use the sign of the cross; when I place amulets (plicaturas et ligaturas) on a child so that it would know no fear, I do so in the name of Jesus [...]. If, in my search for success, I utter a word in praise of God [...], I do it all in good faith. ${ }^{88}$

87 R. Zeleny, Councils and Synods of Prague and their Statutes (1343-1361), p. 21.

88 A. Brückner, Kazania średniowieczne, part 1 (Krakow 1895), p. 31. 
The text of another sermon, one authored by the eminent Cracovian theologian and orator Stanisław of Skarbimierz, complements in a way the image of the allegedly superstitious Christian: he participated in a religious worship and fulfilled his obligations in this regard. Under the influence of Church instruction, he knew how to call for divine assistance in times of need, was familiar with the words to be used to pay tribute to God, and was familiar with Christian formulas and gestures, all of which he was able to connect to the magical practices that were known to him, and that were associated with concerns about how to get ahead in everyday life.

A person convinced of the power of Christian sanctity tried to make use of it for his or her own, mundane ends. He or she believed that that power manifested itself in the rituals observed in church, it infected objects used in church, and it was contained in the texts and gestures of the liturgy. A deeply traditional faith in the effectiveness of magical practices, a belief that a person could gain favour with (or avert the anger of) supernatural forces, was brought together with liturgical rituals and their associated objects. The faithful attributed particular power to objects consecrated in a church, or to those whose contact with liturgical rituals exuded such virtues. In the second half of the fifteenth century, Tomás Štítný of Štítného, a Bohemian author of religious works designed for laymen, was aware of improper practices being performed around consecrated objects on days of the liturgical calendar intended to "comfort people" and to provide an opportunity to "praise God." He reminded his readers that these consecrated objects included:

holy water, candles (lighted at deathbeds), ashes, Easter palms, a fire sanctified on Holy Saturday, Easter candles, crumpets [placki], eggs, lambs, and, in the old days, even more objects. But given that people no longer made out of this some kind of superstition, charm or magic [the enlightened nobleman continued], they no longer bless everywhere what used to be blessed: seeds, flowers on the feast of the Mother Mary, myrtle on Saint John's Eve, and radishes on the first Wednesday of fasting. ${ }^{89}$

Tomáš Štítný of Štítného was mistaken in his belief that the "superstitious" practices he mentioned were a thing of the past, but he fully understood the phenomenon by which popular magic practices were being "Christianised" in everyday life, above all among those in the countryside, including members of the petty nobility. Sources from various countries in Central and Eastern Europe provide us with a great deal of detailed information, most of which seems to be

89 Tomas ze Stitneho, Knižky šestery o obecných věcech křestanských, ed. K. J. Erben (Prague 1852), p. 307. 
believable and is based on local realities. In addition, many of the magic practices cited there had a broad range. Indeed, the residents of a small Hungarian town who attempted to cure a person gone mad by placing blessed herbs on his body, had drawn this remedy from the universal supply of popular knowledge.

Age-old practices designed to ensure the fertility of the soil were tied to the infusion into that soil of powers contained in objects consecrated in a liturgical ceremony. Thus, ashes blessed in a church were sprinkled on the soil, and Easter palms or wooden pegs, singed in fire and blessed on the day before Easter, were planted in the ground. Fishermen and hunters, in their desire to ensure success, imbued their nets with sacral powers by covering them with smoke from burnt objects that had previously been blessed by a priest. To ensure one's health, one might cover oneself in the smoke of burnt Easter palms and blessed herbs.

Holy water, with which people often had contact in churches, and to which they had easy access, was an object that was universally used in practices tied to mass devotion, but, contrary to the Church's orders, it was often used in "Christianised" magic practices. Tomáš Štítný of Štítného, who was well acquainted with the realities of life in Bohemia's rural parishes, approached the matter of the faithful's activities in this area with understanding and did not detect "superstition". He wrote:

Thus, it is a good thing that, on every Sunday before he makes his way to Church, he sprinkles himself and his home with water, in the name of the Father, the Son, and the Holy Spirit. [...] At the same time, I do not encourage anyone to drink that holy water, nor to bathe in it. [...] It is also useful to sprinkle that water on cattle, fields and the farmstead..$^{90}$

He also discussed activities prohibited by the Church or viewed with mistrust by theologians, who were sensitive about laymen usurping those powers to bless and sanctify that remained in the hands of priests, although perhaps he did not know of the activities against which Nicholas Magni (from Silesia, author of a treatise on superstition dated 1405) warned simple village residents, who were giving their animals holy water to drink to protect them from being attacked by wolves. This learned theologian harshly condemned the attribution of consecrated objects with exaggerated powers, in any case with powers that were incompatible with those given by the Church. ${ }^{91}$ According to Nicholas Magni,

90 Ibid., p. 308.

91 K. Bracha, Teolog, diabeł i zabobony. Świadectwo traktatu Mikołaja Magni z Jawora, "De superstitionibus" (1405 r.) (Warsaw 1999), Chapter 3. 
holy water, wax from paschal candles, Easter palms, consecrated herbs, and holy oils were not to be used for mundane purposes, including the health of people and animals, harvests from fields and orchards, and protection against storms and hail.

Among the so-called res consecratae used in popular magic practices, a significant role was played by candles consecrated in churches on the Feast of the Purification of the Blessed Virgin Mary. In Poland, they were known as gromnice, and hromnice in Czech, because, according to common knowledge, such candles lit during a storm were to protect users and their property from being struck by a thunderbolt (grom in Polish, hrom in Czech), which provides yet another set of circumstances confirming the significance of the fear of fire, which could destroy wooden homes and the harvest stored in barns. In principle, the Church did not oppose this use of consecrated candles, but through words spoken by priests and written by authors of religious works, it disapproved of their use in magic practices of other kinds, including those that were curative and preventative in nature. Thus, we learn of the use of wax from sanctified candles for tooth pain, and the branding of cattle with the sign of the cross in order to prevent various diseases. Utraquist priests, who were always harsher than their Catholic counterparts when it came to popular religiousness, criticised and mocked the belief that associated consecrated candles with any particular power, particularly the power of defence against lightning. One preacher from the Bohemian Utraquist Church shamed his flock by stating that lightning had also occasionally struck church buildings, despite the fact that there was no shortage there of consecrated candles. By way of summary, he added: “They are merely superstitions."

\section{Magical Words and Texts}

Christian content was entangled with traditional content in magical formulas that were expressed on a daily basis, and that focused on various needs. In my earlier discussion of the texts of prayers, I passed over one of its functions, one that was quite different from those foreseen in Church instruction. The fact is that prayers, as taught by the Church, were incorporated into a rather complicated context of magical formulas that nonetheless maintained their archaic layer. Having said that, other formulas referred entirely to that which was contained in Christian liturgy. The texts of Bohemian incantations, found in sixteenthcentury records, represented an integral part of commonly known prayers. He who was under threat of attack had to promptly declare: "I see my Saviour, so I fear no enemy, visible or invisible," and then say three Lord's Prayers, at which 
point the danger would pass. ${ }^{92}$ Worries and troubles could be staved off by kneeling down with one's face toward the sun and saying five Lord's Prayers, five Hail Marys (in homage to Christ's five wounds) and one Apostles' Creed, after which the supplicant had to utter the words of a suitable formula. Incantations and other formulas, about which we know very little, accompanied the collection of medicinal herbs; in the West, the Church opposed these practices as early as the Early Middle Ages, and tried to replace them with the Lord's Prayer and the Nicene Creed. In the fifteenth century, one theologian associated with the University of Krakow expressed hope that those who collected herbs would toss aside old, traditional songs and superstitious words, and would take up instead devotional Christian prayers. In that same century in Bohemia, there was a wellknown magical text that was useful in the search for medicinal roots. The Lord God, roaming the earth (we will return later to this theme of Jesus on earth), talks to the people, including three "happy" brothers: "Where are you going, you three happy brothers? Lord, we are going to dig up various roots, for various wounds." Based on these examples, we might well argue that storylines that included Christian themes, the name of God, indeed entire prayers, were enunciated in order to enhance the power of ancient incantations. Having said that, there can be no doubt that those who, in solitude, uttered the words of Christian prayers together with incantations and conjurations did so believing not only that their goal was mundane, but also that they were exhibiting their devotion. In statements designed to stave off trouble, it was potentially enough to simply utter a holy name or a phrase from a Christian blessing. From Wielkopolska, we know of a magical formula designed to ward off storms and hail, which represented the most basic threats against the key requirements of human existence: "Storm, you rise up through God's power, the Virgin Mary's power, with the support of all the saints, through God's will. The Virgin Mary, Saint Mary Magdalene, Saint Ann and the Son of God himself, all of them order that you move into the empty forest, the empty mountains, an empty space, so that no one will be harmed." ${ }^{93}$ In this form and variations on it, we can also find, alongside the obvious Christian element, an element that is deeply archaic, one that is associated with the conviction that evil needed to be expelled "outside," beyond the human household, the farmstead, the settlement; in a nutshell, beyond the world that was close to the human being. In old Polish, the word "empty" referred to, among other

92 Č. Zíbrt, “Staročeská zaříkadla a lekovadla nemocí,” Český lid 14 (1905): p. 10.

93 J. Woronczak, "Procesy o czary przed poznańskim sądem miejskim w XVI w.," Literatura Ludowa, No. 3 (1972), p. 51. 
things, areas not inhabited by people. The wilderness and forests were inhabited by various demonic beings with a pre-Christian lineage that posed a threat to human existence; other such beings preferred spaces in the hills or mountains. Evil and danger, which, in traditional culture, were treated in an animistic way, had to be pushed toward areas occupied by evil powers. We might add that, in other texts intended to stave off danger, including, in a similar fashion, those that were "Christianised", threats and illnesses were driven "into the lake, into the mud," thus towards another environment of popular demonology, one that in Slavic folklore was dangerous for a human being because it was full of drowned people and various other demonic creatures lying in wait. Christian sanctity, summoned by an individual for assistance in his or her battle with the forces of nature, was brought "down," towards the traditional way of thinking about, and understanding, the world.

Some texts associated with folk attempts to ward off danger contain traces of ancient myths that are today no doubt poorly understood. In the fourteenth century, Tomáš Štítný of Štítného mocked such formulas: "an old woman mutters something, then cries out, then goes on about how God walked along a golden bridge and met Saint Peter, or the Mother Mary, or some other worthy figure." The idea of the golden bridge, idly invoked by this village woman-herbalist, might well have a worthy lineage tied to Indo-European mythology (it is also known in other mythological systems). However, what is most essential to us is the syncretism of faith and imagination, which is always present in folk religiousness, and is splendidly apparent in the sources under discussion here.

The written word, used in magic practices in the form of individual expressions or usually brief texts with Christian content, emerged in folk culture on Bohemian and Polish lands significantly later than in the countries of Western Europe. In fact, it was no earlier than the Late Middle Ages that the use of written texts for the purposes of non-literate people began to spread. We can tie this phenomenon in with, among other things, the growth in the number of individuals who were familiar with the art of writing and who were, at the same time, potential providers of written texts of this particular kind. There was also talk at the time about the growth in the number of parish priests, including in the countryside, in pre-Hussite Bohemia and Poland in the fourteenth and fifteenth centuries. The generally low level of education of members of the lower clergy in rural and small-town parishes no doubt encouraged the production of such texts, transcribed from the basic liturgical books. These priests surpassed (more or less) the simple faithful in terms of their skills in Latin and their knowledge of reading and writing, but it was often the case that they distinguished themselves 
very little in terms of their mental and intellectual horizons. Parish residents had contact with the loose clergy; that is, the clerici vagabondae, who wandered the countryside in search of a way to make a living, and who could serve the nonliterate population by applying their reading and writing skills in exchange for some kind of remuneration. We also cannot forget the sextons, sacristans and organists who had acquired certain writing skills in parochial schools. We meet such people quite commonly in documents describing cases involving magic and charms as they moved through Church courts.

Let us begin with expressions and texts recorded on pages, plaques and other objects that eventually replaced traditional amulets (no doubt such objects and amulets coexisted for a certain time). Polish and Bohemian Christians at the end of the Middle Ages had long before given up wearing around their necks the fangs and claws of wild animals, as their Slavic ancestors had done to scare off evil powers. But some in the fifteenth century still wore around the neck, for apotropaic reasons, certain roots and stems selected from medicinal plants. These amulets were known in Polish as nawięzy, and in Czech as návazy. A questionnaire put together around the middle of the fourteenth century for Bishop visitations in one of the Polish dioceses contains a question that asks whether or not there were women in the parish practicing witchcraft, whether they were digging up plant roots and making necklaces, "that is, in the local vernacular, nawięzy." ${ }^{\prime 4}$ We also come across nawięzy both as some kind of obscure objects used in the practice of charms and spells, and in the sense of texts written with magical goals in mind, long known in the West as caracteres. One Polish author of sermons from the fifteenth century tied this folk name for amulets with recorded texts based on fragments from the Gospel and the lives of holy martyrs. Written Christian texts joined forces with traditional folk practices, as if unnoticed.

Proscriptions formulated by theologians and preachers against the indecent use of written texts, placed at the disposal of the non-literate faithful, focused above all on those texts that were believed to have medicinal effects. Based on sermons by the Bohemian reformer and moralist from the second half of the fourteenth century, Jan Milíč of Kroměříze, who rebuked clerics more than anyone else who drew up caracteres for simple people, we become familiar with the practice of writing down evangelical verses on communion wafers, laurel leaves,

94 S. Librowski, "Wizytacje diecezji włocławskiej," Archiwa, Biblioteki i Muzea Kościelne 7 (1964), p. 170. Regarding Bohemia, see F. Šmahel, "Stärker als der Glaube. Magie, Aberglaube und Zauber in der Epoche des Hussitismus,” p. 324. 
sheets of paper, lead plates, and apple skins, which were supposed to be effective particularly against fever, toothache and eye pain, and headaches. ${ }^{95}$ The superstitious activity that drew the harshest criticism of these theologians involved these two verses: Jhesus autem transiens (Luke 4:30) and Lutum fecit Dominus ex sputo (John 9:6), transcribed during the reading of the Gospel. Verses were chosen that had content associated with the goal for which they were to be exploited. Thus the words of the Gospel of Saint John could prevent eye pain: "[...] and he [the Lord] anointed the eyes of the blind man with the clay."

In sermons written particularly by Polish authors and generally reprimanding people for using "certain words" in their written texts, we find various references that might have involved the creation and use of amulets bearing the names of the Three Wise Men. Significantly earlier, people in German lands had attributed magical protective powers to such texts. The same applies to the names of the Wise Men both when fully written, and in the form of their initials $\mathrm{C}+\mathrm{M}+\mathrm{B}$, worn by people as amulets protecting them against, among other things, epilepsy. These and related practices did not involve only the inhabitants of Polish and Bohemian lands; on the contrary, written texts tied to superstition had a significantly broader range. But what is essential here is the fact that they grew in the soil of local and age-old concepts and beliefs. Measures that were preventative, protective and curative in nature bent to the will of the times, which conditioned a successful outcome; Christianisation yielded to the determinant of time: Lent, the best weeks to collect medicinal herbs, and time spent reading the Gospel, during which short verses were transcribed so they could later play the role of an amulet, replaced natural time as the point of reference at work in traditional folk culture.

Written texts endowed with preventative and curative powers also ended up in the rural environment, in which concern for the health of domestic animals was certainly no less than for the health of family members. Miraculous scraps of paper containing words that could heal both people and animals were thus highly valued. People knew to place them on the bodies of a sick person or sick ox, at which time they no doubt uttered the appropriate words. A simple healing method involved placing a piece of paper in the animal's mouth with "holy" words written on it. One possible medication was the name of Saint Luke.

95 Johannis Milicii der Cremsir Tres sermones synodales, eds. V. Herold, M. Mráz (Prague 1974), pp. 68-69. 


\section{Divination}

I want once again to raise the issue of divination practices, which the Bohemian preacher Johlín of Vodňan associated above all with city life, but which also existed in various forms in cities, towns and villages. Johlín, who like other moralists of his day was convinced that cities were more sinful and criminal than villages, asked: "Where on earth are there more soothsayers than in Prague? Old women foretell some of the strangest things, and many people believe them. And telling such huge lies brings them piles of money." ${ }^{96}$ But this urban divination differed from the kind of future-telling that had been going on in villages since ancient times. Not only did urban divination revolve around a somewhat different set of vital issues, but it also involved different divination techniques, which were often of foreign origin. In fact, cities were associated with what might well be called specialised divination, which remained in the hands of individuals who enjoyed the recognition of their own clientele. When, around the middle of the fifteenth century, money went missing from the Poznan city hall, two members of the city council, in search of assistance in finding it, visited a soothsayer who lived just outside the city, a blind man who used quite peculiar techniques. In the Diocese of Poznan, an "old woman diviner" from the countryside was put before a church court accused of practicing "divination, spells, and curses against the true faith" with the use of her own special herbs and associated objects. It is probably the case that almost every village had an old woman of some kind who knew how to cure and heal using herbs, who knew the magical practices that applied to the needs of the local population, and who knew how to divine better than others. Simple knowledge of the ways to predict the future were, in any case, accessible to people who were not initiated in the complicated art of divining. One technique in this regard involved spilling wax or lead, or salt blessed on Ash Wednesday, and then predicting from the result who among those participating in the practice would die sooner than others. Tomáš Štítný of Štítného always attributed similar knowledge, along with a familiarity with non-specialised "homespun" magic, to women, and he thus warned the women of every home to give up any such practices that would be unwelcomed by God. These practices were also closely connected with everyday life and, despite preachers' admonishments, coexisted easily with religious practices. After all, both Church authorities and lay officials did not apply serious repressive measures against the guilty parties; they generally satisfied themselves with a promise that the banned practice

96 Řičan, Johlín z Vodňan, Křižovník kláštera zderazského, p. 68. 
would be avoided in the future. In this context, it is important to point out that Church leaders drew a distinction between such individuals and people accused of practicing certified magic, especially if it harmed someone else's health or property, although even in these cases we rarely come across cases that resulted in a judge's harsh punishment. Both in Poland and in Bohemia, at least until the end of the Middle Ages, the myth of witches acting on behalf of the devil, and out of hatred towards God, remained absent.

Let us return to the above-cited "confession" by the superstitious Christian who understandably drew no distinction between that which belonged to the field of religion and that which was closer to the world of magic. In his eyes, in cases where traditional practices in search of health and prosperity were carried out using Christian terms and gestures, no such distinction existed. This person represented a kind of religiousness that was widespread at the time, one which turned towards the temporal, which was impatient, and which demanded immediate gifts directly from God.

People participating in religious worship attempted to tailor that worship to ongoing temporal needs on the basis of tradition and their own experience. In so doing, they did not forget about their obligation, and their need, to honour God and the saints. In addition, some individuals took their own initiatives, in light of their feeling that certain practices sanctioned by the Church were insufficient. Such an attitude was shared, for example, by those who did not bathe on Thursday as a way of paying homage to Christ, who had been captured on that day in Gethsemane, and by those who did not consume the heads of animals on days dedicated to the Christian martyrs who had been beheaded by the pagans. The Church reproved these practices, just as they did various other activities that ran against Church tradition. But it treated them as relatively insignificant, marginal elements in the layman's religious life. However, let us return to the phenomenon of the Christianisation of traditional culture, beyond the Church, by considering evidence provided by theologians in the fourteenth and fifteenth centuries who spoke bitterly about Christians who would kneel down in front of a new moon, or take off their cap and mumble something into it. We do not know to what lands Nicholas Magni and Stanisław of Skarbimierz were referring when they recorded this information, which is common in several versions based on ancient sources. But we do know that we are not yet on the trail of traditional Slavic culture, in which the moon cult was absent. However, we approach that culture when we mention that those residents of Poland who greeted the rising sun, which had a powerful presence in ancient Slavic beliefs, did so by baring their head and uttering a prayer, which perhaps had Christian content, but which perhaps was simply offered to the sun. 



\section{Christianity under the Influence of Folklore}

Historians who define the focus of their research as the Christianisation of folklore and the folklorisation of Christianity most often argue that the distinction between these two phenomena is not as obvious as it might seem at first glance. Efforts to strictly differentiate them often transpire to be formal attempts that do little, if anything, to explain the reality of popular religion. These two phenomena are entangled in more ways than one, and what determines the extent to which they are distinct is more a matter of optics than the eloquence of the source material. The superstitious people who Nicholas Magni knew (no doubt residents of German lands, Silesia, or Bohemia), who placed offerings at the foot of the cross on Good Friday, were no doubt "folklorising" religion through the deeply archaic act-one which was not in accordance with Church customs-of offering a gift. But were they not also simultaneously "Christianising", in a sense, traditional culture by renouncing ancient sacrificial rites in favour of spontaneous homage paid to the symbol of Christ's Passion? We can ask similar questions regarding the annual practice of peasants in a Wielkopolska village who, on the anniversary of the death of Bogumilus, brought eggs and cheese to the old oak that was thought to be where he died. In my continued discussion of the points where Christianity and traditional beliefs and attitudes overlapped, I will thus not emphasise the extent to which any particular phenomenon belongs to one or the other category.

The terminology used in certain church holidays, particularly in those associated with the cult of the Most Blessed Virgin Mary, seems here to be significantly meaningful. In Poland and Bohemia, four Marian holidays retained names, alongside their church, liturgical names, which had folk origins, and which referred to rites carried out on that day. Thus, the Feast of the Purification of the Blessed Virgin Mary was also named, in Polish, Święto Matki Bożej Gromnicznej (Feast of Our Lady of Thunder candles), associated with the blessing on this day of candles that provided protection against thunder and lightning; the Visitation of the Blessed Virgin Mary had the name Święto Matki Bożej Jagodnej (literally: the Feast of Our Lady of the Berry), associated with the collection of berries; the Feast of the Assumption of Mary was the Święto Matki Boskiej Zielnej (literally: the Feast of Our Lady the Herbaceous; in Bohemia, approximately: Our Lady of the Root); and the Feast of the Nativity of Mary was also called Święto Matki Boskiej Siewnej (approximately: the Feast of Our Lady of Sowing, or the Seed). These names were tied to the Church's blessing on these days of fruits, 
medicinal herbs and roots, and sowed grains, and these rituals were intended to replace old magical practices surrounding nature's produce. We might add that we find some of these names in Late Middle Age syllabic verse calendars (cisiojanae) used in rural parochial schools as a tool in teaching basic knowledge of the liturgical calendar. These texts are of great interest, for they are situated on the border between Church culture and the culture of the agrarian world.

We can also observe the influence of tradition beliefs in those Christian rituals that attracted the participation of large groups of the faithful. In this regard, let us very briefly turn our attention to the Corpus Christi celebrations, a holiday that exhibited a very powerful Eucharistic devotion at various levels, including through the procession, which brought together crowds of the faithful but which also allowed space for certain elements of folk culture. Among the latter was the belief in the magical role of this procession as manifested, for example, in the custom of snapping off twigs from the altar, decorated in greenery, and taking them home. The tradition of including flower-covered wreaths in the procession no doubt had its roots in ancient folk rituals, in which wreaths made of suitable plants were often an essential element of certain holidays (we should note, however, that the use of wreaths decorated with roses in Corpus Christi processions also emerged in Western Europe). Pastors in the Utraquist Church did not look kindly upon such wreaths. Jan of Rokycany was irritated by this custom, which he regarded as a manifestation of superficial piety, one that was particularly improper on the day of a holiday with significant Eucharistic content.

\section{The Natural Environment: Older and Newer Beliefs}

Let us devote some attention to the ways in which archaic beliefs associated with the natural environment and its venerated objects are entangled with Christian beliefs. In the centuries under discussion, the former had already largely faded from collective memory, and to the extent that they remained, they did so in the form of a feeling that certain elements in the natural environment were singular, or as a belief in the good or evil powers associated with them. These beliefs clearly involved the three basic elements of the micro-cosmos shared by various traditional worldviews: namely water, trees, and stones. Water, which in its most basic sense is cleansing and curative, could also represent an unclean and dangerous environment, where evil powers dwelled and where demonic beings and the souls of the drowned resided. At the beginning, people in various Church groups attempted to cleanse water of impure powers, regardless of the names that were given to those powers. According to the well-known chronicler 
Thietmar of Merseburg, Reinbern Bishop of Kolberg (as of 1000 AD) acted in this manner by throwing "four stones covered with oil and sprinkled with holy water," into the Baltic Sea. ${ }^{97}$ Significantly later, a Polish chronicler, in his entry for the year 1278, wrote about the devil who inhabited a lake or pond in the Diocese of Krakow, and who harassed fishermen in their work. One solemn procession of monks, knights and people holding crosses and church banners to the edge of the water, the goal being to capture and neutralise evil powers, brought a result that frightened participants. After several futile attempts at casting a net into the water, a terrible monster was finally pulled out, which had the head of a goat with red, glowing eyes, and which-with a howl-lurched around in the water. Abandoning their crosses and banners at the edge of the lake, the participants fled the scene in panic, so frightened that many of them became seriously ill. ${ }^{98}$ We can regard this story, which no doubt circulated among the people living throughout the Cracovian lands, as evidence of the confrontation of two layers of belief, and it is not difficult to determine the direction of influence here. The plot of the story seems to talk about the "Christianisation of folklore"; a procession exhibiting its Christian character makes an attempt to obliterate not just a diabolic power, but also unknown powers that belong to the world of folk beliefs. This argument is weakened by the character of the above-described ritual, which resembles more a kind of folk ritual of purification than a liturgical exorcism. In any case, it represents an ambiguous didactical defeat.

In the sources, we come across more convincing examples, in later centuries, of the Christian sacralisation of waters, particularly those that had survived in memory as foci for pagan cults. With encouragement from the local clergy, these waters became holy springs, wells and ponds that maintained their own positions in folk religiousness, spontaneously and not always fully approved by the Church. The Polish chronicler Jan Długosz cited the legend of Saint Stanisław's finger, which was thrown into a pond in Krakow by henchmen under orders from King Bolesław II the Bold to chop the body of the bishop-martyr into pieces. This exceptional relic, swallowed from the water by a fish which immediately began to shine like a bright light, turned the pond into something

97 “Die Chronik des Bischofs Thietmar von Merseburg und ihre Korveier Überarbeitung," in ed. R. Holtzmann, Monumenta Germaniae historica. Scriptores, vol. 9 (Berlin 1935), ks. 7, cap. 72; Polish translation: "Kronika Thietmara," trans. M. Z. Jedlicki (Krakow 2002), p. 213.

98 Rocznik Traski, ed. A. Bielowski, in Monumenta Poloniae historica, vol. 2 (Lvov 1872), p. 844. 
miraculous and curative. ${ }^{99}$ Contact with that which is sacred in Christianity thus gave rise to a "new" cult of water containers, springs and wells-is it the case that their pagan past was entirely forgotten?

Christian content was conferred upon trees, which, according to ancient beliefs, were associated with certain powers that could either assist an individual (curative) or prove dangerous. It is appropriate to cite the example of a somewhat obscure cult of an extraordinary pine tree growing in Bohemia that was banned by the Archbishop of Prague, and whose members were threatened with excommunication (1403). ${ }^{100}$ Beyond the laconic-sounding ban and a brief mention in one treatise by Jan Hus, we know very little about this cult. Opinions rejecting the non-Christian source of this worship of a miraculous tree would seem to be justified; after all, pine trees did not have magical powers in traditional folk beliefs. The hypothesis has been put forth that there were religious undertones: perhaps news that a kind of holy object had been found there, perhaps its branches were arranged in the sign of the cross, etc. Comments by John Hus confirm this suggestion; according to him, it was only the Archbishop's ban that prevented priests from continuing to bless the tree, which the people and monks had been demanding.

And finally, stones, which in Slavic folklore occupied an important place until our century. Huge boulders struck people with wonder through their unusual character, their durability, and their supposed hidden powers. They became an object of faith, and a place for rituals, particularly when they exhibited certain features: natural impressions and recesses, or shapes that fired the imagination. Folk legends recorded in the last two centuries, in and beyond Poland, attest to the many so-called boże stopki; that is, symbols cut into large stones around which grew various stories with religious content, for example that the Mother Mary once stopped there to rest with the Baby Jesus. The Christianisation of ancient beliefs is confirmed in sources from the Late Middle Ages; for example, in one document from Pomerania from the middle of the fourteenth century, which discusses where to find land for a Cistercian monastery, the area around a "rock called Bożystopka" is mentioned. ${ }^{101}$ It happens to be a fact that worship of

99 Joanni Dlugossi Vita sanctissimi Stanislai cracoviensis episcopi, ed. A. Przeździecki, in Joanni Dlugossi Opera omnia, vol. 1 (Krakow 1887), 73 ff.; A. Witkowska, Kulty pątnicze piętnastowiecznego Krakowa, pp. 83-84, 221.

100 J. Kadlec, "Synods of Prague and their Statutes (1396-1414)," Appolinaris 64 (1991): p. 246; Z. Hledíková, “Jěstě k počátkům blanické pověsti," Sbornik vlastivědných prací z Podblanicka 20 (1979), pp. 121-140.

101 Pommerlisches Urkundenbuch, ed. M. Perlbach (Danzig 1882), p. 283; J. Banaszkiewicz, "Fabularyzacja przestrzeni," Kwartalnik Historyczny 86, No. 4 (1979), p. 988. 
the "Christianised" stones was worryingly widespread. At that time, such worship could provoke resistance on the part of Church leaders, which is precisely what pilgrims in Bohemia confronted in 1466, when they were on their way to the feet of Saint Wolfgang imprinted on a stone in Kájov. An administrator of the Bohemian Catholic Church, Hilarius of Litomerrice (d. 1468), who was familiar with the size and shape of these impressions, remarked without irony that if Saint Wolfgang had really left them behind, his two feet must have been of different sizes and shapes. In any case, neither prohibition nor ridicule stopped the folk cult, which was still noted at the beginning of the sixteenth century. Of course, cults of this kind had to be brought into being and cultivated. Apparently, residents of a certain village in Kujawy themselves carved the outlines of the "feet of Saint Florian" - the local church had taken up the call of that saint-in order to be able to kiss them and to bring food.

Occasionally, there is no way to establish if Christian content, as an external layer of an old cult, in fact neutralised ancient beliefs, or if these beliefs also continued to function alongside Christian worship. A large stone, whose history is associated with the founding of the Bernardine monastery in Skępe in western Mazovia, was the object of certain ancient beliefs before it became a place where the Mother Mary appeared, and where she left behind an impression of her feet. Eventually, contrary to the monks' expectations, the immense stone began to attract its own worshippers instead of becoming part of the Marian cult. These were no doubt the very same pilgrims who were coming to visit the church and the monastery. The monks then tried once again to Christianise the boulder by setting it into a wall of the church; or perhaps, as another source claimed, they hid the boulder by covering it with soil "so that simple people did not believe there was something numinous about it" (in eo aliquid esse numinosus). ${ }^{102}$ Such a measure would be evidence of fears in the monastery that the boulder was becoming an undesired rival to the Marian cult. However, once again we must note the tendentious wording of Church sources, which were trenchant in their juxtaposition of "pure" religious worship with beliefs that were, if not pagan, at least suspicious. It does not appear that pilgrims travelling to visit curative waters approved by the Church were very different, in terms of intellect or religious imagination, from those who visited the impressions of sacred feet or an unusual stone, from which they could chip off a piece to bring home. Here, too, Christian

102 M. Maciszewska, "Skępe. Początki klasztoru bernardyńskiego i ośrodka kultu maryjnego," in Peregrinationes. Pielgrzymki w kulturze dawnej Europy, eds. H. Manikowska, H. Zaremska (Warsaw 1995), pp. 305-306. 
beliefs and traditional beliefs were tied together to make up a larger whole that the Church was not able to disturb through instruction and prohibition. The Church's approach to this matter was flexible, if not simply indecisive.

\section{The Folklorisation of the Saints: Evidence from Syllabic Verse Calendars}

The worship of saints, which was subject to relatively little scrutiny from the Church, certainly much less than the worship of God the Father and Christ, easily succumbed to external influences and to non-Christian ideas and beliefs preserved among the faithful. There was already talk of direct and, so to speak, familiar ways of relating to the saints, which easily went hand in hand with worship and faith in their powers of mediation, but also with their autonomous strength. It is not difficult to detect here archaic elements that are clearly distinct from exemplary Christian attitudes. Aleksandra Witkowska has argued that the punishments we read about in sources (those that were meted out to people who did not keep the promises they had made to the saints) hark back to a belief, known to primal religions, in the vengeance of angry and offended gods, who withdraw their favour from an individual and thus become his persecutors. ${ }^{103}$ The widespread practice of placing gifts at saints' graves, or at places where their relics or miraculous likenesses were located, was doubtlessly magical in nature; gifts that were identified with the donor or which resembled (in appearance) the object associated with the request for miraculous intervention. The goal here was to employ the saint's powers, which were most effective when activated in the appropriate locations, in the protection of a person, his healed body part, etc.

We also come across actions by which grateful saints would assure people of continuous material success. Matthew of Janow, the pre-Hussite Bohemian theologian mentioned above, knew of the annual practice of "bestowing" valuable objects on statues of holy people, statues that were most closely identified with the deceased prototype dwelling in heaven. Many people believed in the effectiveness of such gifts, which, due to the reciprocal nature of relationships with saints, ensured a household's prosperity. In any case, these holy figures were not very demanding: from people who were not rich, who could not afford to offer, for example, a valuable belt, they had to be satisfied with a gift in the form of silk, or a linen shirt. ${ }^{104}$

103 A. Witkowska, op. cit., p. 215.

104 Matthiae de Janov dicti Magister Parisiensis Regulae Veteris et Novi Testamenti, vol. 3, ed. O. Odložilik (Prague 1926), p. 204. 
The Church did not take a unified stance towards these attitudes and activities. Zealous and learned individuals, advocates of programs for the internal renewal of the people of God, such as Matthew of Janow, did not spare "idolists" their harsh criticism and admonishment. However, many levels of holy men, beginning with parish priests, were somewhat indifferent towards these practicesthey did not delve deeply into their magical or half-magical motifs. Indeed, priests and monks recording evidence of miracles accepted in good faith stories about saints avenging themselves for having been offended, and conferred upon such stories an instructional significance.

Generally speaking, those in Church circles agreed that that the plane of religiousness on which the faithful met the saints had to be "lowered." In part, they inspired the convergence of the secular with the sacred, and thus concepts that belonged to traditional folk culture merged with religious worship of the saints. The clearest evidence of this phenomenon comes from the cisiojanae mentioned above, syllabic verse calendars put together in the thirteenth and fourteenth centuries (and later) in the national languages. It is appropriate that we devote some attention to these calendars. Earlier, I mentioned that these texts, which were simple in tone and easy to remember, were used in the instruction of the basics of the Church's annual events in rural parochial schools. Their didactical purpose amounted to instruction in the order and dates of liturgical holidays: days devoted to glory of Christ, Mary or the saints, in turn, during the entire church year. Beyond mentioning the saints worshipped throughout the entire Church and those whose worship had a narrower range (using Bohemian and Polish intonations, often in the diminutive and in forms used by the local population), cisiojanae convey, in very small doses, the basic elements of religious knowledge. They describe the miraculous events in the saints' lives, their services to the Church, and their martyrdom. In Polish syllabic calendars from the fifteenth century, we thus read for particular dates: "God converts Paul" and "Saint Mary taken into heaven," and in the Bohemian cisiojanae, we read: "Martin gave Jesus a half-cloak," "Nicholas resurrected three children," and "Thomas touches the wounds of Jesus," etc. Beyond these, the church authors of syllabic calendars depicted-in a way that might appear to us primitive and awkward-saints carrying out tasks associated with rural folk and corresponding to a given season of the year, or a more specific date. Thus, in the Polish calendar for the appropriate dates we read: "Gregory planting cabbage," "the great Saint John sharpening a scythe and sickle," and "Peter carries a sheaf of wheat, Dominic carries hay, Lawrence builds a haystack." And in the Bohemian calendar: "Gertrude and Benedict are ploughing," "Helene is sowing millet, Urban is happily tearing the bast," "Remigius is going with Francis to plough." The saints participated in 
what was important to farmers, namely nature's harvest: "Mark gave us grass," "[?] found grain in the rye," and "Erasmus and Boniface went to pick berries in the summertime." ${ }^{105}$ Along with the rural folk, the saints felt the burdens that nature imposed on the people: summer heat waves, autumn cold, winter frosts. Like normal people, they looked for a way to cool down in the river, and they warmed themselves at the fire. In the cisiojanae, everyday life, work in the field, the farmer's repose, and the signs and realities of nature all coexist with the sacred.

In the texts of these verse calendars we find scraps (more or less) of ancient, pre-Christian beliefs and myths. While some of them are hidden under the surface of Christian content, others clearly reveal their archaic nature. First of all, we see them in the folk names, tied to pre-Christian traditions, given to Church holidays. The name Szczodry Wieczór mentioned above was used in the fifteenth century to identify Christmas Eve, and other folk names discussed earlier were associated with holidays tied to the Mother Mary.

Somewhat surprisingly, and with probable justification for that surprise, we can see traces of archaic Slavic culture in texts used as instruments in the Christianisation of the countryside in the Late Middle Ages. A Bohemian cisiojanus from the second half of the thirteenth century contains the motif of snakes coming alive in spring. If we look back at ancient beliefs, we recognise in these snakes the souls of the dead which, after the season of winter slumber, became active again in the spring and stimulate the cultivation of nature. A Polish cisiojanus from 1471 indicates the approximate date of the Slavic autumn day of the dead; we find between Saint Francis' feast day and Saint Hedwig's feast day; that is, between 4 and 15 October, the entry: "the peasant prepares the wake," which revolves around food and drink prepared for the dead arriving on earth, or for the dead to be honoured by the living.

In the syllabic calendars, Christian saints coexist with old traditions, although they raised bad associations among rigorous theologians and priests. On Saint John's Eve; that is, Kupala Night, ritual bathing took place, which as we recall had a cleansing character. In cisiojanae, traces of the old fears of "evil" and threatening days, or longer periods of time, crept between the names of the saints with

105 The above-quoted texts are in: "Średniowieczny polski cyzjojan płocki", Archiwum Literackie (23); Miscellanea staropolskie, ed. T. Ulewicz (Wrocław 1980), pp. 7-21; J. Fijałek, “Cizjojan polski z 1471 r.”, Prace Filologiczne 12 (1927), pp. 428-448; K. Doskocil, “Vývoj cisiojanů u nás," Sbormík historicky 6 (1959), pp. 112, 113, 121, 138, 139, 150, and 151; J. Nováková, České cisiojány od 14. století (Prague 1971). 
their peculiar Polish and Bohemian sounds. According to traditional belief, it was on these days that evil powers emerged with intensified activity; thus, on the day of the feast of Saint Lucy, 13 December, which was regarded in folk tradition as the shortest day of the year, a Polish cisiojanus exhorted the faithful: "on Lucy, stay at home."

The presence of traces of traditional, rural culture in texts associated with Christian didactics appear to stem from inspiration provided by the clergy, who viewed this approach as one that encouraged the adoption of Christian content in the rural environment. At the same time, syllabic calendars reflect a certain state of religious awareness in which it would be extremely difficult to isolate from one another these two intertwined systems of belief and imagination. These calendars do not distinguish between what is holy and what is worldly, and they are in general tolerant towards what the authors of theological treatises tended to conceive in the categories worthy/unworthy and allowed/prohibited.

\section{The Sacred among People}

In the Late Middle Ages, it became easier for Christian practices and rituals to penetrate traditional attitudes. Today, we speak of the "interiorisation" of religious content, about tendencies to "appropriate" that content, to make it accessible and more intelligible. Included in this kind of phenomenon were folk pilgrimages to "holy" places by simple laymen where Christian sanctity, officially certified by the Church, had not yet made an impact.

Residents of the Bohemian village who were attracted by news of that miraculous pine tree doubtlessly began shortly thereafter to make pilgrimages to other, not-too-distant places that were positioned, we can imagine, significantly higher in the popular hierarchy of saintliness. A resident of the Blaník hill region was said to have miraculously discovered the grave of the apostles Peter and Paul. Once again, our only source of information here is a declaration issued by the archbishop of Prague (1404) condemning the spontaneously generated cult, ${ }^{106}$ from which we also learn that news was being spread throughout the region that whoever visited that site and dragged a stone onto the future church grounds (someone apparently wanted to build a church there) would obtain sufficient credit equivalent to having attended several masses. The discovery of something so unimaginably sacred does not seem commensurate with the

106 Z. Hledíková, op. cit., 123 ff. 
rather modest credit promised to pilgrims, but we do not expect consistency from propagators of a folk cult; after all, who knows what in fact a fanatical resident of a village in the middle of a forest might declare and promise? What is more significant here, rather, is the fact that locals called forth their own cult with Christian overtones, a cult of great size and high ambitions, though those ambitions were perhaps not fully realised. We do not know where the myth about the discovery of the graves of the two most important apostles originated. But the fact is that it developed among the residents of a village far from civilizational influences, far from the great centres of Church power, and in a region that had long been infamous among clergymen, and outsiders in general, for harbouring soothsayers and witches. Jan Hus once mentioned a "cult of idols" (cultus ydolorum) practiced in this region, although we do not know if he was referring to the "superstitious" pilgrimages to the graves of the two apostles, which he condemned, or to another phenomenon unknown to us. In any case, we can assume that what we have here is a pilgrimage cult with Christian content that was based on some kind of traditional beliefs which are hardly recognisable today, but which were associated with the hills. After all, Blaník hill, like many other high-elevation areas, had its own mythology with many facets, not all of which had folk origins.

The folk imagination created and located-among the hills, in villages, alongside roads, in fields and along fences-characters in the form of messiahs, saviours, and miracle-workers. At the foundation of such a myth, which could have many and various sources, we can detect the legendary theme of Christ on a pilgrimage, visiting people in their homes and in the fields. This motif was perpetuated in, among other things, texts about repelling diseases, cataclysms, and unwelcome atmospheric phenomena. In Bohemia and Poland, such texts were written in the sixteenth century mainly on a wave of battles against witchcraft, or had been written much earlier but remained largely unchanged. They were the product of an agrarian imagination, and, handed down from generation to generation, they fertilised that imagination. For the members of that society, they made something real which, by other means, would have seemed unreal. Ancient holy times and historical times as told through the Gospel and the Apocrypha, approached the present day, and the Holy Land where Christ walked became a place that was close to Bohemian and Polish villagers. The reality evoked by one incantation, according to which the Lord Jesus would travel the world on his holy donkey, is still only vaguely defined, but in another formula, Christ and the universally worshipped holy men became a rural family working in the fields: "The heavenly king was born, he planted every field, and Saint John drove the cattle, and Saint Peter sowed the seeds, and Mother Mary brought the 
meal." ${ }^{107}$ The holiness worshipped in Church rituals and in the prayers of the faithful descended into the village and its everyday life.

\section{The People's Messiahs}

The reality invoked by the words of ritual formulas is for us a continuing matter, but we are also confronted with living individuals whom the people regarded as new messiahs and holy prophets with a supernatural power and mission. In the middle of the fourteenth century in Western Europe, the main catalyst for the rise of such figures, who attracted a large following, was the Black Death and the associated atmosphere of fear and repentance. In later times, individuals appeared whose mission was tied to the conversion of sinners and the liberation of the righteous, and whom we can most often associate with various prophetic currents with apocalyptic overtones, or with movements condemned by the Church as heretical.

In the fourteenth and fifteenth centuries, we can also find such characters in Central and Eastern Europe; their cults were usually not large, and the range of these cults was always local in nature. In any case, none of them ever approached the impressive size, in terms of the number of participants, of the cult of Hans Böhm (d. 1476), the "holy young man" from Niklashausen ${ }^{108}$, whose miracles attracted to this village great crowds of people not only from Franconia, but also from neighbouring German lands. Other individuals appeared sporadically on the scene, such as Janko of Wirsberg (Joannes de Oriente), who was active in Eger and who was a precursor of the messiah, a new John the Baptist called upon by God to cleanse Christianity of iniquity. Information contained in the sources allows us to discern here a connection with prophetic currents in the Franciscan order; thus, we can practically ignore the history of the cult of Janko as one that has no significance on the main purpose of our considerations here. But it is worth pausing for a moment to examine a self-proclaimed messiah who, in the first half of the fifteenth century, emerged in the Świętokrzyskie Mountain range in northern Małopolska. According to John of Komorów, a Polish chronicler who wrote about the history of Bernardine monasteries, a person whose followers named him Jesus travelled through a foothill region speaking to inhabitants,

107 Č. Zíbrt, “Staročeská zaříkadla a lekovadla nemocí,” p. 12.

108 K. Arnold, Niklashausen 1476. Quellen und Untersuchungen zur sozialreligiösen Bewegung des Hans Behem und zur Agrarstruktur eines spätmittelalterlichen Dorfes (Baden-Baden 1980) (Saecula spiritualia, p. 3). 
performing miracles, predicting the future, and teaching the people. ${ }^{109}$ John of Komorów himself paid tribute at a wooden church built especially for him at the top of hill, surrounded by his apostles and pupils, a group that did not even lack a Peter and Mary Magdalene. The person identifying himself as Christ tried to carry out, in his own way, the activities of the Saviour as described in the Gospel. He was a peasant messiah. He visited villages and small countryside towns, where he gained a reputation for supernatural acts that were, we might say, meteorological-agrarian in nature. He predicted weather, which was critical to farmers, and he no doubt prevented storms, harsh rains, and hail. $\mathrm{He}$ thus addressed the everyday fears and hopes of an agrarian society. Miraculous catches of fish, mentioned by one of the "false prophet's" worshippers, provided an obvious reference to the Gospel, but also corresponded to the imagination of the inhabitants of a region densely crisscrossed by rivers and mountain streams. According to John of Komorów, worshippers of the false messiah, who were paying homage to him as he sat at the altar of his own church, were surprised by a visit to the mountain summit by an official of the Bishop of Krakow, who came to capture and behead the scheming deceiver of the people.

The messiah of the Świętokrzyskie Mountain range, as opposed to many other characters called "false prophets" by Church authors, promised neither the end of the world, the final judgment of humanity, nor millennial triumph of the believers of a single, true and chosen idea. But his followers did not expect those things; rather, they came for a blessing, for support in their struggles with the forces of nature, and no doubt to have their illnesses cured. Additionally, perhaps out of a feeling that worship as conducted in church was inadequate, they wanted to meet close up, face to face, holy figures who, having descended from heaven, found themselves among mortals. It seems, however, that we must search for sources of inspiration nowhere else but in the parish church: in sermons that spoke vividly about the life of Christ and the apostles, or in paintings, especially mural paintings, representing scenes from the Gospel. The needs of imagination found fertile ground in folk beliefs, in which Christ's meanderings on earth were nothing unusual. I do not agree with the suggestion that characters in the form of "Jesus" from the Małopolska highlands functioned as "substitutes" for ancient, rural sorcerers and wizards of pre-Christian ancestry. Rather, they provide an example of the "Christianisation of folklore," an effective example, although one

109 Memoriale Ordinis Fratrum Minorum a fr. Joanne de Komorowo compilatum, eds. A. Lorkiewicz, X. Liske, in Monumenta Poloniae historica, vol. 5 (Lvov 1888), pp. 220-221. 
that is hardly convincing, if only because soothsayers with ancient attributes were active at this time, as they would continue to be for a long time thereafter, in the cultural reality of the village throughout the region under consideration here. Indeed, we have rather spoken of what I consider the "folklorisation of Christianity," albeit in a somewhat different sense than used previously, because what we are talking about here revolved around beliefs with Christian content that had already been assimilated into the culture of rural communities, and around the imposition of those beliefs on the thin layer of religious knowledge taught in churches. 



\section{The Living and the Dead}

\section{Fear of Death}

Fear of death has accompanied the human being always and everywhere, although it is also true that such fear has not been present to the same degree, or equally acute, in every era and under all conditions. In the era under discussion, people who knew that life would someday come to an end tried to stave off death, and, alongside scholarly and folk medicine, they relied on the words of Christian prayer, on handing oneself over to the care of God and the saints, and on the various methods known to traditional culture. With this goal in mind, people wore amulets in their own defence, uttered appropriate magical formulas, and practiced rites and rituals handed down from generation to generation; for example, the rite in which an image of a person who had died was carried beyond the settlement borders and then destroyed.

In Europe in the Late Middle Ages, fear of sudden death was an essential feature of human emotions; at any moment, death could surprise a Christian who was unprepared, who was leaving this earth with unremitted sins, who was not reconciled with his or her kinfolk. Historical scholarship has frequently pointed to the influence of mass human death on the collective psyche. The Black Death in the middle of the fourteenth century, which devastated the populations of Western Europe, caused significantly smaller losses in central and eastern parts of the continent. Most importantly, the epidemic affected only a small part of the lands under discussion here.

But contagious diseases with various ranges (sometimes wide), which returned again and again throughout the fourteenth and fifteenth centuries, were incredibly severe. Hanna Zaremska, author of a study on attitudes towards death in Poland in those centuries, has argued that:

the second half of the fifteenth century in particular was a period marked by persistent plague, although its territorial reach, duration, and toll on human life are difficult for scholars to estimate. What we know is that, around this time, entire villages disappeared from the map of the country; in some urban parishes, dozens of bodies were buried every day. [...] Długosz regarded instances during the epidemic in which people avoided contagion as miraculous. People fled densely populated areas, hiding themselves in forests; city authorities and clergymen, those who remained alive, abandoned their offices. [...] To die during the plague meant, at least in stereotypical thinking, sudden and unexpected death. ${ }^{110}$

110 H. Zaremska, “Człowiek wobec śmierci. Wyobrażenia i rytuały," in Kultura Polski średniowiecznej XIV-XV w., ed. B. Geremek (Warsaw 1997), p. 506. 
Frequent recurrences of epidemics of deadly contagious diseases also haunted Bohemian lands in the fourteenth and the first half of the fifteenth centuries. Of course, these situations created an atmosphere of danger and fear, but it also led people to become accustomed to death, to have hardened feelings towards death. The latter phenomenon was also often a consequence of wars, in which death manifested its omnipresence. The Hussite wars, which were lengthy, involved particular brutality, and which were marked by the wholesale destruction of people and property, had what undoubtedly were deep psychological and emotional consequences on Bohemian society, one of which was apathy towards matters associated with death, or at least doubt in the effectiveness of measures that had been widely practiced to ensure the soul's success after death. As the Utraquist Pavel Žídek (d. 1471) noted with bitterness: "People today laugh at this."111 But on the broader, Central and Eastern European scale, not excluding Bohemia in the post-revolutionary era, manifestations of Christian concern for salvation dominated.

Theological and literary works devoted to the art of the exemplary, Christian death provided a remedy for the threat to the human soul posed by a person's lack of (or incorrect) preparation for death. This formally diverse kind of writing, which originated in the West, also took root in Central and Eastern Europe in the fifteenth century. It had its counterpart in Gothic painting. A mural painting in the Kingdom of Hungary from 1430 in what today is the Slovakian town of Želiezovce, which is particularly instructive given its content, demonstratesthrough the presence of angels and the devil at the bed of a dying man-the drama of the moment preceding a person's death. And with God the Father, Jesus, and the Virgin Mary hovering over him, the painting shows the closeness of the judgment that awaits the individual's soul just after it has left the body.

\section{Concern over the Soul's Fate}

Above all, thoughts turned to securing the soul's fate after death. Broader knowledge of purgatory, the place where posthumous penance is performed, and which, in the words of priests, could be severe and lengthy, became an incentive for people to gain for themselves indulgences through which punishment could be shortened or even annulled. By visiting the churches, chapels and altars that enjoyed the privilege of selling indulgences, and by saying the proper prayers and carrying out the religious practices introduced by the Church, the faithful gained

111 R. Urbánek, České dějiny, vol. 3, part 2 (Prague 1930), p. 775. 
hope-measured in days and years-that their judgment after death would be relaxed. In the monasterial church of Saint Vincent in Wrocław alone, a pilgrim coming to view the relics of the Holy Cross could obtain more than 68 years of indulgence. On the appropriate day of the year, he or she could also visit two chapels in the church to obtain, after saying several prayers in a row, 30 years and 100 years of indulgence. The possibility of obtaining complete indulgence, one that washed away all sins committed by an individual until that moment, encouraged people to undertake numerous peregrinations both near and far. Ludolf von Sagan (d. 1422), a prominent critic of Church and religious life in his day, took note of the fact that: "people make their way now to Bohemia, now to Saxony, and then to Meissen, to Bavaria, and to Poland, to obtain such an indulgence." 112 There was also no shortage of people in Central and Eastern Europe willing to make a pilgrimage to distant places: Rome, Aachen, Compostela, and the Holy Land.

In my discussion above of the manifestations of collective piety, I have already mentioned several cases in which attempts were made to protect the fate of the immortal soul. Clauses contained in last wills and testaments calling for something to be left for monasteries and churches obliged monks and priests to carry out systematic prayers for the souls of the dead. Negligence in this regard provoked complaints from laymen, not only from those related to the deceased testator. We have not yet mentioned one important factor in late medieval piety, namely the mass intention for the souls of the dead, ordered with one's own soul in mind, or the souls of deceased family members, or-in the case of the residents of a city-the souls of members of religious and professional corporations. Let us recall that one of the main duties of members of a religious brotherhood or a guild, which brought together a large part of an urban population, was participation in periodic requiem masses for the deceased conferred upon the death of any member of these associations. Chapels established by the brotherhoods and guilds located in urban churches were the main places where requiem services were performed. The number of mass intentions for the souls of the dead ordered by particular individuals depended, of course, on their social standing, wealth, and generosity, and that number was often large enough to ensure the existence of the lower clergy, who performed such masses in numerous chapels and at an even greater number of altars in large churches in such urban centres as Prague, Wrocław and Krakow. If we consider that, in the parish church Saint

112 Ludolf von Sagan, “Tractatus de longevo schismate," ed. J. Loserth, Archiv für Österreichische Geschichte 60 (1880), p. 411. 
Mary Magdalene in Wrocław's Old City, the impressive number of 40,000 masses was performed at 58 altars every year, a large amount of which was performed in the name of the souls of the dead, we are then able to appreciate the extent of the devotion to those souls. The most costly chantry (so-called perpetual) masses were open only to the wealthiest people: rich burghers or the richer members of the nobility. A more popular manifestation of this kind of concern for salvation were so-called Gregorian masses, carried out over the course of 30 days after a person's death, and anniversary masses. Among the broad array of masses ordered by the faithful, the predominance of mass intentions for the dead, which is conspicuous in various lands, is confirmed by such detailed poll research as was conducted for the Tábor region of Bohemia in the pre-Hussite era. ${ }^{113}$ It transpired that that kind of dedication to the dead, shown mainly by the middle and lower nobility, grew significantly as a result of the plague that threatened in 1380 .

Masses for the dead, opposed at the height of the Hussite movement as a source for clerics to enrich themselves, and rejected by radicals for doctrinal reasons, returned later to Bohemian religious life, mainly among Catholics and to a lesser extent among Utraquists. Much like in pre-revolutionary times, we once again see examples of distinguished dedication, although the marked restraint here corresponded to the modest circumstances of the churches of both confessions; of course, those who distinguished themselves in this regard were representatives of the noble families who were not ruined by Hussitism. At the end of the fifteenth century, Henryk of Hradca established a chantry according to which two priests were supposed to perform, four times a week throughout the entire year, a mass for the deceased members of the family, for Wacław the bailiff, and above all "for our soul" and for "every Christian soul for which no one prays." People of more modest means, those who had at their disposal suitable material backing to establish a bequest, also considered their soul's future. Hanzlik, a baker from Vimperk transferred ownership of a meadow to the local church in exchange for two masses per year, performed during Advent, devoted to his soul and "all future souls" (that is, the souls of his descendants). ${ }^{114}$

Instruction in the notion of purgatory, pursued intensively by the Church in the fourteenth and fifteenth centuries, extended, as the faithful masses understood it, a person's biography beyond the boundary of divine judgment. Thus, during prayers and masses for the dead, the names of those dead were

113 F. Šmahel, "Dvanáct pramenných sond k sociálním poměrům na Táborsku od poloviny 14. do konce 15 století," Husitský Tábor 9 (1986-1987), 285 ff.

114 Z. Winter, Život církevní v Čechách, p. 860. 
scrupulously mentioned, as if the objective was to ensure that God would forget nobody. In this light, the complaint put forward by one of Prague's wealthy residents is understandable: during one visitation (1379), he claimed that, in days gone by, the names of the dead listed at the Church of St. Giles had been read out every day, but that was no longer done, and no one paid attention to the testamentary clauses. Bonds between the living and dead were strengthened, and prayers for dead relatives had an important goal, one that no one doubted. In prayer, a person turned to God to grant mercy "to the souls of all the faithful [...], and particularly the souls of my father, mother, brothers, sister, and all my friends." A bond with repentant souls was a reflection of the close bonds that mark the natural human family. People also prayed for other members of the community beyond the family, who were facing a transient, posthumous punishment: members of the orders, religious brotherhoods, and the parish. They prayed for the souls of dead relatives, but they also remembered the anonymous collective of souls that had departed this world. Polish prayers for the dead from the second half of the fifteenth century included calls for people to pray for those who were unknown, who had been forgotten, for those who had died a sudden death and whose bodies had not been buried. The priest called on the parish community:

I recommend particular mercy from us in our prayers for those souls whose bodies lay in this house [i.e. in this church] and in the cemetery. I also request from you one Hail Mary for those souls whose bodies died in battle, in the waters; I also ask for one Hail Mary for souls that have been abandoned, that are in the agony of purgatory, that have no assistance at all, that only look upon us and call out: have mercy, have mercy on us. ${ }^{115}$

It was believed that prayers for the dead contained something more than a response to pleas for assistance, because the exchange was also a matter of mutual cooperation, which also benefitted the living. In an old exemplum used in the fifteenth century in Hungary, we read about a young man who, every time he walked through a cemetery, offered a special prayer for all of the dead buried there. When his life came to an end, the priest said over his grave: "let him rest in peace," all of the bodies of the dead responded from their graves, in chorus: "Amen," 116 which confirmed their gratitude for have been remembered in prayer.

115 Kazania Gnieźnieńskie. Podobizna, transliteracja, transkrypcja, ed. S. Vrtel-Wierczyński (Poznan 1953), pp. 146-147.

116 Cornides - Kódex, eds. A. Bognár, F. Levárdy (Budapest 1967), p. 783. 
These and other actions and measures, regardless of the internal motives and feelings that accompanied them, mirrored the Christian world view that was, in various degrees, present among common folk. Whatever we think about the religious semi-literacy of a significant part of Central and Eastern Europe, including in particular its rural population, we must recognise that without a doubt the Church, over the course of its mission (which was shorter here than in the West, but still several centuries old), managed to inculcate the general population with the rudiments of faith, which included teachings about a human's final matters. In the parish church, as early as in childhood, the faithful learned the truths of the faith, which dealt with the immortality of the human soul and the dependence of its eventual fate on the person's temporal transgressions, his or her sins and good deeds, for which he or she would be accountable to God.

Church teaching, which had a broad vision of posthumous reward and punishment, did not disclose a unitary fate for the human soul; it concealed God's verdict from the living. This is why simple people, concerned about the fate of their deceased relatives, wanted to know whether their souls were in heaven or hell, and, not finding an answer in the church, asked old women about this, who clearly had ways of penetrating secrets beyond the grave. Occasionally, they turned with these issues in mind to the dying, who it was believed would soon be able to inform, if they wanted, living relatives about their own fate or about the fate of other people whom they had met in this world. The Church allowed for the appearance on earth of other-worldly apparitions, mainly tied to those in purgatory, but primarily when they had some constructive mission to carry out, one that was allowed by God and was not tied to the wishes of the living. Religious writings from countries in Central and Eastern Europe provide little evidence about those who arrived from the afterlife, particularly when we take into consideration stories of local origin, and not those that originated in the West. In this material, which contains evidence that is sporadic in nature, we would not be able to move around with such freedom as, for example, the medievalist Jean Claude Schmitt had in his book on apparitions that appeared to people living in the West in the Middle Ages. ${ }^{117}$

Texts of prayers and sermons, reprimands given to confessors, and illuminating religious readings, all reminded the faithful that only God knew what day would be the last of a person's earthly voyage. But the fact was that fortune-telling techniques revealed to people the future, and supposedly allowed them to learn

117 J.-C. Schmitt, Les revenants. Les vivants it les morts dans la société médiévale (Paris 1994). 
who among their relatives would die over the next year. The world of the dead approached the world of the living in the form of signals, some of which-accepted by the Church-were at work in religious didactics, others of which belonged to the sphere of folk culture and had not succumbed to Christian influence. In parables interwoven into sermons (exempla), visions from the world beyond were most often the privilege of saintly, chosen people, though they sometimes could serve to better a deserving sinner. In everyday reality, simple parishioners recognised the proximity of death in an owl's hooting, in the rumble of household machinery, and in various other signals that remained persistent in folklore.

\section{Traditional and Christian Beliefs}

The sphere of imagination and beliefs about life beyond the grave was an area in which religious syncretism was still strongly pronounced many centuries after the beginning of Christianisation. In Poland and Bohemia in particular, the old pagan other worlds, along with an entire system of old religions, were eclipsed by a collective oblivion. Certain nuggets, so to speak, of the old concepts of a human being's posthumous existence survived the abyss of memory; they were derived from what, at some point, had been cohesive systems, and, in the last centuries of the Middle Ages, they continued to coexist with those parts of Christian teaching that had been assimilated by the broader population. Traditional beliefs merged with notions of a person's material existence and the soul (not entirely detached from the body) after death. Gothic painting, in an attempt to find a compromise between the immortality of the human soul and the need to represent that immortality, depicted it either as a cloudlet emitted from the mouth of a dying person, or as an image of naked figures that are usually suitably miniaturised. Portrayed in the likeness of children, the souls of righteous people being carried away by angles to heaven were thus presented. However, in a painting of the Passion found in the Church of St. James in Torun, the soul of Judas, condemned for the ages, is portrayed no differently, ripped from his broken body by a heinous devil. We might well find other painted images characterising the saved and the damned. Traditional images were not, in this respect, consistent. In them, the souls of the dead could be invisible, and they could have an appearance that was unfamiliar to humans, because they would appear on earth at times when the living could not see them. In Poland, a domestic spirit-the spirit of a dead ancestor (in the fifteenth century, it was called "uboz"; that is, a "poor man" about whom nobody needed to care any longer) was most often conceived as a little old man. We might mention, by the way, that the Czech word nebožtík (in Polish nieboszczyk), before it began to mean "dead person," was used to indicate a "not 
rich" (that is, poor) person. Was it for this reason that Christianity denied him or her material support and gifts that had previously been provided?

The souls of the dead preserved certain temporal needs and preferences, and they displayed a tendency both to arrive on predictable dates and to appear unexpectedly, in their old, earthly surroundings. For the living, who hosted and supported them in various ways, the spirits of the dead could be benevolent or at least harmless, or they could be threatening and dangerous, and thus very unwelcome to the living.

Christian beliefs and attitudes regarding the death and burial of a human being, along with the ways recommended by the Church to support the souls of the dead, were interwoven with traditional beliefs and practices. A Christian funeral, participation in which was an expression of piety and devotion, and which involved, alongside other rituals and gestures, a string of prayers for the soul of the dead, was thus essential to that soul's salvation. Equally essential was the fact that the body would rest in a place close to the sacred, under the church's floor, in a more or less dignified place in the church or in the sanctified area of the cemetery, depending on the status, position and wealth of the deceased. There was a tendency in the fourteenth and fifteenth centuries for Church authorities to limit the burial of laymen inside a church principally to wealthy parishioners and to those whose service to the local church was outstanding. But in practice, the clergy often succumbed to pressures put on them by influential noble and burgher families who did not agree to have a relative buried in the cemetery grounds. Relatively recent archaeological work conducted under the grounds of the church in Radomyšl (Bohemia) ${ }^{118}$ revealed a much wider use of coffins than previously thought around the year 1500 for people belonging to the upper social strata. Paupers were buried naked or wrapped in straw, and most of the dead were wrapped in a shroud. Through synodal resolutions, the Church tried to ensure that poor peasants had a dignified burial. A synodal statute from the Diocese of Wrocław in 1446 ordered priests who administered the last rites to the dying to make no effort to distinguish between rich and poor. We do not know to what extent this directive was carried out.

One thing is certain: no one disregarded the matter of how they would be buried or where they would be buried. Regarding this stance towards death, which we might view as being universal, the views put forward by the Bohemian and Utraquist writer, Pavel Žídek are surprising. He complained that the dead in

118 F. Šmahel, “Archeologické doklady středověkě duchovní kultury," Archeologia Historica 15 (1990): p. 296. 
Prague were being buried in an undignified manner; that is, at churches where mass had not been celebrated for a long time. But what was perhaps worse, the dead were sometimes buried simply anywhere, even in fields, as if the object were not a human body, but a donkey carcass. Some of those who ridiculed all ceremonies declared: "It is enough that here lies a good person." 119 But this situation, in the middle of the fifteenth century, was peculiar: on the one hand, it was the result of a shortage of clergymen and other Church officials and, on the other hand, of the influences of various sects that rejected the funeral ceremony.

Among the carriers of traditional culture, there remained the motif, one which reached back to pre-Christian beliefs, that a properly conducted burial ceremony was essential, if not decisive, in influencing the posthumous success of the souls of the dead. To be sure, in the fourteenth and fifteenth centuries we no longer see the use of burial gifts, various kinds of objects that were supposed to serve the dead in the next world. They disappeared in the first centuries after Christianisation, and it would be difficult to draw a connection between modest ersatz objects, which remained part of funeral ceremonies in the Slavic countryside for a long time to come, and any kind of deeper layer of faith. We also do not see many or various human activities around the body and grave of a dead person that, according to ancient beliefs, helped determined a favourable existence in the afterlife; they had been forgotten or had been rooted out by the Church. However, deeply traditional beliefs remained, although formally Christianised and thus Church-supported, regarding the need to bury the bodies of the dead, quite separate from the fate of their souls, along with the attitude that a suitable and solemn funeral ceremony was an important step on the path to salvation. Moreover, faith in the effectiveness of all kinds of gestures directed by the living towards the dead continued to flourish.

The flames of candles placed at the bedside of a dying Christian brightened the darkness of his sins and accompanied, as shown in gothic paintings, the angels' battles against evil spirits over human souls, whose fate could waver until the very last moment. Later, lighted candles became an essential ingredient in a funeral procession and symbolised the bright and heavenly reality which the dead were entering, according to the hopes of the living. And yet we read this acerbic comment from a fifteenth century Polish priest: "Those view themselves as condemned behind whom no one will carry candles," ${ }^{120}$ which

119 R. Urbanek, op. cit., vol. 3, part 3, p. 776.

120 H. Zaremska, Bractwa w średniowiecznym Krakowie. Studium form społecznych życia religijnego (Wrocław 1977), $139 \mathrm{ff}$. 
testifies to the presence, including in urban and undoubtedly more Christianised environments, of the traditional attitudes that we discussed above. Let us continue for a moment with the theme of light and fire, which was extremely significant to matters (faith, beliefs, imagination) tied to eschatology. Lanterns of the dead, which were very well known in the West and which often came in the form of a high tower illuminating the darkness of a cemetery, were also something that could be found in Bohemia, Silesia, Poland and Hungary, ${ }^{121}$ although very few of them have been preserved. The light that they cast was to remind the faithful to pray for the souls of the dead buried there, but at the same time, according to the beliefs of simple parishioners, it encouraged spirits wandering around the cemetery to hide themselves in the graves. However, neither the light given off by candles placed around graves by pious relatives who accompanied the dead on their final journey, nor that which emanated from the lanterns over the deceased's final resting place, reached areas that were off the beaten track, where, following in the footsteps of their pre-Christian ancestors, rural folk set fires for the dead at those times when they were expected to visit earth. We will dwell for a moment longer at these fires, which burned at night not only in Slavic lands.

Traditional beliefs dominated the period between a person's death and the time when that person's soul departed for the unknown afterlife. According to the custom of their ancient forefathers, deceased Poles-more specifically, their souls-dwelled in and around the home after death, where they participated in traditional rituals that were reluctantly tolerated by the Church (as mentioned above, the Church stopped short of engaging in a decisive battle against certain customs such as this one). A collective meal was thus consumed in homage to the deceased person, which no longer resembled the funeral feasts from pagan times, but which was accompanied by the remnants of a belief that the deceased was actually participating. The ritual of tossing pieces (or perhaps just crumbs) of every meal eaten in memory of the dead was maintained in folklore. The OldBohemian language preserved archaic terms: the "supper of the dead," and "celebration of the dead," which nicely capture the belief systems at the heart of this custom. Synods at Gniezno and Wrocław in the fifteenth century called for moderation among priests participating in a funeral meal (or, more broadly, a wake), or they outright prohibited priests from taking part in such events.

Next, the "pusty wieczor," or the empty evening, the first evening after the death, when relatives, neighbours and friends of the deceased kept watch over his or her corpse. The Polish name for this ritual, which was prevalent in other

121 M. Vovelle, Les Âmes du purgatoire ou Le travail du deuil (Paris 1996), pp. 32-34. 
countries as well, indicated the specific situation of the person who no longer lived but who had not yet been buried and who was not yet dwelling entirely in the afterlife. In Old-Polish, the word "pusty" essentially meant abandoned, left without protection. In those days, it was up to the living to ensure such protection. In Bohemia, a person was supposed to "mourn," to find a way to "get over" the death, to "complain over the body," which sounds particularly archaic. As those who were not properly "mourned" suffered misfortune twice over, ${ }^{122}$ which was tied to that aspect of pre-Christian funeral ceremonies in which an essential role was played by ostentatious and noisy manifestations of grief, which were vital in determining a person's posthumous fate. Of course, the persistence of these traditional themes could coexist in full with the natural human sadness and grief that comes with the death of a loved one.

The motif of uncertainty surrounding the continued fate of the human soul has distant origins. In a Polish verse from the fifteenth century entitled "Dusza $z$ ciala wyłeciała" (The spirit departed the body), or the Bohemian and Moravian versions of that piece known to us from later ethnographic records, the deceased person's soul stands in a green meadow, disoriented and crying. The situation changes with the appearance of St. Peter, who takes the poor and miserable soul to heaven, although the presence of one of Christ's apostles could not fully detach this story's associations with traditional culture.

This motif of the loss of, or uncertainty surrounding, the human soul is also tied to other beliefs dealing with the early phase of a person's posthumous fate, beliefs which had clearly been Christianised, but which were not identical with official Church teaching. The text of a sermon that was well-known in Poland in the fifteenth century conveys one version of the path that a human soul could take. In this version, souls spend the first two nights in the company of saints (the first night with St. Gertrude, and the second night with St. Michael), and only later do they make their way to their designated place of eternal rest. According to beliefs at the time, both saints were proven protectors of the souls of the dead. Folk beliefs adapted such a version of the first phase of posthumous existence by changing the names of the characters serving as holy protectors, but the "proper" specialisation of the chosen saints remained the same.

It seems that, with our current considerations in mind, another motif was more important than the choice of different saints, namely that of the three days during which the dead bid farewell to their earthly environs and slowly, step by step, crossed the border between what was temporal and what was eternal, 
between what was worldly and what was holy. In later times, that period would be extended to 30 and up to 40 days.

However, in the burial of a body, efforts were usually made to mark an end to that person's earthly activity, in part because of fears that the dead would persistently return from the grave to the household, beginning shortly after burial. Perhaps such fears were tied to the archaic belief that a failure to carry out a proper funeral ceremony, and thus negligence in caring for the dead and their fate in the afterlife, had consequences. Stanisław of Skarbimierz, a consummate expert on traditional beliefs and practices, condemned as superstitious methods designed to prevent the return of the dead, ${ }^{123}$ among which he mentioned the acts of spreading ashes at the threshold of the dead person's home (in old Ruthenia, the presence of navi-the spirits of the dead-could be detected by the tracks they left in the ashes), or of burying objects under the threshold that were thought to have some kind of magical significance.

\section{Categories of the Dead}

Folk beliefs still recognised the existence of several categories of the dead; for example, the souls of deceased ancestors (in Polish, $d z i a d y$ ) who had died a natural death and had been given a proper burial, who thus dwelled on earth and were friendly to the living, and who expected from the living a warm reception and certain hospitality. For now, we can pass over other kinds of dead: strangers, enemies and those that posed a danger to the living. The assistance of deceased relatives, dwelling on earth at established and predictable times, was of course not synonymous with disbelief in the methods provided by the Church. No doubt even the simplest people maintained faith in the effectiveness of the mass for the dead, of obsequies, and of prayers for the dead, but in their minds, these Christian offerings did not satisfy all of the needs of the deceased, namely those that the priests did not want to recognise. Also telling is the fact that, in the folk imagination at the end of the Middle Ages, the day of 2 November, celebrated in the Church as All Souls' Day, was not associated with the invasion of earth by the souls of the dead. It was rather a time to participate in solemn liturgical rituals and engage in common prayer under the leadership of the priest, which was not identical with the time spent in contact with the dead. In Polish and Bohemian lands, beliefs were tied to many "all souls" dates, among which were archaic dates

123 Stanisław of Skarbimierz, Sermones Sapientiales, ed. B. Chmielowska, vol. 2 (Warsaw 1979), p. 87. 
associated with springtime, situated in the Late Middle Ages around the Christian day of Maundy Thursday. As mentioned above, fires were set for spirits dwelling on earth in mass numbers. One Polish author of sermons in the fifteenth century had no doubt that such behaviour was a mark of pagan custom and, as such, was reprehensible, though he recognised that it was practiced to remember the souls of deceased relatives. ${ }^{124}$ Generally speaking, however, no one doubted that such fires offered corporeal assistance to souls arriving from the afterlife: those souls would cosy up to the fires to warm themselves. Quite clearly, the fires of hell and purgatory, which were well known from Church teachings, and which had a powerful impact on the faithful's imagination, had not yet burned away the dark and cold posthumous spaces of old Slavic beliefs. Certain memories of those spaces, of which people were no doubt only vaguely aware, coexisted with the Christian spaces of posthumous punishment. From old Ruthenian sources referring to the first centuries of Christianity in that country, we read of food being prepared for the souls of the dead, which included meat and milk, eggs and cakes baked in ritual shapes, beer and liquid honey. We see some of these same foods many centuries later in ceremonies for the dead on Polish lands, which would indicate that this Slavic tradition of ritual foods was persistent. In the same vein, we learn from fifteenth century sources that leftovers from meals, or perhaps, as Stanisław of Skarbimierz wrote, simply unwashed dishes, would be put out on nights during the Holy Week so that the souls of the dead could have something to eat. ${ }^{125}$ And once again, we see the term Maundy Thursday, assimilated by folk culture, used as a date on which the souls of the dead are expected. In central Poland, in times not far from our own, the following words were sung during Easter.

W Wielki Czwartek, w Wielki Piątek Cierpiał Chrystus za nas smętek Piętrze, Piętrze weź te klucze Idź do Raju wypuść dusze.
On Maundy Thursday, on Good Friday Christ suffered for our grief Peter, Peter, take the keys Go to Paradise, release those souls.

As a synod ban shows, in Transylvania as well the faithful were still lighting fires and preparing food on Maundy Thursday, "purportedly so that the dead could warm themselves and have something to eat." ${ }^{\text {"26 }}$ On Christmas Eve in

124 E. Belcarzowa, Głosy polskie w łacinskich kazaniach średniowiecznych, part 1 (Wrocław 1981), p. 57

125 Stanisław of Skarbimierz, op. cit., vol. 2, p. 90.

126 A. Pippidi, "Vision de la mart et de I'au-delà dans les anciennes sources roumaines," Revue Roumaine d'Histoire 33, No. 1-2 (1994), p. 95. 
Bohemia and Poland, people hosted the dead, who visited their old homes and ate food put out for them after their relatives had fallen sleep.

In many regions of Europe, a tradition was carried over from folk tradition (in many lands during the Middle Ages) by which certain kinds of work, household chores, and everyday gestures were prohibited during days on which the dead visited earth. People avoided, for example, pouring water, sweeping rooms, and painting walls, in order to not drive away invisible "spirits" or disturb their peace. Several groups of beliefs involved prohibitions on sewing, weaving and spinning on these days. In ethnological studies devoted to bans involving magic, authors noticed an almost complete lack of such bans on Christian All Souls days; and they noticed that most of them were focused around folk observances of Christmas, which we might well argue indicates traces of old beliefs hidden under the cover of a Christian holiday.

We know of the gratitude shown by the dead for the assistance received from the living largely through its Christianised version, which spoke of intercession with God by souls dwelling in the afterlife in exchange for prayers on their behalf. Below we will see an example of this. Gratitude could also emerge in a more temporal, mundane context. Based on the content of an exemplum that was well known in the Middle Ages, an epitaph image by Sivert Granzin from the collegiate church in Kołobrzeg (1492) portrays a knight who, while searching for protection in a cemetery during his flight from the enemy, gets help from the dead rising from their graves who were grateful to him for the prayers he had said on their behalf. They are equipped with weapons and work tools that characterised what had been their earthly status or profession. One motif that rambles through folk tradition, but which is barely perceptible in medieval sources, involves assistance provided to the living in vital, everyday matters by the dead, in which they showed care and concern during their visits on earth. It is worth recalling, by the way, the ancient belief in the stimulative role that the dead played in the planting and harvesting of crops cultivated by humans, particularly in the spring, when nature was coming out of its winter sleep.

The souls of the dead also dwelled on earth who were not friendly to the living but who were also not very threatening; rather, they exhibited a tendency to frighten a person by surprising him or her with their appearance or voice. This phenomenon had its origins in archaic beliefs, on which was based the Christianised theme of penance for unexpiated guilt. These sad souls, doing penance, could find themselves in a wide variety of places: around a grave, at the place where a sudden death occurred, under stones or bridges, at crossroads, in caves and wells, under thresholds and inside homes. 


\section{Ghosts}

Western-Slavic folklore also perpetuated a fear of the actions of the "bad" dead, which were decidedly harmful to people and their lives, including those dead who had left this world in a way that was sudden, undignified, etc. Thus, efforts were made to bury a person who had been hanged away from built-up areas and cultivated fields, where that person could bring violent winds and hail. People feared those who had drowned, evil and insidious as they were, who drew bathers into their whirlpools. Even in more recent times, we could witness attempts in certain places to "placate" these souls by tossing food into the watery depths where people most often drowned. The dead who posed a threat to people, and who frightened others, appeared on earth usually in bodily form, often deformed, as distinct from those souls, discussed above, who were disembodied and invisible (but who, nonetheless, had material needs). Traditional Slavic culture gave them certain shared external features: dark or red-tinged skin, fiery and glistening, rather short in stature, covered in dense hair, thick eyebrows, a large head, large teeth and eyes, over-sized hands, a limp, and the feet of an animal, often a bird. Many people in middle Pomerania believed that it was only by the darkred colour in the face that a ghost could be distinguished from a common dead person. There is no doubt that at least some of these features, which we know from ethnographic sources, are tied to elements of a highly archaic imagination.

Deceased individuals from this category did not take into account the dates on which people expected them; they appeared unexpectedly, perhaps at the place of their death, or they came from an unknown direction, or they left the graves in which they had been buried, in so doing frightening the living. The living attempted to put up opposition in various ways. The author of a study cited above states:

The dead who, in life, were bad people, according to traditional beliefs about the continuation of the dead's continued earthly existence, remained bad after death. Efforts were made to bury bad people far from inhabited areas. A wide variety of measures were also taken to keep the corpse in the ground. Planting briers around the burial site, binding the corpse's limbs, and puncturing the corpse, were practices well-known in Poland until the nineteenth century. Belief in the need to prevent the dead from harassing and harming the living also influenced, it would seem, judicial practices. It is probably the case that the death penalty, by beheading or quartering, was tied to the old custom, known in German circles, of "killing" the ghost. [...] Judicial practices were also penetrated by the custom of driving a stake through the bodies of those buried alive. ${ }^{127}$

127 H. Zaremska, “Człowiek wobec śmierci. Wyobrażenia i rytuały," in Kultura Polski średniowiecznej XIV-XV w., ed. B. Geremek (Warsaw 1997), pp. 500-501. 
The motif of the "living corpse", a ghost imagined in material form that the living were trying to destroy, which-thanks for example to Caesarius of Heisterbach and his wonderful Dialogus miraculorum-was well-documented among the Germans and remained at work in Central Europe at the end of the Middle Ages. ${ }^{128}$ In the fourteenth-century work of the Bohemian chronicler Jan Neplach, under the year 1336 we read about the frightening posthumous feats of a shepherd named Myslata ${ }^{129}$ (we should mention, parenthetically, that the connection between shepherds and goatherds and magic and sorcery survived into modern times). Having risen from his grave, Myslata wandered among homes at night strangling people he met and screaming out the names of others, who, having heard his voice, died several days later. Traditional methods known throughout the countryside to destroy the "living corpse," including driving a stake through its body, did no good. The threatening and, at the same time, contemptuous ghost mocked his pursuers, saying: "They gave me a stick, with which I will be able to defend myself against dogs." Only when, after several failed attempts, his horrible body was completely burned did he lose his power and his "thorough evil died away." The chronicler, as if encouraged by the attractiveness of his story, added further such content. This time, it was a female ghost who also frightened and killed the living. Once again, we are faced with the motif of the burned corpse as one of the most effective ways to destroy the ghost. We need not reject either of Neplach's stories as inauthentic in that they may well have originated in the Middle Ages folklore of the Bohemian countryside. Having said that, they contain threads of beliefs that are extremely diverse, no doubt archaic, but with a broad reach throughout various regions of Europe. It is appropriate that we leave unanswered the question of whether the motif of the dangerous ghost and his "killing" by the human community was native or an import. Here, a very important aspect is, of course, the cleansing and destructive power of fire; I have already emphasised its role in annual folk rituals meant to destroy demonic beings.

The Church rejected the belief in corporeal ghosts that were hostile to humans. It took a critical stance of initiatives to put up a defence against them or similar categories of the dead, as it did towards the spread of non-Christian assistance to those arriving from the afterlife. Bohemian villagers (and, in fact, residents of

128 See particularly the work by E. Potkowski, Dziedzictwo wierzeń pogańskich w średniowiecznych Niemczech. Defuncti vivi (Warsaw 1973).

129 "Neplacha, opata Opatovského, krátká kroníka římská a česká," ed. J. Emler, in Fontes rerum Bohemicarum, vol. 3 (Prague 1882), p. 460. 
other countries) tormenting a corpse that had been dug out of its grave doubtlessly knew of these bans, but they ignored them. We might suppose that they did not associate where its soul resided with any defined space in the afterlife. Or perhaps they associated it with hell? I doubt this. However, it is difficult to doubt that these simple people, living among spirits and ghosts with ancient origins and pondering their own posthumous fate, expected their spirit, perhaps after a period of wandering, to end up in heaven (most certainly after a stop in purgatory), or-God forbid-in that place where the condemned burn in eternal fire. 



\section{Imagination and the Afterlife}

In most versions of Dialogus Magistri Polycarpi cum Morte, which was extremely popular at the end of the Middle Ages, and which was published in several editions and translated into various languages, omnipotent death judges people in a simple way: it directs the good towards heaven, and the bad towards hell. However, in some versions of this text such an absolute verdict gives way to one that is more nuanced. While the good have earned their way into the Heavenly Kingdom, the bad go to hell, the moderately good go to purgatory, and unbaptised children enter limbo (usually known as the Limbo of Infants, or limbus puerorum). ${ }^{130}$ The authors of these versions of the work thus revealed that they cared about a theologically correct presentation of the structure of the afterlife of Western Christianity, according to eschatological knowledge as formed over the previous centuries; they were familiar with the very same other-worldly spaces that the great theologians of the thirteenth century (Thomas Aquinas, Bonaventure, Albertus Magnus) had discussed in their works. The moralistic nature of the work allowed the next and final place to be overlooked: the abandoned abyss of the Old Testament prophets (limbus patrum), liberated by the resurrected Christ. This system of four or five spaces where the posthumous human spirit might reside was brought to bear in scholarly theological works, less often in sermons and religious literature intended for a lay audience. In Western Europe, this system was also reflected in mural paintings, examples of which are, admittedly, sporadic, but which often present a monumental vision (the frescoes in the cathedral at Salamanca, and above all the representation of the Coronation of the Virgin in the Villeneuve-lès-Avignon, an integral part of which is a depiction of the afterlife with its five spaces). In Central and Eastern Europe, there was no such broad representation of the afterlife in gothic painting or sculpture. But this fact is not truly significant. Church teachings, as was the case throughout all of Western Christianity, presented three basic otherworldly spaces: heaven, hell, and purgatory. Each of these three spaces, taken individually, was surrounded by a kind of dialogue between the content of instruction conveyed by the Church and its reception among the faithful, and the popular images of the afterlife. Folk beliefs, even if they did not actually undermine this three-part system of the afterlife, blurred the borders between it parts, and

130 C. Pirożyńska, “Łacińska 'Rozmowa Mistrza Polikarpa ze śmiercią,” in Średniowiecze. Studia o kulturze, vol. 3 (Warsaw 1966). 
imposed on this system its own concept of the relationship between residents of the afterlife and people living on earth. Having said that, in Bohemia in the fifteenth century, this dialogue collapsed. The Catholic image of the afterlife, which was based on the threat posed by traditional beliefs, was destroyed by the doctrinal and ideational positions introduced by the Hussite movement.

\section{Imagining Heaven-Paradise}

An essential part of the Christian doctrine of the eternal reward, formulated (if we are talking about the Roman Church) in official papal rulings and during ecumenical councils, was to behold God directly. Thus, the faithful were taught that human souls, cleansed of sin, and beholding God himself in heaven, experienced true bliss. But the Church authorities sensed difficulty in terms of how this teaching was received by laymen whose imagination lacked sufficient preparation, not to mention by the most simple country folk. Beyond that, serious difficulty was related to the non-material nature of human souls dwelling in the afterlife, who had been deprived of all temporal needs, and who would take earthly shape again only after the Last Judgement. It transpired that, in descriptions of eternal remuneration directed at the faithful; for example, in collections of Sunday sermons, it was not easy to refrain from referring to matters associated with a person's temporal existence. Thus, descriptions of heaven-paradise were quite often the result of a compromise, in which attempts were made, more or less effectively, to avoid too much materialisation of the religious vision. When addressing the Christian masses, the Church authorities tried to restrain hopes in obtaining a full picture of what, according to the Bible, the human "eye hath not seen, nor ear heard." They perpetuated the motif that it was impossible to describe the place where they would find eternal reward. A Hungarian compiler of parable collections assembled shortly before the Reformation resorted to expressive metaphor:

Even if the entire world became parchment and all the seas became ink, if all of the trees and grasses transformed themselves into writers, and if all of the people who have ever been, and ever would be on this earth, also became writers, it would still be impossible to describe the enormity of the heavenly reward. ${ }^{131}$

Some theologians and priests, however, emphasised in their teachings the great difficulty of achieving salvation; indeed, that salvation was a rarity. They reminded the faithful of the warning from the Gospel that many would be called,

131 Peldak Könyve 1510, ed. A. Bognár, F. Levárdy (Budapest 1967), p. 113. 
but few would be chosen. In fact, occasionally they took their interpretation of this warning to an extreme, for example with a sermon contained the exemplum about the day on which St. Bernard died, and on which 30,000 human souls stood before the countenance of God. St. Bernard and a certain monk were offered salvation, the souls of three others were assigned penance in purgatory, and the rest sentenced to eternal damnation. In the fifteenth century, Jacobus de Paradiso, a Cistercian and Carthusian monk who, through his work, was tied to both Polish and German lands, cited the above-mentioned exemplum, and argued that the world in his day-300 years after the death of Bernard-was much worse than ever before, and that the number of people who could expect salvation would have to be even lower. ${ }^{132}$ This motif of salvation's rarity seemed to affect relatively few people, those who were more sensitive than average. This group no doubt included the Prussian mystic and visionary discussed above, Dorothea of Montau, who assured her spiritual guardians that only a few souls would make their way directly to heaven after death. However, not many laymen buckled under the burdens of sin like Dorothea did.

In various religious texts, people who were particularly pious, saintly or deserving of God revealed themselves to the living in order to notify them of their salvation, and their life and death became an inspiring example for others to imitate. The living could also identify the salvation of the chosen through signs. Teutonic knights had no doubt that the souls of their brothers who had fallen in battle against the pagan enemy had gone straight to heaven. They were strengthened in this belief by their fires and candles burning on the battlefieldssigns of salvation for those who had given their lives for the faith and the order.

Church authorities attempted to depict any joy that the chosen might feel, joy that might well transgress the fundamental albeit complicated motif of communion with God, very carefully and in small doses, which were supposed, in some way, to bring the individual closer to the incomprehensible and unimaginable whole. In this context, stories about miraculous scents and sounds coming from heaven, which the chosen on earth recognised with fascination, were significant and eloquent. The very same Church authorities were also glad to resort to various kinds of comparison. A collection of parables that appeared in Hungary included one about a monk and his beautiful voice, whose songs delighted a swallow so much that the bird flew to where the monk was sitting in order to sing along with him: "So if an unthinking little bird found such satisfaction in

132 Jakub z Paradyża [Jacobus de Paradiso], Wybór tekstów dotyczących reformy Kościoła, ed. S. A. Porębski (Warsaw 1978), pp. 342-343. 
a person's singing, what great pleasure there will be in heaven where the angels, the Virgins and the saints sing." ${ }^{133}$ In one of his Sunday sermons, the Hungarian Franciscan Observant Pelbartus Ladislaus of Temesvár explained that, since God bestowed upon the world thousands of things that people desired and that delighted them-wonderful and sweet-smelling flowers, precious gems, silver and gold-heaven will transpire to be even more beautiful. Indeed, a world filled with these and other such splendours is to heaven what an animal stable is to a beautiful palace. ${ }^{134}$

In the medieval image of the afterlife, the space of eternal reward, as compared to the space of eternal damnation or purgatory, was marked by generalities and frugal imagination. When it came to depicting heavenly reality, the notion that the joy of the chosen was so unimaginable, and that the space they occupied was so wonderful that it could not be described, it paralysed creativity. Exempla woven into sermons, which usually originated in Western Europe, warned against making references to earthly joys that were too bold, such joys being sinful, frivolous, and transient. In one such story, a knight (and hunter by avocation) found himself being reprimanded by his instructor/clergyman for the fact that he expected that he would find birds and hunting dogs in heaven.

The idea was that those who had received salvation would take part in the common joy that came with the magnificent and delightful reality found in the place of eternal reward. Stanisław of Skarbimierz, who, in his sermons, developed his vision of heaven around the motif of a city made of gold, also likened heaven, consistent with earlier tradition, with a great church in which grand liturgical rituals were performed without end. ${ }^{135}$ Church music and the singing of religious hymns were dignified and solemn, and the joy of those who had found salvation engendered fascination and deep emotion. But the liturgical gravity of ritual often stood in conflict with many hymns, especially those that spoke of joyous events. In fulfilling their didactic function, they spoke above all to the feelings of the broad community of the faithful. In Polish hymns, angelic song would often be "sweet" or "greatly sweet," while angelic music, played on various instruments, cheered and encouraged the saved.

133 Cornides - Kódex, ed. A. Bognár, F. Levárdy (Budapest 1967), p. 579.

134 Sermones pomerii fratris Pelbarti de Themeszwar "De tempore" (Hagenau 1498), sermons XV and XVI.

135 Stanisław ze Skarbimierza, Sermones super "Gloria in excelsis," ed. R. M. Zawadzki (Warsaw 1978), pp. 36-37. 
In selecting a model for the grand city, Stanisław of Skarbimierz did so in the conviction that nothing could better express the perfection that was the place where the chosen dwelled, and nothing could cause greater excitement among those listening from church pews. He described a vision of glittering abundance: gold, roads of precious stones and pearls; that is, that which, in temporal life, not only constituted human wealth and power, but also caused great delight. He portrayed a city with roads paved with pure gold, gates made with pearls, and buildings constructed with sapphires and covered by roofs made of gold. These were traditional building materials, with little that was innovative, which were known above all from the Book of Revelation (the Apocalypse) and from earlier descriptions of other-worldly visions. The urban character of this described space highlighted, almost exclusively, its architecture: heaven's towering buildings, walls and gates.

In later religious texts dating back to the end of the Middle Ages and the beginning of the modern era, heaven was located in magnificently built palaces. Pelbartus of Temesvár explained that the splendour of the heavenly palace had to be worthy of God's majesty. In homiletic exempla, access to such palaces was, of course, closed not only to notorious sinners, but also to those who had not yet atoned for even their least burdensome sins. Among those who could not enter were a knight-oppressor of the poor, along with a certain upstanding guardian of the Bernardines, who had heard in a dream the "sweetest angelic singing" and caught a glimpse of the "palace most splendidly prepared."

Paradise-the beautiful garden, which in late Gothic painting in Western Europe featured the distinguished grace of court culture-was marked in Central and Eastern Europe by the modest realities of the fruit and flower garden. St. Dorothea seemed to speak of just such a place in a Bohemian-Polish legend put to verse: “ $[. .$.$] where I will pick all kinds of fruit, apples, and flowers." In a mural$ painting in a church in Silesia, the place in which the Madonna and the Baby Jesus find themselves in the company of the Holy Women is a small corner of a garden with trees populated by birds, with flowers in bloom, with green grass. This garden is set apart from the surrounding space by a wickerwork fence, primitive but tight, which served as a modest equivalent of the urban walls with mighty towers surrounding the heaven-city.

Both visions of heaven (the garden and the city) were never too far from the motif of heavenly abundance, affluence, and satiety, which were highly attractive qualities in the collective imagination. Even though there were biblical models to choose from, other visions lay in wait, visions of various utopias and prophecies describing the future happy existence that the Church treated with reserve. In the old apocryphal text, which came from the East, known as the Vision of St. 
Paul (or the Apocalypse of Paul), which was widespread at the end of the Middle Ages in various languages, the paradise of the saved was described as a kingdom of material abundance, with rivers of milk and honey, wine and olive oil. The spiritual aspect of the eternal reward seemed to co-exist with the motif of human desires fulfilled.

In presenting spiritual reality, the texts of sermons (whose goals, after all, were a matter of mass religious didactics) exhibited the conviction, mentioned above, that people could not utter references to what they truly thought, imagined, and felt. Authors of such sermons wanted to avoid attributing those qualities and needs that characterised mundane existence to the non-material souls of the saved; thus, they associated heavenly existence with liberation from any deficiency, any torment, and any threat. In the end, it proved difficult for even the most seasoned of theologians to follow this policy, particularly for authors of lower flying religious texts, composers of hymns, etc.

Visions of paradise for the saved, including those that Stanisław of Skarbimierz sketched out in his sermons, contained the motif of compensation for people who felt that, in this world, they had been poorly fed and clothed. The Cracovian scholar assured the faithful that, in the eternal kingdom, there would be no food source that could be exhausted or spoiled, no drink that runs out, no clothing that gets old. In this way, he intended to indicate that all of this world's existential concerns were transitory and, in the afterlife, non-existent. However, in later reflections he came dangerously close to the border separating a spiritual vision of Christian paradise and utopian lands of satiety. He explained that in affluent and bountiful heaven there was an abundance of everything that was grand and brilliant. There, food does not burden the stomach, it never has an unpleasant taste and is never repulsive; everything there is fragrant and sweet.

From Polish writings, let us quote two descriptions of the conditions of heavenly existence, which emerged from different religious environments and distant from one another in time, but which were nonetheless related in that they appealed to similar feelings, and similar imaginative elements, on the part of listeners. In the sermon mentioned above, Stanisław of Skarbimierz described a place of eternal reward in which a person was never confronted with anything unpleasant, anything that caused bitterness; in which no one spoke about torment; in which there were no sicknesses, no infirmities, and no suffering. The lightning that frightens people on earth does not strike in heaven; there are no torrential rains, no terrible winters, no exhausting heatwaves, no destructive fires, and no pestilential winds. Peace and rest are omnipresent; no one is harassed, or accused; no one grows old, dies, or becomes weak. At the same time, in Rozmyślanie przemyskie (also entitled Rozmyślanie o żywocie Pana Jezusa, or 
Reflections on the Life of the Lord Jesus), an apocryphal work from the end of the fifteenth century whose origins are usually associated with the Franciscan Order, we read the following about paradise:

Summer is never [too] hot there, and winters are never too cold. There are no tears, no sighs, and no fear. There is no hunger and no thirst. No one is inflicted with ulcers or abscesses or other aches and pains. There are no sicknesses there, no one dies of old age. And no one grows infirm through laziness. Eternal joy and good cheer, safety, health and everlasting peace. ${ }^{136}$

The reality of the chosen people's existence was thus presented as liberation from the evil and suffering that dominated life on earth. Descriptions of paradise were also simultaneously a register of earthly fears and threats. In assurances that the saved would not have to worry about food shortages or inadequate clothing, we see reflections of the elemental concerns of human existence. Church authorities commonly referred to the images of the social imagination that were powerfully dependent on natural phenomena and nature's whims, and which were often the cause of disaster and misfortune. The promise that people could be liberated from the damage and destruction caused by heavy rains, storms, and fires doubtlessly spoke loudly both to those who lived in cities and to those who lived in the countryside. The fact that the above-cited descriptions presented paradise as a place that lacked freezing weather and heat waves could suggest that they were directed at people who were poorly clothed and hard-working. Less often, visions of heaven were directed at the peasant population-as we see from a Polish song from the beginning of the sixteenth century-with promises of liberation from hard work in the fields:

You don't have any trouble there,

No cold, and no heat and sweat;

There'll be no need to work hard,

No need to scythe or to plough the field. ${ }^{137}$

In many descriptions of paradise we find traces of fears that accompany people in their daily lives, including the fear of disease, which was often associated with pain and suffering, and which sometimes came as a result of social and material degradation. There can be little doubt that fear of infirmity with age was no less significant and widespread, and eternal youth and health represented an important guarantee, for the chosen, of a happy existence.

136 Rozmyślanie przemyskie, in Średniowieczna proza polska, ed. S. Vrtel-Wierczyński (Wrocław 1959), pp. 140-141.

137 Średniowieczna pieśń religijna polska, ed. M. Korołko (Wrocław 1980), p. 256. 
The motif of salvation as compensation for deficiencies and anguish during life on earth was tied to the promise of a reward in heaven for exemplary Christians. Stanisław of Skarbimierz noted that: "the harder people's experiences were on earth, the more joyous they are" in heaven, by which he meant experiences suffering for God and justice. However, through the promise of liberation from all the torment and injury experienced among humans, the motif of compensation took on a second, more earthly dimension.

\section{Visions of Eternal Damnation}

The person who directed his or her hopes towards heaven - that place of eternal joy-and towards that reward in paradise for earthly torments and deficiencies, could not forget about the other, terrifying prospect of existence in the other afterlife: the eternal punishment that awaits the intransigent sinner. The Church reminded people of this option in every accepted form of religious instruction, which affected the natural human fear of suffering, which in hell would never end and was supposed to be greater than the most severe suffering ever experienced on earth.

Teachers of the faithful interpreted eternal posthumous punishment as the effect of divine punishment imposed on those who, by their own free will, had chosen evil. At the same time, they taught that such punishment was not contrary to divine mercy. However, in the human consciousness, this truth of the faith could co-exist with the representation of a powerful and angry god, one capable of taking revenge for an insult or lack of obedience. In eschatology, the old Polish and Bohemian languages combined punishment and revenge conceptually; thus, in hand-written Latin sermons, copied in Poland in the fifteenth century, we find the following text added to a request to stave off eternal punishment: "Do not take revenge on us for our transgressions."

At the end of the Middle Ages, the Church authorities grew concerned about how to instruct the faithful on matters related to punishment after death and the location of eternal damnation. According to recommendations issued by the Bishop of Krakow, Wojciech Jastrzębiec, in 1423, priests delivering sermons were to be particularly moderate and careful in this regard, which was a principle that was supposed to guide how the faithful would be presented both with the threat of hell and the severity of divine judgment, as well as with the hope of salvation. Confessors received similar instructions. At the beginning of the fourteenth century, the Bishop of Wrockaw, Nanker, repeated in his statutes a view that was already prominent in the West, namely that a confessor should not rail against a penitent and not drive him or her to extreme desperation (or to doubt that his or 
her sins could be forgiven). Similarly, in later diocesan statutes issued in Polish lands, the Church authorities ordered priests to be moderate in their efforts to lead the faithful to contrition and admission of their sins. Only in cases in which the penitent resisted or was incorrigible were confessors supposed to present him or her with the threat of divine justice, with eternal punishment in hell, and with the frightening vision of demons.

The Church in Poland thus did not prevent priests from mentioning the threat of posthumous punishment, although it did recommend that they exhibit care and moderation in this regard. Such policy also seemed predominant in the Bohemian church in the pre-Hussite era. Of course, the diocesan reality in both Bohemia and Poland was sometimes quite different; for example, Jan Hus knew of priests who would frighten peasants with eternal damnation, which he naturally regarded as an admirable reprimand. Nevertheless, in light of research in sermon collections, it does not appear that, in either Bohemia or Poland, fear of hell was a didactic tool that was important and commonly used. This comment can also apply to the religious didactics used in Hungary in the second half of the fifteenth century, despite the fact that one of the topics most often raised in sermons from this period was infernal punishment.

In scholarly works, above all in theological treatises, when addressing the matter of eternal damnation, authors highlighted the possibility of depriving the faithful of the opportunity to behold God. This truism of faith was also passed on to the lay faithful, and Church authorities facilitated their understanding of this by reminding them that the joy of paradise, already set out for them, could be lost, and that hell was filled with darkness, through which they would see only terrible figures of devils and the suffering of the condemned. In the second half of the fourteenth century, an Austrian preacher in Prague, Konrad von Waldhausen, told his listeners: "Many fear the torment of hell, but I say to you: the torment that comes with not beholding the countenance of the Saviour is much greater." ${ }^{38}$ Authors of other religious texts intended for wider circulation faced the difficult problem of how to maintain a proper balance between two aspects of the punishment of eternal damnation: being deprived of the blessed vision (of the possibility to behold God), and the physical suffering felt by the human senses; as a result, the didactics behind the forfeiture of the vision of God, which spoke to the collective imagination with difficulty and was not described in Church paintings, generally remained enigmatic and declarative, which is why

138 F. Šimek, Staročeské zpracování Postily studentů svaté university pražské Konráda Waldhausera (Prague 1947), p. 101. 
many churchmen simply gave up in this regard. It is worth pointing out that even in collections of religious texts as exceptional as the royal prayer books of the Jagiellonians, which were prevalent in the fifteenth century in Poland, Bohemia and Hungary, there was talk only of the physical suffering experienced by the condemned.

In accordance with the stance taken by the Church Fathers, the faithful were inculcated with the belief that punishment in hell was significantly harsher and more painful than any sort of earthy punishment. This is why Dorothea of Montau, talking to her spiritual guardians about her other-worldly visions, did not fail to add that the sight of hell and devils would have to harm any person not under divine care, including the canons of Kwidzyn. In an exemplum used in the fourteenth century by Peregrine of Opole, the Silesian author of a collection of sermons that were extremely popular in Central Europe, a pious woman tried to instil in her sinner-husband the exceptional severity of infernal punishment. Drawn into hell by the devil, he later returned to earth, half charred, in order to testify to the punishment he faced. The soul of Konrad von Wallenrode, the Grand Master of the Teutonic Knights, which in his enemies' opinions had been condemned to eternal damnation, appeared in one of Dorothea's visions "terribly deformed," "burning like a fire and resembling a demon." 139 In later sermon collections, the eternal fire, although similar in quality to an earthly fire, was the most painful source of a condemned person's physical suffering. Osvaldo de Lasko asked his no doubt concerned listeners: Can the infernal fire be assuaged? A question he answered without hesitation: "in no way." 140 Dangerous fire and destructive forces, capable of annihilating all of a person's possessions, especially in countries with structures made mostly of wood, and capable of causing terrible pain, had an effective influence on the human imagination. The damned destroyed by fire, examples of which were woven into sermons, invoked a vision of human bodies burning in earthly fires.

Preachers in particular who spoke of the punishments in hell would appeal to the human imagination and refer to phenomena and experiences that were commonly known. In one of his sermons, Osvaldus de Laska described, in precisely this way, the suffering of the five senses that the condemned would have to bear. They thus see in the hellish darkness surrounding them terrible and

139 Johannes Marienwerder, “Appariciones Venerabilis Dorotheae," in Scriptores rerum Prussicarum, ed. M. Töppen, vol. 2 (Leipzig 1863), p. 372.

140 [Osvaldus de Lasko], Sermones dominicales perutiles Biga salutis intitulati (Hagenau 1506), p. 139. 
frightening demon figures. Were a living person to see them, he or she could not withstand such a vision long enough to say a single Lord's Prayer, for he or she would die immediately. A condemned person would have to bear hearing incessant noise and terrible groaning and complaining, howling and devilish screams, such that even the entire world burning in flames would be quieter than the roar in hell. The condemned give off such a hideous stench; corpses decaying on earth do not smell as disgusting as the bodies of the condemned. When it comes to the sense of taste, hunger and thirst dominate all other examples of torment, because no one can imagine the vast thirst felt by those who would drink an entire sea but are not able to get even a single drop of water. Through their sense of touch, the damned are condemned to unending agony since none of their limbs is healthy. Were someone to touch their head or feet with a blade of grass, it would cause greater suffering than if they, in life here on Earth, had been driven through with a sword. ${ }^{141}$

References were made to common human experiences, occasionally juxtaposing something that could be pleasant in life with its infernal counterpart, a source of torment. In one of Pelbartus of Temesvár's sermons, a promiscuous and indulgent petty nobleman received in hell a bath of fire, tar and sulphur; a period of rest in a bed of worms; as refreshment a drink of sulphur and poison; and finally devilish music from fire-breathing instruments, burning the ears of the condemned. ${ }^{142}$

Other sources of suffering for the damned included the confusion, chaos and constant uproar of hell, where the screams of devil-torturers are accompanied by noises of torture. Invoking St. Augustine, Jan of Rokycany warned his listeners about what they might hear in hell: "But what will the devils scream? Beat, kill, bring coal, bring tar, and melt copper and lead!"143

Unbearable heat and cold and never-ending hunger and thirst are what prevailed in hell, a place marked by poverty, destruction, and senility. Gothic Church art reflected in part precisely such a vision of the place where the condemned were sent for eternal punishment. The vestibule of the abyss, out of which Christ leads Adam and Eve in the Veit Stoss altarpiece in Krakow, has a floor made of thick and broken boards, and in another representation of this scene the condemned who did not recognise the grace of liberation dwell in a place that shows similar signs of degradation.

141 Ibid., pp. 626-628.

142 Sermones pomerii fratris Pelbarti de Themeszwar "De tempore", sermon XVIII.

143 Postilla Jana Rokycany, ed. F. Šimek, vol. 2 (Prague 1929), 165 ff. 
The infernal kitchen, whose details were widely described or imagined in the arts of Western Europe, did not display its bill of fare in that part of the continent under discussion here. One exception was tar, a drink of the condemned that appeared particularly in various texts intended for popular audiences. In the Polish and Czech languages, we can detect an early connection between the words for hell (piekło, peklo) and tar (in Polish, smoła). In Czech documents from the twelfth century, the word pkelnici does not refer to the inhabitants of hell (as we might assume) but rather to smolarzy; that is, people whose work involved scorching the resin of conifers in a suitably prepared depression in the earth, which was full of flames, smoke, and which stank. There was thus an association between a smolarnia and the kind of hell that was taught in churches, and the connection between smoła and the world of evil, demons, etc., persisted in folklore.

The repertoire of bodily punishments and torture described in images of hell in the Late Middle Ages, both in paintings and in written texts, in Central and Eastern Europe is generally meagre relative to similar images in the West, both earlier and contemporary. Firewheels with the damned strung up by their teeth and great wheels with hooks tearing at the bodies of the damned are items that we read about probably only in the texts of Bohemian translations (or rather, Bohemian versions) of Visiones Georgii, ${ }^{144}$ a fantastical description of travels through the next world that emerged in fourteenth-century Avignon. In painted images of hell, present almost exclusively in scenes presenting the Final Judgment, a small role is played by instruments of torture drawn from real judicial settings. We see them in murals in Zgorzelec on the western edge of Silesia, and in Torun, which, when these frescos were painted at the end of the fourteenth century, belonged to the Teutonic State. The painter's vision of hell no doubt had an influence on the faithful's imagination. Discussing the posthumous sufferings of Konrad von Wallenrode, who was said to have been the subject of a nightmare, Dorothea of Montau offered up a conventional depiction of infernal reality, like that which we see in murals and which included a hearth with embers fuelled by demons, a blacksmith's pliers, tridents, spiked poles and other instruments used to torture the condemned soul. ${ }^{145}$ The fragmentary nature of the preserved murals on Bohemian territory (and, to a greater extent, in the Kingdom of Poland), the rarity of these motifs in murals on Hungarian

144 Jiříkovo viděnie, in Próza českého středověku, ed. J. Kolár, M. Nedvědová (Prague 1983), $216 \mathrm{ff}$.

145 Johannes Marienwerder, op. cit., p. 372. 
territory, and their often highly illegible character, all indicate that we must be careful when analysing their content. However, the preacher's vision of hell, including from Hungarian sermons from the end of the Middle Ages, in which the subject of posthumous punishment is a lively component, also does not contain the motif of sophisticated torment, and does not indicate a penchant among their authors for brutal or macabre content. In Bohemia both in pre-Hussite days and during the Hussite period, writings demonstrate restraint in this regard.

In the late Hussite period, Petr Chelčický, author of religious tracts and sermons, a harsh moralist, and indeed a true enthusiast when it came to the infernal punishments sinners deserved (he categorically rejected belief in purgatory), did not dwell on torture or the torment of the condemned. In addition, the prominent and already well-known to us Utraquist Jan of Rokycany, although he warned his faithful against "burning in hell," avoided the use of macabre tones, and he drew comparisons from everyday life. In a sermon on the parable of the rich man and Lazarus, he described the posthumous fate of the sinner who grows fond of a life of splendour: "There, in hell, his clothing will be vermin, for he will not have a garment of material, but of snakes, of frogs, of lizards, which will bite him more than [earthly] parasites and fleas." 146

The lack of impressive and fantastical visions of infernal torment in Poland, Bohemia and Hungary was not the result of ignorance about foreign texts on other-worldly visions. Preserved manuscripts of such texts in these countries (including, in Bohemia, the above-mentioned translation of Visiones Georgii) indicate that writings of this kind had penetrated Central and Eastern Europe. However, their dissipation was rather slow, which might well explain their weak influence on murals. In another work I have speculated that the limited space given to torture in visions of hell from the fourteenth and fifteenth centuries in Poland, along with their weak connection with temporal realities, can be tied to the legal realities of this country. Torture as a means of forcing testimony in court proceedings became widespread in Poland only in the fifteenth century, although it was well known earlier in other places. ${ }^{147}$ In the fifteenth century, the devil was occasionally associated with a torturer, but in the following century, the two figures were commonly joined; in the contemporary imagination, hell became a torture chamber equipped with the appropriate tools. This is only a suggestion that I have not attempted to apply to countries other than Poland,

146 Postilla Jana Rokycany, vol. 2, p. 167.

147 S. Bylina, "L’Enfer en Pologne médiévale (XIV-XV s.)," Annales. Économies, Sociétés, Civilisations (1987), No. 5, 1235 ff. 
in particular to Hussite Bohemia, where attitudes in this regard could have had entirely different and specific determinants.

Hus himself did not dodge the issue of hell in his sermons, but, as we noted above, he opposed the primitive didactics of fear. He wanted Bohemian Christians to wait for the return of Christ and the Day of Judgment with trusting and calm hope. He described the dangers of hell to his listeners with moderation; he preferred tones of warning over the use of violent rhetoric and terrifying examples. Discussing punishment in hell, he emphasised the presence of both spiritual and physical torment (burning fires, overwhelming cold). Based on Hus's sermons, hell was the place of divine punishment for those whom the Bohemian reformer and moralist viewed as having spread evil, and those against whom he was most zealous in battle. Interpreting the Parable of the Weeds from the Gospel, he declared that the devil had sown cheaters and liars with indulgences, who were defended by priests and church dignitaries, while university scholars, although they saw evil, remained silent. But harvest day was coming, when "their hands and feet will be tied by evil and they will be thrown into the outer [infernal] darkness." 148

This attitude of restraint and moderation in conveying to the faithful a vision of eternal punishment seems to be typical of the early-Hussite Praguer reformers. In a sermon in 1417, Jacob of Mies, the successor to Jan Hus at the Bethlehem Chapel in Prague, zealous theoretician and practitioner of Communion under both kinds, tried to convince the faithful that: "hell is not prepared for people, but for devils," and that only devils, and not Christians, were thrown into hell. Jacob's views were not shared by Jan Želivský, preacher to the poor residents of Prague and tribune in the revolt of July 1419, which marked the beginning of a new phase in the Hussite movement. In eternal damnation he saw the fate of both the stereotypical sinner and also that of "prelates and masters" persecuting good priests; that is, those of the Hussite persuasion. For him, the Heavenly Kingdom was the "parish of the poor," while hell was a place in which the proud and wealthy would be deprived of their comforts, honours and joys. ${ }^{149}$ However, the reality of hell did not fascinate the Praguer preacher; for him, it was secondary to the more important vision of the presence of the Anti-Christ among people and the joyous expectation of the real descent of Christ to earth.

148 Výhor z české literatury doby husitské, ed. B. Havránek, J. Hrabák, J. Daňhelka, vol. 1 (Prague 1963), p. 166.

149 Jan Želivský, Dochováná kázáni, ed. A. Molnár (Prague 1953), vol. 1, pp. 184, 195 n., $199 \mathrm{ff}$. 
It was straightforward to draw associations between the place of eternal suffering and a prison. The Polish author of Sunday sermons, Mikołaj of Błonia, even though he avoided excessive materialisation of the infernal reality, argued that it was as if the condemned spirit were "bound and kept in perpetual prison" (in carcere perpetuo). Apocryphal works, by nature open to legendary themes, and often used quite freely for comparison, identified the condemned with prisoners whom no one could free from bondage. In addition, the words of a Polish hymn on redemption for prisoners in hell give expression to a belief that infernal reality converges with earthly reality, where release from prison, and manumission from servitude, was possible. At the same time, we come upon writings with eschatological content that highlight the irreversible nature of being locked up in hell. Such beliefs appear to have something to do with popular beliefs and the popular imagination.

Efforts were made in Church didactics to draw a clear distinction between hell as a closed space and purgatory, the place of temporary punishment, from which prayer, church attendance, fasting and good deeds can free the repenting soul. Regarding the place of eternal punishment, any initiative taken by the living transpires to be ineffective. In one of his sermons, Osvaldo de Lasko assured listeners that even if every person on Earth began to pray for a single condemned person, and if a thousand masses were given in his name, if a thousand prayers were said, a thousand people fasted, and a thousand alms were given, it would not help the condemned at all. Writers of Late-Middle-Age texts on dead sinners eagerly took up the motif of other-worldly signs and voices testifying to their certain condemnation. Jan of Czarnków told a story that was no doubt repeated by word of mouth about events that came in the wake of the funeral of an evil and promiscuous bishop who enjoyed worldly pleasures. That night, in the church in which the funeral ceremony had taken place, various noises could be heard, horses hooves stomping on the floor, and calls of: "Let us dance." ${ }^{150}$ A reader of this chronicle would learn about the consequences of the undignified and overly earthly life of the Bishop of Zawisza, and about the consequences of the improper ceremony surrounding his burial, a ceremony that was more suited for a secular dignitary. However, the stories in sermons about those who had returned to Earth from hell served other goals, namely to provide laymen with a warning about the actual existence of the place of eternal punishment and the corporeal misery that goes with it. At the same time, theologians and preachers

150 Joannis de Czarnkov Chronicon Polonorum, ed. J. Szlachtowski, in Monumenta Poloniae historica, vol. 2 (Lvov 1872), p. 713. 
condemned the folk belief in the return of the dead, saying in this case that no one returns from hell.

The collective imagination was glad to locate hell in specific places, ones that were not so far away, so as to facilitate the condemned's contact with the former, earthly environment. Peregrine of Opole envisioned the entrance to hell in one of his farm's fields, in the cavity of a dried up spring. According to Jacobus de Paradiso, others heard the moans and complaints of the condemned in a nearby valley. In beliefs found in folklore, the entrance to hell was often located in uninhabited, wild places that had a bad reputation. "Piekło" (hell) as place names in Poland, and probably also in Bohemia, many of which originate from the Middle Ages, would seem to confirm the belief that the place of eternal punishment was local. Folk beliefs talk about gaps and crevasses in the earth in which local people saw devilish fires and smelled the resulting smoke.

\section{"The Third Place"}

The triumph of the idea of purgatory as a place of temporary posthumous penance, which is visible in the West from around the beginning of the thirteenth century, also came to Central and Eastern Europe, although it is difficult to say exactly when. What is certain is that in the last two centuries of the Middle Ages, the motif of purgatory was broadly present in Church teachings and in religious beliefs and practices, but also-not without certain limitations-in collective imaginations.

However, we must note that written texts from the fourteenth and fifteen centuries that address the matter of purgatory show uncertainty and indecision about what to call this place. It was only apparently simple to find a suitable equivalent for the Latin term purgatorium in the Czech očistec or the Polish czyściec, both of which refer to places of cleansing or purification. In Bohemia, the Latin purgatorium was used interchangeably with the enigmatic term limbus, or limbo; and, in addition, it took a long time for the terminology surrounding purgatory to liberate itself from its connection with hell. Jan Hus called purgatory the "third hell" (alongside the hell of the condemned and that place where the spirits of unbaptised children dwell), although he understood the peculiar situation experienced by those who suffered a transient punishment. In CzechLatin dictionaries from the fifteenth century, purgatory is identified with a kind of "pre-hell," ${ }^{151}$ or entry way into hell, which was a very late echo of earlier

151 Staročeský slovník, z. 9 (Prague 1977), p. 260. 
images. A certain Polish theologian from the fifteenth century, speaking about hell's position underground, isolated a second vault within that space; that is, purgatory, which, by locating it in an underground hell, as a separate part of hell, was thus bound to a very powerful tradition. However, I would not perceive in all of this a lack of appreciation or understanding of purgatory's role as an intermediate space in the afterlife, a place in which suffering human souls wait for liberation and salvation. In any case, this current of full and hopeful expectation appeared rather early, including in texts in which there was no shortage of fantastical motifs.

In the middle of the thirteenth century, just before Stanislaus of Szczepanów was officially canonised, the Polish Dominican Wincenty of Kielcza wrote his Żywot św. Stanisława, in which he talked about one of the Bishop's miracles, namely the resurrection of a certain knight, Piotr, who had died and been buried for several years. The saintly Bishop knew that only through Piotr's resurrection could he confirm that the village that had belonged to Piotr now belonged to the Krakow Church, and not to Piotr's relatives, who were supported by King Bolesław, who would later have Bishop Stanisław executed. We are thus able to observe the very tense events that played out in the village cemetery: the excavation of the grave, the ritual resurrection of Piotr, the Bishop taking Piotr to the King and all those assembled for the hearing, and finally Piotr's testimony to the truth that none of the living could obtain. Later, having been asked by Bishop Stanisław if, in return for his services, he would like to be paid with a few years of life on earth, Piotr responded without hesitation:

I thank you Venerable Father, but I would rather that you put me back in the grave, since I will have to dwell in purgatory for my guilt not much longer, and then later, thanks to merciful God, I will move on joyfully to the place of eternal rest. ${ }^{152}$

The words of the resurrected knight, who had already learned the secrets of posthumous existence, contain hope: why choose an uncertain earthly life, constantly threatened by sin, when penance in purgatory would soon end, and the joys of eternal reward would follow? This story supporting the cult of St. Stanisław contained essential didactic virtues; in the fifteenth century, Jan Długosz repeated the story, in an expanded form, for his chronicle.

It was with difficulty that a person comprehended and accepted the permanence and irreversibility of infernal punishment. The human imagination easily absorbed a basic vision of posthumous torment and suffering, but it forced

152 Vita S. Stanislai Episcopi Cracoviensis (Vita Maior), ed. W. Kętrzyński, in Monumenta Poloniae historica, vol. 4 (Lvov 1884), p. 264. 
instructors to put significant effort into explaining the meaning of eternal punishment. Among the faithful, knowledge of eternal punishment created the need to explain how a terrible and irreversible sentence-one that had no earthly counterpart-could be justified; it was understood that, on Earth, there were various punishments for misbehaviour; that they did not always have to be the most severe; and indeed that, under a person's own influence, they could be alleviated. But hell deprived the condemned of any hope, and it deprived the living of any possibility of intervening on their behalf.

Knowledge of purgatory led to a verdict that was less categorical, for its consequences were more measured. Moreover, the temporary suffering adequate for purgatory could be moderated, the sentence of penance could be shortened thanks to God's mercy, intercession by the saints, the prayers of the Church, of relatives, of friends of the dead, along with various other forms of human intervention. This is why the spread of Catholic instruction on the matter of purgatory, the place where temporary penance was served for small, daily sins not expiated in earthly life, opened up space for human hope. The fire of purgatory-long known as a purifying fire (ignis purgatorius) or corrective fire, but also a transitory, temporary fire-led to another, perfect reality, to a place where the saved dwelt. If it raised fears, they were not accompanied by a sense of hopelessness.

In neither pre-Hussite Bohemia nor in Poland was the motif of purgatory introduced into church painting before the sixteenth century; in any case, no clear traces of such representations have been preserved. Such a situation can be explained in part by the rarity of artistic images depicting places of posthumous punishment and reward outside of the context of the Last Judgment, which, according to Catholic eschatological doctrine, marks the close of purgatory's function. In paintings depicting the scene of the Last Judgment, the human soul received either salvation or eternal damnation. Beyond that, illustrating the reality of purgatory raises various difficulties and doubts that were unsettled, in the end, by theologians. In any case, in Western Europe we see murals representing purgatory that indicate a divergence of motifs and a lack of consistency in the ways the reality of the place of transitory punishment is depicted. For example, in southern France purgatory is illustrated either without elements of suffering (we see only a closed space inhabited by repentant souls and an angel descending with refreshment) or entirely differently, as a place filled with fire and even populated by devil-tormentors. In the latter, purgatory imitated hell, although it was in a sense milder, with smaller flames for example.

In earlier descriptions of other-worldly visions and illuminating stories collected at the beginning of the thirteenth century by Caesarius of Heisterbach, it was difficult for those who had found their way into a place of posthumous 
punishment to identify where they were; some who found themselves in purgatory thought they were in hell. At the beginning of the fifteenth century, Dorothea of Montau, having come out of a vision lasting several hours in which she had caught a glimpse of purgatory, was so taken by what she had seen that she brought herself to deliver a warning to all those who trusted too much in the possibility of penance after life: "Oh, how little they know who ask for purgatory!" 153 In the above-mentioned Bohemian version of Visiones Georgii, the hero of the work beholds the "torment of a hellish purgatory", in which the physical suffering experienced by penitents is no different than the most brutal tortures experienced in hell as described in the same work. In Late Middle-Ages Poland, we do not see such drastic forms of purgatory as an inferno, although Church teachings of the faithful emphasised the severity of purgatorial suffering. In Hungarian sermons, the level of invention shown in depicting the torment of purgatory was no doubt lower than in their visions of hell. We see assurances of the harshness of penance more often than descriptions of the suffering of penitential souls. Nonetheless, Osvaldo de Lasko quotes from the telling exemplum, known from patristics, according to which a certain newly selected abbot, on a stroll one evening along the water, heard plaintive cries from its depths. Having established that they were the voice of his friend and predecessor suffering a purgatorial punishment after death, he noted somewhat scornfully: "Your punishment is not great, as you are cooling yourself in the water." To this he heard the response: "Take the iron candlestick from the church and put it in this water, and you will quickly see it melting like wax in a fire." ${ }^{154}$ This is a moving story even if it contains no detailed description of torment.

In Church teachings, the harsh purgatory, one that threatened great torment, also showed another, more mild facet. A place of posthumous punishment, it was also a place of mercy that was not accessible to unreformed, obdurate sinners. People familiarised themselves with the prospect of purgatory, which was perhaps influenced by the notion that a visit to purgatory was common, if not practically universal. Present in sermons of the Late Middle Ages was a vision of purgatory as a thickly populated place of mass penance. Occasionally, ideas that went too far had to be corrected: Osvaldus de Lasko opposed the view according to which even the saintly Hungarian King Stephen had been unable to avoid purgatorial penance.

153 Die Akten des Kanonisationsprozesses Dorotheas von Montau, pp. 30-31.

154 Osvaldus de Lasko, Sermones de sanctis [...], (Hagenau 1497), k. 399r. 
The idea of purgatory, independent of how people imagined this "third place" of the afterlife, was met with opposition from representatives of radical currents in the Bohemian reform movement. We can pass over the intra-Hussite doctrinal conflicts over purgatory and the subtleties of the various positions taken, but we can say that the Taborites absolutely rejected purgatory, and that the supporters of moderate positions questioned only the forms of intercession on behalf of souls, common in the Church, especially those from priests that could draw material benefit.

The Chiliasts within the Taborite movement, by virtue of their internal logic, rejected the possibility of accepting a space between heaven and hell. Enthusiasts of the prophecy that Jesus would once again descend to earth anticipated this event as the beginning of an immediate reward for the chosen ones and terrible punishment for the rest of sinful humanity, especially including their ideological opponents. In the ethics of early Taboritism, light and everyday sins, ones which would qualify a person to serve a moderate punishment, lost their significance, as there were no longer "moderately good" and "moderately bad" people; there was only God's chosen people and intransigent sinners. The first would reign triumphant alongside Christ, and the second faced eternal suffering in hell.

Later, Taborite theologians negated purgatory based on a lack of convincing testimony from the Holy Scriptures. They interpreted relevant fragments from the New Testament differently than Catholics did, including the words of St. Paul on the possibility of salvation "yet so as by fire" (1 Corinthians 3:11-15). They thus argued that no purgatorial fire existed, nor did any other posthumous torment limited in time. While Taborite theologians, debating with Utraquists (and indirectly with the Catholics) drew their argumentation from the Bible, less learned preachers and propagandists tried to use other methods to reach the mentality and imagination of their listeners. One such method involved ridiculing, and thus discrediting, Catholic beliefs, objects of worship, practices and religious customs. In this regard, untranslatable word games opened up possibilities. According to a late text by Jan of Príbrami, the Taborites called purgatory (očistec) ošistec, which in Czech is easily associated with fraud (understood as the clergy's treatment of the faithful). They mocked the Latin word purgatorium with the expression purgáč, which refers to a means of purging the stomach. Such a collection of words was easily embedded in an individual's memory and then made their own way into the collective memory. With the end of Taboritism, scorn for and ideological disbelief in purgatory died out in Bohemia. However, scepticism remained along with a basic reserve towards excessive trust among some of the faithful in the possibility of posthumous penance. We read the following in the 
Czech version of the famous poem, translated from the Latin, "Master Polikarp's Dialog with Death":

Neklad' také své náděje

$\mathrm{V}$ očistci na onom světě neb očistec nejistec naplňuje kněžský měšec
Do not take hope in purgatory in that world for purgatory is an uncertain thing and it fills the priestly purse

a "Rozmlouvání člověka se smrtí," in Veršované skladby doby husitské, ed. F. Svejkovský (Prague 1963), p. 79.

Nevertheless, clergymen in the Utraquist Church sought a Christian purity of faith in purgatory, one that was free of folk superstitions.

However, let us return to the popular imagination of the "third place" of the afterlife in Catholic countries. Purgatory's openness to the living, the inclusion of the faithful in Church prayer directed at penitent souls, and the partial dependence of those souls on the religious activity of the faithful, can all be understood as compensation for the fact that hell was absolutely closed, from which it was forbidden to have any outside contact. But in mass belief and the mass imagination, purgatory was open wider than theologians wanted to see it. Not without the influence of preachers, human imagination filled the Earth with purgatorial phenomena that appeared among the living and maintained age-old bonds with them. We are not talking here about the kind of souls, discussed in a previous chapter, that were derived from pre-Christian beliefs, and which were wandering the earth in physical form, threatening the living and demanding satisfaction of their material needs, but rather about apparitions arriving from the afterlife to achieve goals that were consistent with Church didactics: confirmation of the existence of purgatory, to warn sinners to improve their lives, and to convince the living of the significance of various forms of intercession on behalf of the dead. The problem was that it was quite easy for some preachers and authors of collected sermons to meet the needs of collective imagination, a fact that did not escape the attention of theologians and critics of the state of religious life, who wanted to achieve purity of faith and imagination among laymen. Most ominously, it did not escape the attention of the above-mentioned Taborite theologians. With scorn and indignation, Mikuláš of Pelhřimova, one of their leading representatives, cited stories about penitent souls that played a role in Catholic sermons and that originated, Mikuláš claimed, "from the postils of greedy priests." He thus knew the story about a soul trapped in a block of ice, whose cries for help were heard by Bishop Teodolus, who was considering winter fishing. Thanks to thirty masses performed by the saintly bishop, the block of 
ice thawed and the penitent soul was released. ${ }^{155} \mathrm{He}$ also heard about the various places from which the moans and complaints of penitents in purgatory originated.

The purgatorial apparitions known in Late-Middle-Ages Poland included model arrivals from the "third place" of the Christian afterlife. Thanks to John of Komorów, author of the chronicle cited above, we learn about a certain brother Cherubin, a Bernardine from Poznan, whose soul occasionally wandered the Earth. Suffering a posthumous punishment in purgatory for petty but unforgiven transgressions, brother Cherubin was a mild ghost; he frightened no one and caused no one harm. He appeared on Earth in his own image, although he occasionally also took the form of a dog walking at the side of a woman charged with the task of returning a debt for wine at an auberge. Through some pious women, he turned to his former confreres, Bernadines, with a request that they perform a mass in his name. Concerned for the liberation of his own soul from purgatory, brother Cherubin did not forget about the welfare of the monastic community, in particular that its members had to maintain discipline, so he thus reminded his brothers that they should not leave the monastery unnecessarily. ${ }^{156}$ The didactic significance of the story about brother Cherubin, who in the end left purgatory and gained salvation, is all too obvious and correct; the story showed the role played by atonement for a person's transgressions and the importance of masses and prayer in the intention of the soul dwelling in purgatory. This apparition from the afterlife, attempting to lead his monastic brothers along the correct path, achieved an uplifting objective. Brother Cherubin was part of the mild version of purgatory, in which penitent souls suffer, but thanks to help from the living, their suffering ends relatively quickly. Here is the question: was such a vision of purgatory more prominent in the faithful's imagination than the vision of purgatory as a quasi-hell? Widespread efforts in the fifteenth century to gain indulgences covering a few decades or up to several centuries of posthumous penance, the call for prayers to liberate souls from suffering up until the Last Judgment, indicate without a doubt the presence of that version of purgatory tied to severe and long-term punishment. Having said that, the awareness that this suffering-even the longest and most painful-would someday end, turned purgatory into an instrument of hope, something that was not without significance in human thinking about the future. In Bohemia, where Hussitism

155 Confessio Taboritarum, eds. A. Molnár, R. Cegna (Rome 1983), p. 191.

156 Memoriale Ordinis Fratrum Minorum a fr. Joanne de Komorowo compilatum, eds. A. Lorkiewicz, X. Liske, in Monumenta Poloniae historica, vol. 5 (Lvov 1888), p. 276. 
reinvigorated Christianity and gave it a new enthusiasm, but where it also sowed doubts, Jan of Rokycany, through his faith, restored hope: "If there were no purgatory, God would then be neither just nor merciful." It eased fears about eternal punishment, which did not become an obsession of the inhabitants of Central and Eastern Europe. 



\section{Final Comments}

In this book I have discussed, albeit in abbreviated form, people who represented various levels of religious knowledge and culture. The focus has frequently been on people about whom the sources from the period under discussion here are silent, or to whom the sources make only passing or generalised references. Those involved here are people who, despite their troubles and misfortune, did not take part in pilgrimages to make pleas or give thanks, because they lacked the courage to set out on a journey to unknown and distant places; people who were never invited as witnesses at diocesan visitations, because they were too simple and nothing of significance was expected to be heard from them; people who made up the "silent majority" of the faithful, whose behaviour and statements were unrecognised and unappreciated; people embedded in the silent masses who nonetheless knew that they were Christians. This was a feeling shared by, for example, the Praguer followers of Jan Milíc of Kroměŕǐze, who were deeply affected by the content of Christianity, and by the simplest of Bohemians, Poles and Hungarians who had to struggle to remember the words to the Lord's Prayer. There was a gap between one and the other in terms of their level of religious consciousness, just as there was a gap, not always as large but also deep, between residents of big cities and members of the significant religious brotherhoods on the one hand, who often had close contact with the liturgy and the Word of God, and on the other hand the inhabitants of towns and villages located somewhere far from the diocesan church. However, regardless of the message conveyed in churches, everyone drew from one tradition or another, occasionally a common tradition despite social differences, occasionally distinct as the result of many factors.

At the end of the Middle Ages, tradition and custom were still essential features of culture; they were basic to folk culture and very much present at all levels. Simple folk invoked age-old customs, ab antiquo tempore, as an extremely important justification for all sorts of conditions. Rural Bohemians invoked these customs in support of demands made to the visiting archdeacon regarding neglect in the church life of dioceses. Educated people also recognised and appreciated customs, in particular those who were called upon to draw distinctions between good and bad customs. Let us recall that in his treatise, the Moravian Jan of Holešov categorically separated good and true Christian Christmas Eve customs from the bad and erroneous customs that people also practiced. Diocesan statutes do not indicate an interest in certain folk customs 
and ceremonies, but they condemned others as following "the pagan example." The Bohemian author Stefan of Roudnice, writing at a time when Corpus Christi processions did not yet go out onto city streets, asked many questions about appropriate and inappropriate practices surrounding divine worship, including whether a procession through, and a blessing of, market squares (as happened during important holidays in Jaroměr) was permissible. His conclusion was that such ceremonies could be celebrated, especially because they had already become customary. However, in the eyes of this theologian, references to custom could not justify the springtime ritual of circling the fields with a cross, which were performed without the participation of a priest and were thus condemned, as opposed to the spring rogationes processions, which were organised by the local diocesan clergy, even though the latter ritual contained a certain amount of uncertain beliefs whose roots were in folklore. The legacy of age-old folklore, handled by Church representatives reluctantly or with embarrassment, brought confusion to established concepts and deprived village inhabitants of the ethical superiority over burghers that was often ascribed to them. Jan of Rokycany, who argued in front of his bourgeois listeners that, "had they remained peasants and ploughmen like their mothers and fathers, their salvation would be much easier," ${ }^{\prime 57}$ was well aware of the superstitions and objectionable practices of village inhabitants, even while villagers were for him an object of secondary interest.

The persistence of customs, both those of ancient origin and those integrated by the faithful within the Church, did not go unchallenged. The first group of customs (if they were not integrated, neutralised or simply went unnoticed by the Church) faced pressures applied by bishops, preachers and confessors who were battling what they regarded as a threat to the pure faith and divine worship. The second group, of course only in certain circumstances, faced the hostility of radical ideologues in religious movements that rejected the Roman Catholic Church along with its traditions and rituals. The Hussite cedat consuetudo (let custom yield), declared on the eve of the Hussite revolution by the Praguer tribune Jan Želivský, ${ }^{158}$ enjoyed an unquestioned but temporary triumph. Retreating somewhat in time, let me cite an example which admittedly refers to the margins of religious life, but which is nonetheless telling. At the end of the fourteenth

157 Postilla Jana Rokycany, vol. 2, p. 179.

158 See A. Molnár, "Aktywność ludu w ruchu reformatorskim. Świadectwo kazań husyckich," in Kultura elitarna a kultura masowa w Polsce poznego średniowiecza, ed. B. Geremek (Wrocław 1978), p. 89. 
century, certain followers of the Waldensian movement in Western Pomerania and Brandenburg, which was a community of heretics with simple rituals, were not able to give up some of the Catholic customs known to them: contrary to the teachings of wandering missionaries, they decorated Easter palms and showed no contempt for holy water. ${ }^{159}$ Or was this perhaps simply their way of hiding their true faith environment around them?

Stubborn though they were to the efforts of preachers, and despite threats of punishment formulated by Church agents called to this task, folk customs and rituals succumbed to the destructive influence of time, even though they did not disappear altogether from folk culture. The words tied to rituals and songs were distorted (not always through the pen of clerics who were unskilled in their description), and magical formulas often preserved their old roots while they were overgrown with new expressions and phrases.

More than folk beliefs and rituals, what has been important in this book were the traditional attitudes and imagination present in the religiousness of the Christian masses. I expressed the view that we need not tie the basis of these attitudes to magical practices alone, whether ancient or "Christianised," or with attempts to influence nature with the help of consecrated objects or with words and expressions with Christian content. This is because what is involved here is an undoubtedly more important phenomenon, namely the circumscription of a person's contact with God, and with the saints, above all by temporal matters. Such a tendency was no doubt extremely powerful in folk religion, though not so powerful as to entirely dominate that religion. After all, we can neither forget the factually universal concern for salvation, nor minimalise the significance of religious feeling. As it seems that appeals made to God (along with statements of thanksgiving, which are more weakly documented in the sources) did not need to contradict any kind of "contract" concluded concerning a desire to be healed or liberated from oppression, etc., we do not need to divide people participating in pilgrimages into two categories: those who prayed "as a Christian" and those who treated prayer, along with the oath associated with prayer, as something resembling a spell. One of the foundational goals of folk religion was to integrate these two factors. It also cannot be claimed that shepherds, who according to Stefan of Roudnice would give a kind of "blessing" to their herd to protect it against attacks from wolves and bears, rejected the prayers encouraged by the Church. Instead of mentioning other such examples, let me recall the

159 Quellen zur Ketzergeschichte Brandenburgs und Pommerns, ed. D. Kurze (BerlinNew York 1975), p. 139. 
"confession" of the superstitious person who, according to his own testimony, said that when he uttered magical formulas and used amulets, he did it "in the name of Jesus," which meant that he had not sinned. Even if that text (cited above) had been invented by the author, it surely confirms that folk religion was not something strange and foreign to him.

In presenting in this book the results of research conducted in certain undoubtedly crucial aspects of folk religion in Central and Eastern Europe in the fourteenth and fifteenth centuries, I occasionally directed the reader's attention to the similarities and differences with the reality in Western Europe. Occasionally, those differences can be found in details to which I will not return here. However, the fact is that we can notice them at the juncture of Christianity and traditional rituals located, in the context of Poland and Bohemia, in the annual cycle of the old Slavic calendar. In the case of collective devotion, the universal nature of many important phenomena was determined, of course, by a common affiliation with Western Christianity. But here, too, themes emerged that were perhaps not so much autonomous as original through their particular emphasis on certain issues, an example being laymen's typically Bohemian desire (although there were reflections of this in other territories) to take the Eucharist often. Certain aspects of the Marian devotion were original, for example the deeply emotional maternal cult-typical of Polish lands-surrounding the Most Blessed Virgin Mary.

Regarding various areas of religion, we can speak of a rather distinct imagination and eschatological sensitivity in the countries under discussion, where it seemed that the prospect of posthumous punishment caused less fear than was the case in the West. I also expressed the view that, in this part of Europe, fear of eternal condemnation did not occupy a particular place in religious didactics. Comprehensive research in Polish, Bohemian and Hungarian sermons and preaching, as well as the exempla at work in sermon collections, would allow us to verify the suggestion, based on sources, that the presence of the devil in Church instruction was weaker here than in the West, and that as a consequence the peoples living in Central and Eastern Europe lacked an obsession with Satanism. Of course, such a view does not involve a vision of the Anti-Christ, expected or already present among the population, an elite vision in the Bohemian reform movement in the fourteenth century, but also a vision that had a broad reach in the early phase of Hussitism.

Writing about the Late Middle Ages in Central and Eastern Europe, scholars often emphasise-although today it sounds banal-the deeply syncretic nature of Christianity in this part of the continent, of the intensive coexistence of Christianity with local cultures that lasted for a shorter period of time than was 
the case in Western Europe. The phenomenon then emerges, and indeed takes on prominence, of the relative "freshness" of archaic traditions (beliefs, imagery and attitudes), one that encourages us to take a new look at the effects of the encounter between two cultures and two worldview systems on the territories of the "younger Europe." 



\section{Bibliographic Information}

From the recent secondary literature on the subject, see above all of the works of J. Kłoczowski addressing the issues raised in this book against the broadest background, including the synthetic overviews: Młodsza Europa. Europa Środkowo-Wschodnia w kręu cywilizacji chrześcijańskiej średniowiecza (Warsaw 2003). See also the following collections: Christianity in East Central Europe, vol. 2: Late Middle Ages, ed. J. Kłoczowski (Lublin 1999); Historia Europy ŚrodkowoWschodniej, ed. J. Kłoczowski (Lublin 2000) (see also the French version: Paris 2004, PUF, Nouvelle Clio); Europa Środkowo-Wschodnia od X do XVII w., eds. K. Baczkowski, J. Smołucha (Krakow 2005), which includes works by J. Kłoczowski, S. Bylina, and M. Nodla.

For more on matters related to religious culture, see the following recent works, including the collections: Ecclesia et civitas. Kościót $i$ życie religijne w mieście średniowiecznym, eds. H. Manikowska, H. Zaremska (Warsaw 2002), particularly articles by H. Manikowska and Z. Hledíkova; Animarum cultura. Studia nad kultura religijna na ziemiach polskich $w$ średniowieczu, vol. 1: Struktury kościelno-publiczne, eds. H. Manikowska, W. Brojer (Warsaw 2008), particularly articles by H. Manikowska, S. Bylina, and K. Ożoga. More recent works develop, among other issues, the issue of sacral space.

For more on the religiousness of Bohemian society in the pre-Hussite era, see F. Šmahel, Husitská revoluce, vol. 2: Kořeny české reformacje (Prague 1993), chapter 5; regarding the religious situation in Bohemia at the end of the Hussite era and beyond, see J. Macek's sweeping monograph, Víra o zbožnost jagellonského véku (Prague 2001).

Religious matters on the territories of the Teutonic States are covered by S. Kwiatkowski, Klimat religijny $w$ diecezji pomezańskiej u schyłku XIV $i w$ pierwszych dziesięcioleciach XV w. (Torun 1990) and A. Radzimiński, Koścół w państwie zakonu krzyżackiego w Prusach 1243-1525 (Malbork 2000).

Hungarian issues are a topic in G. Klaniczay's work The Uses of Supernatural Power. The Transformation of Popular Religion in Medieval and Early Modern Europe (Princeton 1990).

For more on the parish network on Polish territories, see E. Wiśniowski, Parafie $w$ średniowiecznej Polsce. Struktura i funkcje społezcne (Lublin 2004) (expanded version compared to the 1964 text). An overview of scholarship on various countries in Central and Eastern Europe can be found in Pfarreien im Mittelalter: Deutschland, Polen, Tschechien und Ungarn im Vergleich, ed. N. Kruppa (Göttingen 2008). 
The Polish people and their participation in religious devotion are the topic of several works: I. Skierska, Obowiązek mszalny w średniowiecznej Polsce (Warsaw 2003); S. Bylina, Chrystianizacja wsi polskiej u schyłku średniowiecza (Warsaw 2002).

For more on the basic catechism of the faithful in parishes, see my article in the above-cited Christianity in East Central Europe (2). See also the collection Nauczanie w dawnych wiekach, eds. W. Iwańczak, K. Bracha (Kielce 1997). J. Kłoczowski's work showed more clearly than other cited works the role of the mendicant orders in serving the pastoral needs of the faithful (mainly, however, in urban areas).

Results of research on preaching in Poland are presented in K. Bracha's comprehensive monograph Nauczanie kaznodziejskie w Polsce późnego średniowiecza. "Sermones dominicales et festivals" $w$ tzw. kolekcji Piotra $z$ Miłosławia (Kielce 2007). Z. Uhliř focused research on preaching in Bohemia, particularly in his article in volume 7 of the Almanach Historyczny from 2007. E. Madas devoted many publications to preaching in Hungary in the Late Middle Ages.

See A. Karłowska-Kamzowa's article in the collection Literatura i kultura późnego średniowiecza w Polsce, ed. T. Michałowska (Warsaw 1993) on instructional images in Poland in the Late Middle Ages.

For general treatments of collective devotion, see my study "Wierzenia i pobożność" in Kultura Polski średniowiecznej XIV-XV w., ed. B. Geremek (Warsaw 1997) and, with reference to Central and Eastern Europe, the collection Człowiek $w$ społeczeństwie średniowiecznym, ed. R. Michałowski et al. (Warsaw 1997). See also the collection of articles in Zbožnost středověku, ed. M. Nodl (Prague 2007). On currents of devotion related to devotio moderna in Western Europe, see the collection Die "Neue Frömmigkeit" in Europa Spätmittelalter, eds. M. Derwich, M. Staub (Göttingen 2004), which contain studies on Bohemia, Silesia, Poland and Hungary. See also my article "Nurty odnowy wewnętrznej a problem częstej komunii w Europe Środkowej w XIV-XV w.", in Scriptura custos memoria. Prace historyczne, ed. D. Zydorek (Poznan 2001).

Among the many works devoted to the issue of saint worship in Central and Eastern Europe, see the collection of studies Svätec a jeho funkcia $v$ spoločnosti, eds. R. Kožiak, J. Nemeš, vol. 1 (Bratislava 2006). See also another collection of studies: Fonctions sociales et politique du culte des saints dans les sociétés de rite grec et latin au Moyen Âge et à lépoque moderne, ed. M. Derwich (Wrocław 1999), which includes an article by H. Manikowska on the worship of the patron saints of cities. For the fruitful results of Hungarian scholarship, see G. Klaniczay, E. Madas, "La Hongrie" in Hagiographies, ed. G. Philippart, vol. 2 (Brepols-Turnhout 1996). 
The phenomenon of relic worship in Poland against a broader backdrop is examined in M. Starnawska, Świętych życie po życiu. Relikwie w kulturze religijnej na ziemiach polskich $w$ średniowieczu (Warsaw 2008). For more on Hungary, see S. Andrić, The Miracles of St. John Capistran (Budapest-New York 2000).

On the matter of relic worship of the wood of the Holy Cross (including on Polish territory), see the comprehensive monograph by L. Wojciechowski, Drzewo przenajszlachetniejsze. Problematyka Drzewa Krzyża w chrześcijaństwie zachodnim (IV-połowa XVII wieku). Od legend do kontrowersji wyznaniowych i piśmiennictwa specjalistycznego (Lublin 2003).

Among the more recent works, see in particular the collections: Peregrinationes. Pielgrzymki w kulturze dawnej Europy, eds. H. Manikowska, H. Zaremska (Warsaw 1995); Wallfahrten in der europäischen Kultur, eds. D. Doležal, H. Kühne (Frankfurt am Main 2006); Wallfahrt und Reformation - Pout' a reformace, ed. J. Hrdina, H. Kühne, T. Z. Müller (Frankfurt am Main 2007).

For more on Church attitudes towards traditional culture, superstitions, etc., see the collection of studies S. Bylina, Kultura ludowa Polski i Słowiańszczyzny średniowiecznej (Warsaw-Łowicz 1999). This matter is also a topic of research by K. Bracha, particularly in his comprehensive monograph Teolog, diabet $i$ zabobony. Świadectwo traktatu Mikołaja z Jawora "De superstitionibus" (Warsaw 1999). See also M. Olszewski, Świat zabobonów w średniowieczu. Studium kazania "O zabobonach" Stanisława ze Skarbimierza (Warsaw 2002). On annual rites, see B. Wojciechowska, Od godów do świętej Łucji. Obrzędy doroczne w Polsce późnego średniowiecza (Kielce 2000).

The scholarship on local pilgrimage cults found in A. Witkowska's monograph Kulty pątnicze piętnastowiecznego Krakowa. Z badań nad miejską religijna (Lublin 1984) is still of fundamental significance.

On the vitality of folk tradition in late medieval Bohemia, see F. Šmahel, "Silnější než víra: magia, pověry a kouzla husitského věku," Sbornik vlastivědnych praci z Podblanicka 30 (1990), No. 2. See also J. Macek, Jagellonský věk v českých zemích (1471-1526), vol. 4: Venkovský lid. Národností otázka (Prague 1999), chapter "Pověry Magie."

Attitudes towards death are a topic of H. Zaremska, "Człowiek wobec śmierci. Wyobrażenia i rytuały," in Kultura Polski średniowiecznej XIV-XV w., ed. B. Geremek (Warsaw 1997). On Bohemia in the Late Middle Ages, see Pozdné středověké testamenty v českých zemích, eds. K. Jíšova, E. Doležalova (Prague 2006).

On imagery of the afterlife, beyond my earlier monograph Człowiek i zaświaty. Wizje kar pośmiertnych $w$ Polsce średniowiecznej (Warsaw 1992), see the study "Wyobraźnia eschatologiczna," in Kultura Polski średniowiecznej XIV-XV, ed. 
B. Geremek (Warsaw 1997). On eschatology in Hussite times in Bohemia, see F. Šmahel, "Das purgatorium sompniatum in der hussitischen Topographie des Jenseits," in Eschatologie und Husitismus, eds. A. Patschovsky, F. Šmahel (Prague 1996). 


\section{Index}

A

Adam (biblical) 145

Agata, mother of Dorothea of Montau 44

Albertus, Magnus 135

Anne, Saint 48

Apollonia, Saint 77

Aquinas, Thomas 135

Arnold, Klaus 133

Arnošt of Pardubice 23, 62, 69

Augustine, Saint 61, 71

B

Banaszkiewicz, Jacek 106

Barbara, Saint 48, 74, 80

Belcarzowa, Elżbieta 129

Benedykt, Hesse 30

Bernard of Clairvaux, Saint 78, 137

Bernardino, of Siena 76

Bielowski, August 105

Binz, Louis 20

Biskup, Marian 28

Bognár, András 121, 136, 138

Bogumilus 103

Böhm, Hans 113

Bolesław II the Bold 105

Bölle, Kornél 43, 78

Bonaventure, Saint 135

Bracha, Krzysztof 94, 166, 167

Brückner, Aleksander 53, 92

Bridget, Saint 73

Budzyk, Kazimierz 53

Bylina, Stanisław 16, 147, 165-167, 170

C

Cegna, Romolo 73, 156

Caesarius of Heisterbach 132, 152
Charles IV (House of

Luxembourg) 8, 14, 50, 51

Chelčický, Petr 147

Chmielowska, Bożena 85, 128

Chodyński, Zenon 22

Corvinus, Matthias 62, 70

Ćwikliński, Ludwik 42

D

Daňhelka, Jiří 148

Długosz, Jan 25, 56, 69, 71, 105, 117, 151

Dobrowolski, Paweł 14

Dola, Kazimierz 46, 75

Dorothea, Saint 139

Dorothea of Montau 41-44, 47, 56, $64,77,79,80,137,144,146,153$

Doskocil, Karel 110

Dygo, Marian 72

E

Emeric, Saint 74

Emler, Josef 132

Erben, Karl J. 28, 93

Eschenloer, Peter 24

Eve (biblical) 145

F

Fasseau, Arsenio 89

Ferrer, Wincenty 14

Fijałek, Jan 69, 110

Florian, Saint 77, 107

Fügedi, Eric 18

G

Geremek, Bronisław 117, 131, 160, 166-168

Gerson, Jean 47 
Gertrude of Helfta, Saint 127

Granzin, Sivert 130

Gregory XI (Pierre Roger de

Beaufort) 63

Grzegorz of Lubrańca 51

$\mathbf{H}$

Hasištejnský, Bohuslav of

Lobkovic 57, 58

Hanzlik, a baker from Vimperk 120

Havránek, Bohuslav 148

Hedwig of Silesia, Saint 45, 48, 74

Helcel, Antoni 26

Helwigis, from Gdańsk 79

Henry the Bearded 74

Henryk of Hradca 120

Herold, Vilém 99

Hilarius of Litoměřice 107

Hlaváček, Ivan 19

Hledíková, Zdeňka 19, 106,

111,165

Holtzmann, Robert 105

Hrabák, Josef 148

Hus, John 106, 112

J

Jacek (Hyacinth of Poland), Saint 42

Jadwiga (Queen of

Poland) 43, 50, 51

Jacob of Mies 148

Jacobus de Paradiso 62, 137, 150

Jagiełło, Władysław 43, 75

James (archdeacon of Liège) 26

Jan of Czarnków 149

Jan of Holešov 89, 90, 159

Jan of Jenštejn 69

Jerome of Prague 75

John of Capistrano 41-43, 45, 47,

$74,76,78-81$

John of Komorów 113, 114, 156

Jan z Př́ibrami 154

Jan of Rokycany 32, 33, 40, 49, 53,

$54,57,86,104,145,147,157,160$
Janko of Wirsberg 113

Janowicz de, Paul 19, 32

Jastrzębiec, Wojciech 142

Jedlicki, Marian Z. 105

Jelicz, Antonina 53

Johlín z Vodňan $32,49,50,54$, 57,100

Joseph (of Nazareth), Saint 67

Judas Iscariot 123

K

Kadlec, Jaroslav 106

Karłowska-Kamzowa, Alicja 30, 66, 166

Karwot, Edward 84

Katarzyna, widow from

Liebenstadt 42

Kazimierczyk, Stanisław 56

Kętrzyński, Wojciech 56,151

Kiersnowski, Ryszard 70

Klaniczay, Gábor 41, 76, 165, 166

Kłoczowski, Jerzy 8, 13, 17, 86, 87, 89, 165, 166

Knapp, Eva 77

Kolár, J. 146

Konrad von Wallenrode 144, 146

Konrad von Waldhausen 23, 52, 57, 143

Kowalczyk, Maria 69

Krollmann, Christian 25

Kurze, Dietrich 161

L

Ladislaus, Saint 70, 74, 138

Levárdy, Ferenc 121, 136, 138

Librowski, Stanisław 98

Liske, Ksawery 114, 156

Lorkiewicz, Antoni 114, 156

Loserth, Johannes 119

Ludmila, Saint 74

Ludolf von Sagan 119

Louis of Anjou 74

Lazarus (biblical) 147 
Łowmiański, Henryk 13

Lucy, Saint 111

Luke, Saint 99

M

Macek, Josef 14, 33, 58, 165, 167

Matthew of Janow 62-64, 108, 109

Maciszewska, Małgorzata 107

Margaret of Hungary 81

Małgorzata, from Liebenstadt 42

Manikowska, Halina 107, 165-167

Marienwerder, Johannes 74, 144, 146

Mary Magdalene (biblical) 96, 114,120

Matthew of Kraków 29, 45, 62, 64

Medard, Saint 77

Meyer, Arnold O. 24

Michael, Saint 127

Michał, tailor from Płock 58

Michałowska, Teresa 66, 166

Milíć, Jan 24, 62, 63, 85, 98, 159

Mikołai, Rej 53

Mikołaj of Błonia 49, 149

Mikołaja z Jawora 94, 167

Mikuláš z Pelhřimova 155

Molnár, Amedeo 63, 73, 148, 156,160

Mráz, Milan 99

Mroczko, Teresa 80

Myslata, the shepherd 132

$\mathbf{N}$

Nanker, Bishop 40, 48, 142

Nedvědová, M. 146

Němec, Igor 127

Neplach, Jan 132

Nováková, Julie 110

Nowak, Peter, Bishop of

Wrocław 29

Nowak, Zenon H. 28, 29, 65, 169
O

Odložilik, Otakar 63, 108

Oldřich z Rožmberk 55

Opolczyk, Władysław 69

Osvaldo de, Lasko 24, 53, 144, 149,153

\section{$\mathbf{P}$}

Patschovsky, Alexander 49, 55, 168

Pavel, Žídek 118, 124

Paul, Saint 111

Pelbartus of Temesvár 24, 138, 139, 145

Peregrine of Opole 144, 150

Perlbach, Max 106

Petř́k, resident of Prague 78

Peter, Saint 97, 112, 127

Piotr, knight 151

Pippidi, Andrei 129

Pirożyńska, Czesława 135

Porębski, Stanisław A. 137

Potkowski, Edward 132

Prandota, Jan 78, 80

Procopius, Saint 74, 75

Przeździecki, Aleksander 106

$\mathbf{R}$

Rapp, Francis 47

Rechowicz, Marian 43

Reinbern, Bishop of Kolberg 105

Řičan, Rudolf 32, 49, 100

Roch, Saint 77

Rudolf von Rüdesheim 45

Rudolf, Cistercian from

Rudy 84, 87, 90

Rzepka, Wojciech R. 45

S

Sawicki, Jakub 27, 40, 89

Schmitt, Jean-Claude 122

Sebastian, Saint 77

Seńko, Władysław 29, 45

Sigismund, Saint 74, 75 
Stachnik, Richard 41

Stanisław of Skarbimierz 5, 6, 43,

$62,63,85,91,93,101,128,129$, $138-140,142,167$

Stanislaus of Szczepanów, Saint 74, 151

Stephen, Saint 74, 75, 153

Stefan of Roudnice 92, 160, 161

Sulpicius, Severus 91

Svejkovský, František 155

Szafrański, Adam L. 29, 45

Szlachtowski, Jan 149

$\check{S}$

Šimek, František 33, 53, 57, 143, 145

Šmahel, František 14, 78, 98, 120, $124,165,167,168$

Świnka, Jakub 26

$\mathrm{T}$

Teodolus, Bishop 155

Thietmar of Merseburg 105

Tomáš Štítný ze Štítného 28, 62, 93

Töppen, Max 74, 144

Toussaert, Jacques 15

Tüskés, Gábor 77

U

Ulanowski, Bolesław 21

Ulewicz, Tadeusz 110

Urbanek, Rudolf 118, 125

V

Valentine, Saint 77
Veit, Stoss 145

Veles (mythology) 84

Vincent, Saint 77, 119

Vitus, Saint 50, 74

Vojtěch, Saint 74

Vovelle, Michel 126

Vrtel-Wierczyński, Stanisław 121, 141

W

Wacław, Bishop of Wrocław 27

Wacław, the bailiff 120

Wenceslaus, Saint 39, 58, 74-76

Wenceslaus IV 8

Wiesiołowski, Jacek 86

Wincenty of Kielcza 151

Winter, Zikmund 33, 37, 55, 120

Witkowska, Aleksandra 47, 108

Władysław of Gielniów 45

Wolfgang, Saint 107

Woronczak, Jerzy 96

Wydra, Wiesław 45

$\mathbf{Z}$

Zahajkiewicz, Marek T. 49, 54

Zaremska, Hanna 68, 107, 117, 125, $131,165,167$

Zawadzki, Roman M. 85, 138

Zawisza, Bishop (of

Kurozwęcki) 149

Zeleny, Rostislav 26, 37, 85, 92

Želivský, Jan 148, 160

Zíbrt, Čeněk 96, 113

Ziesemer, Walther 80 


\section{Polish Studies - Transdisciplinary Perspectives \\ Edited by Krzysztof Zajas and Jarosław Fazan}

Vol. 1 Artur Płaczkiewicz: Miron Białoszewski: Radical Quest beyond Dualisms. 2012.

Vol. 2 Kinga Kosmala: Ryszard Kapuściński: Reportage and Ethics or Fading Tyranny of the Narrative. 2012.

Vol. 3 Michał Nowosielski: Polish Organisations in Germany. Their Present Status and Needs. 2012.

Vol. 4 Krzysztof Zajas: Absent Culture. The Case of Polish Livonia. 2013.

Vol. 5 Magdalena Sitarz: Literature as a Medium for Memory. The Universe of Sholem Asch's Novels. 2013.

Vol. 6 Barbara Przybyszewska-Jarmińska / Lech Sokół (eds.): Poland and Artistic Culture of Western Europe. 14th-20th Century. 2014.

Vol. 7 Katarzyna Fazan / Anna Róża Burzyńska / Marta Bryś (eds.): Tadeusz Kantor Today. Meta-morphoses of Death, Memory and Presence. Translated by Anda MacBride. 2014.

Vol. 8 Andrzej Hejmej: Music in Literature. Perspectives of Interdisciplinary Comparative Literature. Translated by Lindsay Davidson. 2014.

Vol. 9 Grzegorz Niziołek: Warlikowski: Extra Ecclesiam. Translated by Soren Gauger. 2015.

Vol. 10 Ryszard Koziołek: Sienkiewicz's Bodies. Studies of Gender and Violence. Translated by David Malcolm. 2015.

Vol. 11 Wojciech Tygielski: Italians in Early Modern Poland. The Lost Opportunity for Modernization? Translated by Katarzyna Popowicz. 2015.

Vol. 12 Dariusz Jarosz / Maria Pasztor: Polish-French Relations, 1944-1989. Translated by Alex Shannon. 2015.

Vol. 13 Urszula Augustyniak: History of the Polish -Lithuanian Commonwealth. State - Society Culture. 2015.

Vol. 14 Piotr Sobolczyk: Polish Queer Modernism. 2015.

Vol. 15 Jacek Soszyński / Agnieszka Chamera-Nowak (eds.): Book versus Power. Studies in the Relations between Politics and Culture in Polish History. Editorial assistance by Dan Embree. Translated by Jacek Soszyński 2015.

Vol. 16 Wojciech Kriegseisen: Between State and Church. Confessional Relations from Reformation to Enlightenment: Poland - Lithuania - Germany - Netherlands. Translated by Bartosz Wójcik and copy-edited by Alex Shannon. 2016.

Vol. 17 Urszula Sowina: Water, Towns and People. Polish Lands against a European Background until the Mid-16 ${ }^{\text {th }}$ Century. Translated by Justyna Woldańska. 2016.

Vol. 18 Grzegorz Krzywiec: Chauvinism, Polish Style. The Case of Roman Dmowski (Beginnings: 1886-1905). Translated by Jarosław Garliński. 2016.

Vol. 19 Andrzej Sakson: Von Memel bis Allenstein. Die heutigen Bewohner des ehemaligen Ostpreußens: Memelland, Kaliningrader Gebiet, Ermland und Masuren. Übersetzt von Marek Drewnowski. 2016.

Vol. 20 Antoni Mączak: Unequal Friendship. The Patron-Client Relationship in Historical Perspective. Translated by Alex Shannon. 2017.

Vol. 21 Olga Szmidt / Katarzyna Trzeciak (eds.): Face in Trouble - From Physiognomics to Facebook. Copy-edited by Soren Gauger. 2017. 
Vol. 22 Alina Cala: Jew. The Eternal Enemy? The History of Antisemitism in Poland. 2019.

Vol. 23 Agata Brajerska-Mazur / Edyta Chlebowska (eds.): Jew. On Cyprian Norwid. Studies and Essays. Vol. 1: Syntheses. 2019.

Vol. 24 Beata Nowacka / Zygmunt Ziątek: Ryszard Kapuściński. Biographie d'un écrivain. 2019.

Vol. 25 Stanisław Bylina: Religiousness in the Late Middle Ages. Christianity and Traditional Culture in Central and Eastern Europe in the Fourteenth and Fifteenth Centuries. 2019.

www.peterlang.com 